Juliane Cristina De Souza Silva

\title{
A SOBRECARGA SALINA INDUZ A ALTERAÇÕES HEMODINÂMICAS E NO REMODELAMENTO DE MATRIZ EXTRACELULAR VASCULAR EM RATOS NORMOTENSOS
}

Tese apresentada à Faculdade De Medicina da Universidade de São Paulo para obtenção do título de doutora em ciências

Programa de Fisiopatologia Experimental Orientador: Prof ${ }^{a}$ Dra Silvia Lacchini

São Paulo 2019 


\section{Dados Internacionais de Catalogação na Publicação (CIP)}

Preparada pela Biblioteca da

Faculdade de Medicina da Universidade de São Paulo

Creprodução autorizada pelo autor

Silva, Juliane Cristina de Souza

A sobrecarga salina induz a alterações

hemodinâmicas e no remodelamento de matriz

extracelular vascular em ratos normotensos /

Juliane Cristina de Souza Silva. -- São Paulo, 2019.

Tese (doutorado)--Faculdade de Medicina da

Universidade de São Paulo.

Programa de Fisiopatologia Experimental.

Orientadora: Silvia Lacchini.

Descritores: 1.Doenças cardiovasculares 2.Pressão arterial 3.Cloreto de sódio na dieta 4.Matriz

extracelular 5.Artérias 6.Ratos Wistar

$\mathrm{USP} / \mathrm{FM} / \mathrm{DBD}-140 / 19$

Responsável: Erinalva da Conceição Batista, CRB-8 6755 
À Deus.

Que viu em meu coração o sonho, ouviu minhas preces, enxugou minhas lágrimas, me fortaleceu e tornou aquilo que um dia foi sonho, em realidade. 


\section{Agradecimentos}

"Agradecimentos" essa parte da formulação do documento da tese não poderia ter nome melhor. Pois o sentimento que domina meu coração nesse momento é gratidão. É nesse momento em que olhamos pra trás e vemos toda a nossa trajetória e cada pessoa que passou em nosso caminho.

Tudo começou há 12 anos, apaixonada pelas criações de Deus não me contentava com respostas simples, mas queria entender cada detalhe. Cada resposta recebida era seguida de um "por quê?".

O sonho de compreender o funcionamento de cada ser vivo, de responder aos meus "por quês" começou a ser realizado na graduação: Ciências Biológicas. Que curso lindo! Como é maravilhoso poder compreender o surgimento da vida, como ela se desenvolve, e como as muitas vidas (as muitas espécies de vida) se interagem. Mas diferente do que eu imaginava, ao invés de obter respostas, surgiram ainda mais questionamentos. Não somente isso, mas começou a crescer em meu coração o desejo de poder mudar 0 mundo, de fazer a diferença.

Ainda durante a graduação, comecei a ter aulas de Anatomia Humana, Fisiologia Humana e Histologia Humana, com três professoras que levarei para sempre em meu coração e minha memória (Patricia Fiorino, Mirian Ribeiro, Maria Lucila Ribeiro), mais tarde conheci uma mente brilhante na qual também aprendi muito, professora Vera Farah. Cada uma delas abriu minha mente e tocou meu coração de uma forma. A ponto de eu decidir que a área da biologia que eu gostaria de atuar seria a saúde humana.

Em 2008, tive a oportunidade de conhecer aquela que incentiva cada questionamento meu, não somente isso me incentiva a formular hipóteses e querer estudar mais e mais. Minha orientadora, Silvia Lacchini. Lá se vão mais de 10 anos de convivência, tudo o que sou cientificamente devo a você. Inspiro-me na profissional que você é, admiro a mulher sonhadora e forte que hoje tenho como, além de orientadora, minha amiga e madrinha de casamento. Palavras nunca serão suficientes para agradecer o que você fez e faz e, mais ainda o que você representa na minha vida. 
Por meio de você pessoas surgiram em meu caminho, a qual eu serei sempre grata: Katia Viegas (minha amiga e meu anjo doido), quando nos conhecemos eu era apenas uma iniciação cientifica e você estava trabalhando em seu doutorado. Você fez questão que eu te acompanhasse em cada etapa do seu trabalho, sempre que algum experimento dava errado você me fazia pensar no por que, e sempre que dava certo, você me fazia explicar alguma via de ativação ou algo semelhante. Você não sabe o quanto isso me influenciou positivamente, o quanto me tornou critica cientificamente, muito obrigada! Obrigada também pela amizade e por sempre cuidarmos uma da outra. Não posso deixar de estender meu agradecimento ao Miguel, que nesta fase final de experimentos: abriu mão do seu tempo com a mamãe, comeu Mcdonalds durante quase uma semana e perdeu a estreia do filme que tanto ansiava para me emprestar sua mãe e me ajudar com meus experimentos. Que Deus possa recompensá-los por tudo que fizeram por mim, porque eu jamais vou conseguir retribuir.

Juntamente a Silvia e a Katia, não posso deixar de mencionar aquelas que se tornaram minha família científica: Cintia, Rariane, Natalia e a mais recente Vanessa. Quantas histórias temos juntas, quantas risadas, quantas lágrimas, quanta raiva e alegria. Ao escrever esse parágrafo me vem a memória tantos momentos, que poderiam se tornar páginas e páginas. Meu MUITO OBRIGADA pela ajuda durante todo o processo desde o mestrado, sem dúvida eu não teria conseguido sozinha. Foram muitas gaiolas para lavar, muitos animais para tratar, muitas perfusões, muitas lâminas, muitos sábados e domingos trabalhando. Mas, sem dúvida, minha gratidão maior é a amizade que formamos amo muito vocês, minha família USP!

Esse projeto não seria possível também se não fossem nossos parceiros: Laboratório de Hipertensão Experimental (InCor) sob a supervisão da Prof Maria Claudia Irigoyen. Agradeço à professora por ter me recebido, me orientado, me auxiliado e me dado autonomia para trabalhar. Agradeço ao Maikon que tanto me ajudou em diversos procedimentos, esteve trabalhando tão próximo que eu dizia que esse projeto era dele também, pois ele mesmo ao ver os resultados questionava se aquilo era esperado ou não. Ao Oscar e ao Fernando que me auxiliaram na compreensão dos dados hemodinâmicos, a 
Daniela Farah que me auxiliou na compreensão dos dados de fluxo tecidual, ao sr Edson Moreira que cedeu por vezes seu espaço de trabalho e seu tempo para me explicar os procedimentos cirúrgicos e me contar as suas experiências em outros trabalhos. Por fim, ao Prof Cristiano Mostarda, que foi fundamental na análise e interpretação dos dados hemodinâmicos.

Certamente a emoção neste momento me faz esquecer alguns nomes, mas em nada isso interfere na gratidão que tenho a esta equipe de trabalho. $\mathrm{A}$ todos vocês do Laboratório de Hipertensão Experimental, meu muito obrigada!

Ao Laboratório de pesquisa do depto de Farmacologia da USP de Ribeirão Preto, coordenado pela Prof Michele Castro. Que privilégio ter conhecido vocês! Que honra poder compartilhar do mesmo laboratório e aprender novas rotinas e procedimentos, muito obrigada por me fazerem ser uma nova apaixonada pelas metaloproteinases. Prof Michele, Juliana, Atlante e Vanessa, não há palavras para agradecer.

Ao Laboratório de Investigação Médica na Unidade de Biomecânica Vascular na FMUSP. Prof Erasmo, Gina e Alexandre, muito obrigada por toda paciência em me explicar o teste biomecânico, obrigada pelo tempo que dispuseram a me ajudar. Gina, querida, sem palavras para dizer a você. Sempre tão atenciosa, me ajudou tanto! Obrigada pelas conversas, pelas risadas e conselhos.

Sem dúvida ainda há pessoas que não citei o nome, e peço perdão por isso, mas minha gratidão se estende a todos que de alguma forma me ajudaram não somente em meu projeto, mas na construção daquela que sou hoje.

Mas não posso terminar esses agradecimentos sem falar daqueles que são a minha base, minha família. Aos meus pais e minha irmã, sempre me incentivaram a estudar e buscar aquilo que sempre sonhei. Sacrificaram-se por vezes para eu chegar até aqui, abriram mão de estarem comigo por eu ter que ir pra USP trabalhar. Eu não teria chegado aqui se não fosse por vocês. Louvo e agradeço a Deus por me darem uma família tão boa e que reflete amor. Que 
Deus derrame sobre a vida de vocês bençãos incontáveis em retribuição a tudo o que fizeram por mim. Meu amor incondicional e eterno à vocês três.

Finalizando meus agradecimentos, falo daquele que acompanhou meu doutorado desde o início: Guilherme Brito, meu amado esposo. O inicio do doutorado também foi o início de nosso namoro e ao fim do doutorado (que já uma benção), fui abençoada mudando de "namorada" para "esposa". Você nunca me deixou desistir, sempre me inspirou a continuar e ainda inspira. Você me faz querer voar cada vez mais alto e a buscar mais respostas e novos "por quês". Sempre quis saber de cada detalhe da pesquisa, até me ajudar a limpar gaiolas metabólicas uma vez você foi. E sempre falando de mim aos outros com tanto orgulho, palavras que eu nem mereço. Eu te amo tanto que não consigo expressar em palavras. Assim como meus pais e minha irmãzinha, você abriu mão de mim em vários momentos, aguentou minhas explosões e minhas lágrimas sem nunca reclamar. Se cheguei até aqui devo também a você! Eu te amo e sempre amarei! Obrigada meu amor, meu companheiro até o fim! Que Deus te abençoe muito!

E por fim, mas nunca menos importante, à Deus na qual dedico a Ele este trabalho. Pois foi Ele quem moveu as montanhas, que mostrou o caminho, que colocou e tirou pessoas do meu caminho, que me fortaleceu e capacitou. À Deus, minha gratidão. 


\section{Sumário}

$\begin{array}{ll}\text { 1. Introdução } & 01\end{array}$

1.1. Sobrecarga Salina $X$ Mecanismos de regulação da Pressão Arterial 01

1.2. Remodelamento Vascular 05

2. Hipótese 12

3. Objetivos 12

4. Material e Métodos 13

4.1. Animais e Tratamentos 13

4.2. Protocolos Experimentais 14

4.2.1. Avaliação em Gaiola Metabólica 15

4.2.2. Avaliação Hemodinâmica 15

4.2.3. Estudo do Fluxo Tecidual pelo método de Microesferas 17

4.2.4. Estudo da resistência e elasticidade da Aorta pelo Teste Biomecânico 20 Destrutivo Uniaxial

4.2.5. Estudo da atividade das Metaloproteinases por Zimografia em Gel 23

4.2.6. Análise Histológica das Aortas e artérias Mesentéricas 24

4.3. Análise Estatística 30

5. Resultados e Discussão 31

5.1. Caracterização do Modelo 31

5.2. Estudo da Sobrecarga Salina no Controle Hemodinâmico 36

5.2.1. Avaliação da Pressão Arterial Média (PAM), Diastólica (PAD) e 36 Sistólica (PAS)

5.2.2. Estudo da PAS e Variabilidade da PAS 37

5.2.3. Estudo da Frequência Cardíaca (FC) e Intervalo RR 39

5.2.4. Variabilidade da FC no Domínio do Tempo 40

5.2.5. Modulação Simpática e Parassimpática e VLF Absoluta no 42 Domínio da Frequência

5.2.6. Balanço Simpato Vagal 45

5.2.7. Sensibilidade Barorreflexa Espontânea 46

5.2.8. Análise do Débito Cardíaco e Indice Cardíaco 48

5.3. Estudo do Fluxo Tecidual 51

5.4. Estudo Biomecânico da Aorta 52 
5.5. Estudo do Remodelamento Vascular

5.5.1. Remodelamento da parede Aórtica

5.5.2. Contagem das Lamelas Elásticas da Aorta 57

5.5.3. Estudo da Deposição de Colágenos Fibrilares na Aorta 58

5.5.4. Avaliação dos Colágenos não fibrilares na Aorta 60

5.5.5. Estudo do Remodelamento nas artérias Mesentéricas 63

5.5.6. Estudo da Deposição de Colágenos Fibrilares nas artérias 63 Mesentéricas

5.5.7. Avaliação de Colágenos não fibrilares nas artérias Mesentéricas 66

5.5.8. Análise das Metaloproteinases de matriz de parede vascular $\quad 67$

5.5.9. Avaliação de Marcadores Teciduais para Fibrose 70

6. Considerações Finais 76

7. Conclusões 79

8. Referencias Bibliográficas 80

ANEXOS 


\section{RESUMO}

Silva JCS. A sobrecarga salina induz a alterações hemodinâmicas e no remodelamento de matriz extracelular vascular em ratos normotensos [tese]. São Paulo: Faculdade de Medicina, Universidade de São Paulo; 2019.

As doenças cardiovasculares estão entre as principais causas de mortalidade no mundo. Entre estas doenças, a hipertensão arterial tem apresentado um dos índices mais significativos. A hipertensão arterial é uma doença multifatorial e, dentre os fatores desencadeantes, está o consumo excessivo de sal pela população. Segundo a OMS, a ingestão diária de sal por pessoa não deve ultrapassar o limite de $5 \mathrm{~g}$; porém, a maior parte dos países, incluindo o Brasil, ultrapassa o consumo de $10 \mathrm{~g}$ de sal por pessoa por dia. Se considerarmos que o consumo de sal por dia ultrapassa os limites aceitáveis e que grande parte da população não apresenta hipertensão, surge como questionamento de como essa sobrecarga salina se relaciona com o desenvolvimento da hipertensão arterial e quais os mecanismos fisiológicos envolvidos numa fase pré-hipertensiva. Nossa hipótese é a de que a sobrecarga salina induz alterações na regulação hemodinâmica bem como adaptações vasculares independente de alterações na pressão arterial. Para responder nossa hipótese, foram utilizados ratos Wistar machos, distribuídos em três grupos experimentais: 1) controle (Cont), com acesso a água de beber livre de $\mathrm{NaCl}$ ); 2) Sal-2, tratado com $\mathrm{NaCl} 1 \%$ na água de beber por 2 semanas; e 3) Sal-12, tratado com $\mathrm{NaCl} 1 \%$ na água de beber por 12 semanas. Os grupos experimentais foram usados para avaliar o modelo experimental (com acompanhamento de peso corporal e de ingestão de água e exceção de urina em gaiola metabólica), bem como para os estudos propostos: avaliação hemodinâmica (Estudo 1), avalição de fluxo regional (Estudo 2), estudo biomecânico da aorta (Estudo 3), e estudo do remodelamento vascular (Estudo 4). Para estes estudos, foi feita medida da pressão arterial e frequência cardíaca, teste biomecânico da aorta, avaliação de fluxo tecidual, avaliação histológica dos conteúdos de colágeno e lamelas elásticas; estudo de marcadores de fibrose vascular por imunohistoquímica e avaliação de metaloproteinases. Os principais resultados obtidos mostram que a sobrecarga salina não altera a pressão arterial, mas leva ao aumento da atividade simpática e redução da atividade parassimpática, além de reduzir a variabilidade da frequência cardíaca, normalmente relacionada ao aumento de risco cardiovascular. Os resultados indicam uma redução de fluxo tecidual, como no intestino e na aorta, sugerindo que pode haver 
remodelamento vascular reduzindo o aporte sanguíneo nestes tecidos. O estudo do remodelamento vascular sustenta a ideia de que a sobrecarga salina impõe tanto a artérias de condução como de resistência um importante remodelamento, aumentando a deposição de colágenos fibrilares e de colagenos IV e VII (não fibrilares), além de aumentar a marcação positiva para TGF $\beta$ e Galectina 3. Este remodelamento é reforçado pela diferente marcação positiva para MMP-2, enzima importante da degradação da matriz colágena. A sobrecarga salina em períodos mais crônicos (Sal-12) apresenta redução da resistência da parede da aorta no teste biomecânico, sugerindo que o remodelamento observado possa não ser eficiente na manutenção fisiológica da estrutura vascular. Desta forma, mesmo que a sobrecarga salina não induza um efetivo aumento da pressão arterial para se considerar que estes animais normotensos estejam desenvolvendo hipertensão, é evidente seu efeito sobre os mecanismos regulatórios como o sistema nervoso simpático e parassimpático e sobre a estrutura vascular, levando à alteração na deposição de elementos da matriz extracelular e à modificação de suas características mecânicas. Tais características sugerem que a sobrecarga salina crônica está associada ao desenvolvimento de um estado semelhante aos níveis iniciais da hipertensão.

Descritores: Doenças cardiovasculares; Pressão arterial; Cloreto de sódio na dieta; Matriz extracelular; Artérias; Ratos Wistar. 
Silva JCS. The salt overload induces hemodynamic changes and the remodelling of vascular extracellular matrix in normotensal rats [thesis]. São Paulo: "Faculdade de Medicina, Universidade de São Paulo"; 2019.

Cardiovascular diseases are among the leading causes of mortality in the world. Among these diseases, hypertension has presented one of the most significant indexes. Arterial hypertension is a multifactorial disease and among the triggering factors is excessive salt intake by the population. According to $\mathrm{WHO}$, the daily intake of salt per person should not exceed the limit of $5 \mathrm{~g}$; however, most countries, including Brazil, exceed 10 grams of salt per person per day. If we consider that salt intake per day exceeds acceptable limits and that a large part of the population does not present hypertension, it appears as a question of how this saline overload is related to the development of arterial hypertension and which physiological mechanisms involved in a prehypertensive phase. Our hypothesis is that saline overload induces changes in hemodynamic regulation as well as vascular adaptations independent of changes in blood pressure. To answer our hypothesis, we used male Wistar rats, distributed in three experimental groups: 1) control (Cont), with access to drinking water free of $\mathrm{NaCl}$ ); 2) Salt-2, treated with $1 \% \mathrm{NaCl}$ in drinking water for 2 weeks; and 3) Salt-12, treated with $1 \% \mathrm{NaCl}$ in drinking water for 12 weeks. Experimental groups were used to evaluate the experimental model (with monitoring of body weight and water intake and urine exception in metabolic cage), as well as for the proposed studies: hemodynamic evaluation (Study 1), regional flow assessment (Study 2), biomechanical study of the aorta (Study 3), and study of vascular remodeling (Study 4). For these studies, blood pressure and heart rate were measured, aortic biomechanical test, evaluation of tissue flow, histological evaluation of collagen contents and elastic lamellae; study of vascular fibrosis markers by immunohistochemistry and evaluation of metalloproteinases. The main results show that saline overload does not alter blood pressure, but leads to increased sympathetic activity and reduced parasympathetic activity, as well as reducing heart rate variability, usually related to increased cardiovascular risk. The results indicate a reduction of tissue flow, as in the intestine and aorta, suggesting that there may be vascular remodeling reducing the blood supply in these tissues. The study of vascular remodeling supports the idea that saline overload imposes an important remodeling on both the conduction and resistance arteries, increasing the deposition of 
fibrillar collagens and collagens IV and VII (non-fibrillar), besides increasing the positive marking for TGF $\beta$ and Galectin 3. This remodeling is reinforced by the different positive labeling for MMP-2, an important enzyme of collagen matrix degradation. Saline overload in more chronic periods (Salt-12) presents a reduction of aortic wall resistance in the biomechanical test, suggesting that the observed remodeling may not be efficient in the maintenance of the vascular structure. Thus, even if the saline overload does not induce an effective increase in blood pressure to consider that these normotensive animals are developing hypertension, its effect on the regulatory mechanisms such as the sympathetic and parasympathetic nervous system and on the vascular structure is evident, leading to alteration in the deposition of elements of the extracellular matrix and the modification of its mechanical characteristics. Such characteristics suggest that chronic saline overload is associated with the development of a state similar to the initial levels of hypertension.

Descriptors: Cardiovascular diseases; Arterial pressure; Sodium chloride, dietary; Extracellular matrix; Arteries; Rats, Wistar. 


\section{Introdução}

\subsection{Sobrecarga salina e Mecanismos de Regulação da Pressão Arterial}

Além da água, o sódio também é um elemento essencial para a vida. A adaptação dos seres vivos para o ambiente terrestre dependeu da evolução de sistemas que reduzissem a perda destes elementos, seja por meio de urina ou por meio de transpiração (O’DONNEL et al.,2015). A importância destes mecanismos nos mamíferos está no fato de que a deficiência de sódio no organismo resulta, entre outros sintomas, alteração dos mecanismos de polarização e despolarização celular, levando à arritmia, fadiga crônica, transtornos de humor, depressão e uma busca comportamental denominada "apetite ao sódio", entre outros. Por outro lado, o consumo excessivo de sódio na dieta, pode levar ao desenvolvimento de doenças como a hipertensão arterial (CHOI et al.,2015). Portanto, é fundamental que haja um controle preciso e sensível, que garanta a homeostase necessária para a saúde de um ser vivo. Dentre os diversos mecanismos de controle hidroeletrolítico, podemos citar: sistema renina-angiotensina, ocitocina, peptídeo natriurético atrial, sistema nervoso autônomo, entre outros.

A Organização Mundial da Saúde recomenda que o consumo máximo diário seja de até $2000 \mathrm{mg}$ de sódio ou $5 \mathrm{~g}$ de $\mathrm{NaCl}$ por indivíduo. Contudo, devido à industrialização de alimentos e o número crescente em opções em fast-foods, a ingesta de sal tem aumentado exponencialmente, passando a ser, em muitos países, de 9 a 12 g/pessoa/dia (OMS, 2013). Este grande aumento da ingesta de sal é relativamente recente em termos evolutivos, tornando-se um desafio para os sistemas fisiológicos para excretar essas grandes quantidades de sal através dos rins. Os primeiros comentários a respeito dos efeitos do sal sobre a função circulatória e renal foram encontrados em antigos manuscritos chineses (HE et al., 2012; STRAZZULLO et al., 2009).

Nos países ocidentais as relações entre sal e pressão arterial (PA) somente foram reconhecidas a partir do século $X X$, por meio de importantes pesquisas. Coleman e Guyton, em 1969, propuseram uma teoria baseada na sequência de 
eventos verificados quando se produz uma carga de sódio em cães parcialmente nefrectomizados; durante a sobrecarga de sódio, num primeiro momento, haveria um aumento de pressão associado a um aumento de débito cardíaco. Isso provocaria uma alta perfusão tecidual seguida de uma vasoconstrição periférica com função autorreguladora protetora para reduzir o fluxo periférico até os valores normais (COLEMAN; GUYTON, 1969). Estes estudos propuseram que o balanço de sódio após a ingestão de sal é regulada por natriurese no rim. Neste sentido, Cowley demonstrou que variações na ingesta de sal são provavelmente as alterações diárias mais comuns da osmolaridade e relacionou-a à sede, como maneira de excretar o sódio (COWLEY et al., 1983; COWLEY et al., 1986).

O sódio é transportado no plasma, gerando um temporário aumento do volume plasmático, que logo em seguida volta aos níveis normais devido ao mecanismo natriurético renal (GUYTON et al., 1970). Contudo, alguns indivíduos possuem deficiências nesta capacidade de excreção, e a retenção de sódio provoca expansão, não mais temporária, do volume extracelular causando maior débito cardíaco com maior perfusão do tecido. Este fato excede as necessidades metabólicas, resultando em respostas fisiológicas autorreguladoras como vasoconstrição, e aumento da resistência periférica, com consequente aumento de PA (MENETON et al., 2005; WEINBERGER,1996).

Além destes, muitos outros estudos foram realizados demonstrando a relação direta da ingesta de sal e a elevação da PA, sendo que os resultados encontrados mostraram que a alta ingesta de sal é prejudicial à saúde e apresenta consequências distintas, devido à heterogeneidade populacional e/ou ao desenho experimental.

Um importante estudo realizado em humanos foi o INTERSALT, que incluiu 10.079 indivíduos de 52 cidades ao redor do mundo, demonstrando significante relação entre a ingestão de sal e o aumento da PA com a idade. Estimou-se que a ingesão de $6 \mathrm{~g} /$ dia em 30 anos leva a um aumento na pressão arterial sistólica (PAS) de $9 \mathrm{mmHg}$ (INTERSALT COOPERATIVE RESEARCH GROUP, 1988). Em contrapartida, estudos demonstram que a redução da ingesta de sal na dieta poderia levar a uma diminuição dos níveis de PAS, independentemente se o individuo é hipertenso ou normotenso. Efeitos combinados sobre a PA de uma baixa ingestão de sódio e a dieta DASH (Dietary Approaches to Stop Hypertension) foram iguais ou 
maiores do que os efeitos da intervenção de um único medicamento (SAKS et al., 2001).

Além dos estudos relacionando a sobrecarga salina ao aumento da pressão arterial, outros estudos em modelos experimentais normotensos e sal-resistentes têm demonstrado que a sobrecarga salina pode impor ajustes cardiovasculares mesmo sem a hipertensão instaurada. Nesse contexto, a sobrecarga de sal na água de beber a $1 \%$ em ratos, foi capaz de alterar o controle autonômico e aumentar de forma expressiva a variabilidade da pressão arterial (LACCHINI et al., 2001; SIMMONDS et al., 2014). Estudos em camundongos normotensos mostraram que a sobrecarga salina a $1 \%$ não altera a pressão arterial, mas leva a diversas modificações em sistemas de controle cardiovascular, como o sistema renina-angiotensina vascular, além de imporem um remodelamento da parede arterial (SILVA, 2013; LIMA et al., 2015). Dessa forma, a sobrecarga salina mostra- se capaz de induzir remodelamento vascular de forma a aumentar o conteúdo colágeno vascular, compatível com um estado de enrijecimento arterial, mesmo sem o desenvolvimento de hipertensão arterial (SILVA, 2013; GRIGOROVA et al., 2015)

A manutenção dos níveis pressóricos dentro de uma faixa de normalidade depende de variações de débito cardíaco ou da resistência periférica ou ainda, de ambos. Diferentes mecanismos de controle interagem entre si de modo complexo, para garantir a manutenção da pressão arterial em níveis adequados nas mais diversas situações, regulando o calibre e a reatividade vascular, a distribuição de fluido dentro e fora dos vasos e o débito cardíaco (IRIGOYEN et al., 2001).

Acredita-se, portanto, que alterações da PA, como as encontradas na hipertensão ou em outras doenças são resultado da disfunção dos sistemas de controle de pressão arterial. À curto prazo, a PA é regulada pelo sistema nervoso autônomo (SNA), agindo em diferentes regiões do sistema cardiovascular por meio de eferências nervosas simpáticas e parassimpáticas. Trata-se de um mecanismo "rápido" de sensibilidade de alterações e "rápido" em respostas reflexas. Neste caso, os principais receptores reflexos atuantes são: pressoreceptores arteriais, quimiorreceptores arteriais e receptores cardiopulmonares (ABBOUD e THAMES, 1983). Tais respostas reflexas são importantes para a estabilização e manutenção da pressão arterial sistêmica durante diferentes situações fisiológicas (IRIGOYEN e 
KRIEGER, 1998; GRASSI et al., 2016; SALMAN,2016).

O SNA influencia diretamente o sistema cardiovascular, uma vez que tanto a noradrenalina como a acetilcolina, liberadas no coração, modificam o débito cardíaco (por alterar a força de contração das fibras miocárdicas) e a frequência cardíaca. Nos vasos de resistência, a liberação da noradrenalina modifica o estado contrátil do músculo liso vascular, e como consequência, a resistência vascular periférica, garantindo assim o controle momento a momento da PA e a perfusão tecidual necessária (VICTOR e MARK, 1995).

$\mathrm{Na}$ fase inicial da hipertensão arterial, encontramos aumento do tônus simpático, níveis elevados de noradrenalina plasmática e da sua liberação regional; e maior sensibilidade à noradrenalina. Além disso, sabe-se que o sistema simpático pode contribuir para a hipertrofia da parede arterial, auxiliando assim na manutenção da pressão arterial elevada (IRIGOYEN et al.,1991; IRIGOYEN et al.,1995).

Um quadro característico na hipertensão arterial e em outras doenças, como a diabetes mellitus, por exemplo, é a denominada disfunção autonômica (DA). A DA se refere à condição na qual a função autonômica se altera de forma a afetar adversamente a saúde de um indivíduo. No caso de uma destas doenças, o SNA adapta-se a um novo patamar de controle da pressão arterial, desencadeando então uma hiperatividade simpática e redução da atividade parassimpática. Há fortes evidências de que o sistema nervoso simpático desempenha papel fundamental por meio de sua atividade aumentada na gênese e sustentação da hipertensão arterial, bem como que, provavelmente a menor inibição dos centros vasomotores resultantes da adaptação dos pressorreceptores, pode ser responsável pelo aumento da atividade simpática. Além disso, já foi descrito que, a provável diminuição da sensibilidade baroreflexa (disfunção autonômica) seja a principal determinante da maior variabilidade da PA (REIS, 1984; FLORAS et al.,1988; SHEPERD, 1990; IRIGOYEN e KRIEGER, 1998; IRIGOYEN et al.,2001).

Não é apenas o aumento da pressão arterial que leva a consequências adversas à saúde, mas também a variabilidade da PA vem sendo reconhecida como fator de risco importante (GUZZETTI et al., 1988; PARATI et al., 2012). Algumas pesquisas têm mostrado que, independentemente dos níveis médios da PA, a oscilação da PA, seja em um tempo curto ou mais longo, podem estar associados ao 
desenvolvimento, progressão e severidade de doenças cardíacas, vasculares e renais. Portanto, a variabilidade da PA, tem sido estudada como um possível marcador de doenças cardiovasculares (CHARKOUDIAN et al., 2009; IRIGOYEN et al., 2016).

Como já mencionado anteriormente, a influência de fatores ambientais (associados a fatores genéticos) sobre os mecanismos de controle da PA podem gerar aumento de débito cardíaco, que resulta num maior aporte sanguíneo para as artérias e demais vasos. Acredita-se que tal estresse mecânico (alterações de fluxo sanguíneo vascular em resposta a variabilidade da PA) seja o iniciador para alterações de matriz extracelular, como a elastina e as fibras colágenas (CECELJA e CHOWIENCZYK, 2012).

Estas proteínas estruturais da parede arterial são as responsáveis por determinar a rigidez e a capacidade do vaso em se expandir e retornar ao seu estado inicial (recolhimento elástico). O termo "enrijecimento arterial" diz respeito à redução da capacidade da artéria para se expandir e retornar ao estado inicial frente às oscilações da PA. No caso da HA, não há terapia farmacológica que reverta especificamente as alterações em proteínas estruturais e, neste caso, a redução da PA (que é o objetivo dos medicamentos anti-hipertensivos) pode não diminuir tal remodelamento, mantendo altos os riscos de doenças cardiovasculares (CECELJA e CHOWIENCZYK, 2016).

\subsection{Remodelamento Vascular}

Há muitos anos foi descrito que por um motivo que ainda não foi totalmente esclarecido, algumas pessoas (com o passar dos anos e/ou diante de algum estimulo ambiental) não conseguem retornar aos seus níveis basais de pressão arterial, e que, o não retorno também está associado a um aumento progressivo da resistência vascular periférica (FOLKON,1982). Em outras palavras, os mecanismos que promovem desequilíbrio entre os fatores pressores e depressores, induzem alteração do calibre das arteríolas, e portanto, merecem atenção especial.

Eles atuam basicamente na contração da musculatura que regula a luz do vaso ou na espessura da musculatura, aumentando ou reduzindo a luz vascular (KRIEGER et al., 1999; MICHELINI et al., 2008). As adaptações estruturais de pequenas e 
grandes artérias envolvem um processo conhecido como remodelamento vascular. Neste ponto, é importante entender o comportamento diferente destes tipos de artérias em resposta à hipertensão, devendo-se levar em conta suas características estruturais e suas funções.

As artérias apresentam sua parede formada por três túnicas, com particularidades próprias conforme a função desempenhada. Estas túnicas, partindo da luz vascular, são denominadas túnicas íntima, média e adventícia.

A túnica intima apresenta uma camada de epitélio pavimentoso em sua superfície interna, denominada endotélio, associada a um tecido conjuntivo frouxo em maior ou menor quantidade, segundo o calibre do vaso (JUNQUEIRA; CARNEIRO, 2004). Em virtude de sua localização, as células endoteliais servem como sensores biomecânicos que detectam e respondem a alterações no fluxo sanguíneo, tais como a alteração que ocorre após a expansão do volume sanguíneo quando há aumento na ingesta de sal (DAVIES, 1995). Além disso, o endotélio tem um papel importante na troca de moléculas e células entre o sangue e os tecidos, além de produzir fatores vasoativos, como as endotelinas, que são substâncias vasoconstritoras, e o óxido nítrico, que é um importante vasodilatador da musculatura lisa vascular (VIEGAS; LACCHINI, 2008).

Já a túnica média é constituída principalmente por células musculares lisas vasculares (CMLVs) e matriz extracelular (MEC), essencial na regulação da homeostase e arquitetura tecidual (STAMENKOVIC et al., 2003). As CMLVs na média são as responsáveis pela síntese das proteínas da MEC. Esta túnica é importante para a regulação do fluxo sanguíneo, sendo capaz de se distender (até um limite determinado pelo conteúdo colagênico) e de retornar elasticamente ao seu estado anterior (devido à presença das lamelas elásticas), garantindo a manutenção do fluxo de sangue no sistema (VIEGAS; LACCHINI, 2008).

Por último, a túnica adventícia se caracteriza pela presença de tecido conjuntivo, tendo como principal componente os fibroblastos e as proteínas da MEC por eles sintetizadas, especialmente colágeno do tipo I e fibras elásticas. Além disso, em artérias de grande calibre, são encontrados vasos nutrícios (vasa vasorum), tecido adiposo, terminações nervosas, nervos e eventuais células inflamatórias 
(JUNQUEIRA et al., 2005).

O processo de remodelamento vascular é dependente da interação dinâmica entre fatores gerados localmente, substâncias vasoativas e estímulos hemodinâmicos, e pode contribuir para o desenvolvimento de doenças vasculares e desordens circulatórias. Classicamente, o processo se resume a três etapas: 1) detecção de mudanças hemodinâmicas e fatores humorais; 2) sinalização autócrina e parácrina; síntese e liberação ou ativação de substâncias que influenciam o crescimento celular, morte ou migração, ou a composição da matriz extracelular; e 3) mudanças estruturais resultantes na parede vascular (GIMBRONE et al., 1997).

Embora as células das três túnicas que compõem o vaso possam participar do processo de remodelamento, as células endoteliais (CEs) e as células musculares lisas vasculares (CMLVs) têm recebido maior relevância, já que a superfície endotelial está constantemente exposta a fatores humorais, mediadores inflamatórios e forças físicas, e as CMLVs apresentam papel preponderante no controle vasomotor e na síntese de moléculas que compõem grande parte da MEC (WAGENSEIL e MECHAM, 2009). Os processos que envolvem o remodelamento vascular estão relacionados a situações de reparo, inflamação, desenvolvimento ou crescimento (STAMENKOVIC et al., 2003).

Os termos anatômicos macro e microcirculação referem-se a artérias com diferenças tanto estruturais como funcionais. As artérias que compõem a macrocirculação são artérias sistêmicas encontradas a partir do coração a montante dos vasos de resistência, e consistem tanto nas grandes e elásticas artérias proximais como nas artérias médias mais distais e mais musculares. Funcionalmente falando, as artérias da macrocirculação são responsáveis pelo transporte em massa de sangue, oxigênio e nutrientes para todos os órgãos (vasos de condução), além de realizarem o amortecimento das oscilações de pressão sanguínea geradas pela pulsação ventricular durante sístole e diástole (FEIHL et al., 2009; LAURENT E BOUTOUYRIE, 2015).

Já a microcirculação é composta por pequenas artérias (com diâmetro entre 150 e $300 \mu \mathrm{m})$ e arteríolas, caracterizadas pela existência de uma única camada de 
células musculares lisas em sua túnica média (CHRISTENSEN e MULVANY, 2001; FEIHL et al., 2006), além de capilares e vênulas. Funcionalmente, as pequenas artérias que precedem as arteríolas são conhecidas como artérias de resistência. Estas realizam a dissipação da energia potencial do sangue arterial, garantindo que a pressão intracapilar média seja mantida em condições muito restritas, de forma a permitir as trocas normais com o compartimento extravascular, bem como a preservar a integridade estrutural da frágil parede capilar (FEIHL et al., 2009; VAGENSEIL e MECHAM, 2009).

Em condições normais, a perfusão tecidual é garantida pela capacidade dos vasos sanguíneos em adaptar o seu diâmetro, estrutura da parede vascular e a composição desta em resposta a estímulos. Esta adaptação somente é possível graças aos componentes da matriz extracelular vascular que contribuem significativamente para as propriedades físicas (tais como estiramento, contração e compressão) e biológicas que controlam 0 fluxo de sangue aos tecidos (FITZSIMMONS; SHANAHAN, 2002; AKKER, et al.,2010).

A MEC é constituída por numerosas proteínas, sendo as colágenas, seu principal componente, além de diversas outras proteínas como proteoglicanas, glicosaminoglicanas, elastina, laminina e metaloproteases de matriz (VIEGAS; LACCHINI, 2008). Em conjunto, estas constituem um arcabouço que auxilia na manutenção da integridade do tecido, regulação da migração de células e funcionam como um reservatório de citocinas e fatores de crescimento (STAMENKOVIC et al., 2003).

As propriedades elásticas das artérias dependem em grande parte dos componentes da MEC, especialmente elastina e o colágeno, e da organização espacial destes com as células musculares lisas. (GLAGOV et al., 2002). O colágeno é o componente mais abundante da MEC e atua na manutenção da sua integridade e resistência à tensão da parede vascular (PLENZ et al., 2003), formando uma rede de sustentação tanto em vasos sanguíneos de humanos como de outros vertebrados (VIEGAS; LACCHINI, 2001; STHEBENS, 1996). Além do colágeno, outros elementos da MEC interagem com as células adjacentes, como por exemplo, laminina, elastina, fibronectina, tenascina e outras proteínas de adesão e, todos estes, atuam no processo de remodelamento (AKKER, et al.,2010). 
O componente elástico da MEC também é muito importante na composição estrutural dos vasos sanguíneos. Na estrutura de grandes artérias como a aorta, a elastina é o componente principal que responde pela elasticidade e distensão, propriedade fundamental na função cardiovascular, permitindo o fluxo sanguíneo adequado para a irrigação dos órgãos (SONG; ROACH, 1985; JUNQUEIRA; CARNEIRO, 2004; AKKER, et al., 2010).

O reparo e/ou remodelamento constante da MEC envolve quebras de seus componentes por proteases, principalmente a família das metaloproteases (MMPs) (BOSMAN; STAMENKOVIC, 2003; MOTT; WERB, 2004). Na HAS, por exemplo, para que o remodelamento vascular aconteça, este equilíbrio na MEC é quebrado, para que haja uma reorganização que suporte esta nova tensão sanguínea contra a parede dos vasos, assim como as próprias células musculares lisas também acabam por adaptar-se, havendo hipertrofia e/ou hiperplasia celular (CASTRO et al., 2010).

As principais proteínas envolvidas na manutenção da MEC são as metaloproteinases, como já mencionado anteriormente. Trata-se de um grupo de zinco-endopeptidases (contém um sitio catalítico dependente de um metal, no caso, zinco) envolvidas na degradação de componentes da MEC, migração e proliferação de células musculares lisas e invasão de monócitos na túnica íntima (LEMARIÉ et al., 2010; GALIS e KHATRI, 2002; NEWBY, 2006). A participação das metaloproteinases tem sido vista em pesquisas clínicas e em modelos experimentais de hipertensão, assim como, pesquisas envolvendo o estudo do sistema renina angiotensina e estresse oxidativo, e tem mostrado alterações seja em aumento de metaloproteinases ou em diminuição de TIMPs (KANDASAMY et al., 2010).

No sistema cardiovascular (principalmente em modelos de hipertensão) encontramos a presença e atividade de duas principais metaloproteinases: MMP2 e MMP9. Estas são conhecidas também como gelatinases, por degradarem fibras colágenas IV, laminina e elastina (LEMARIÉ et al., 2010). Alguns estudos têm feito algumas associações importantes: pessoas hipertensas, porém com função cardíaca normal, têm perfil normal de MMP/TIMP. Já pessoas hipertensas com disfunção cardíaca, têm alterações de MEC e da razão MMP/TIMP. Neste caso, o aumento de TIMP gera maior probabilidade de desenvolvimento de disfunção cardíaca (AHMED et al., 2006). 
Outros estudos também acreditam que a inibição da atividade de MMP2 reduz o remodelamento vascular induzido pela hipertensão e a consequente disfunção das artérias de condutância e resistência. Entretanto, se de fato é a MMP2 que precede o remodelamento arterial induzido pela hipertensão, isto ainda não está totalmente elucidado. Contudo, já há indicativos de que em modelos de hipertensão secundária (2 rins-1 clipe) a MMP2 seja a principal responsável pelo enrijecimento arterial (BELO et al., 2016).

Diretamente associado ao remodelamento da MEC vascular está o TGF- beta, que atua como uma das principais citocinas profibrogênicas, que em casos patológicos, atua diretamente na produção de fibras colágenas desencadeando processos fibróticos (HAYASHI; SAKAl; 2012). Foi em 1980 que o primeiro membro da família dos TGFs foi descoberto, estas moléculas importantes mostraram ter efeitos complexos no desenvolvimento de órgãos, crescimento e diferenciação celular, mas são particularmente importantes na expressão de proteínas da MEC (BURT,1992).

Além disso, numerosos estudos têm demonstrado que estes fatores de crescimento fibrogênicos participam integralmente na fibrose vascular e renal em uma variedade de doenças (YAMAMOTO, et al.,1993; YAMAMOTO et al., 1994; ZIYADEH et al.,2000; GARCIA-CARDEN et al., 2001; DAHLY et al.,2002; DANIEL et al., 2004). Alguns estudos têm referido que alterações alimentares podem induzir 0 remodelamento da MEC e alterações de resposta vascular a situações de estresse, mesmo sem aumentos da PA. Embora esteja bem estabelecido que o aumento da PA induz remodelamento vascular, o fato de se verificar remodelamento vascular na ausência de hipertensão sugere a possibilidade de que ocorram mudanças estruturais prévias ao estabelecimento de alterações hemodinâmicas. Nesse sentido, Tobian e Hanlon (1990) sugeriram que uma dieta de rica em sal produz lesões arteriais sem aumento da pressão arterial. Além disso, Yu et al.(1998) demonstraram fibrose (enrijecimento) nas artérias, arteríolas, glomérulos e interstício dos corações e rins de ratos normotensos (Wistar-Kyoto) e espontaneamente hipertensos (SHR) alimentados com uma dieta de sal de $8 \%$, correlacionando positivamente com a síntese de TGF $\beta$.

Portanto, resumidamente, o remodelamento arterial ocorre em resposta às mudanças hemodinâmicas, levando a parede arterial a se adaptar à sobrecarga mecânica através da degradação e reorganização da MEC. Pode-se então entenfer 
a existência de uma relação cíclica, onde alterações funcionais levam a modificações estruturais e vice-versa. $O$ entendimento tanto do início do processo hipertensivo como da possibilidade de reversão das alterações geradas pela doença arterial abrem janelas de oportunidades tanto sob o ponto de vista da prevenção como do ponto de vista do tratamento. Pelo que foi abordado previamente, podemos compreender que as alterações vasculares como o enrijecimento arterial, estão intimamente relacionadas ao consumo excessivo de sal, assim como a disfunção autonômica, hipertensão arterial e outras doenças cardiovasculares. 


\section{Hipótese}

Nossa hipótese é de que independentemente da elevação da pressão arterial, o alto consumo de sal pode levar a alterações hemodinâmicas, como uma disfunção autonômica, promovendo o remodelamento de artérias elásticas e musculares e modificando sua matriz extracelular, e que tais alterações podem estar associadas entre si, desencadeando um quadro semelhante ao da pré- hipertensão em humanos.

\section{Objetivos}

Para responder a hipótese formulada, o presente estudo tem os seguintes objetivos:

1. Estudar os efeitos da sobrecarga salina nos mecanismos de regulação da pressão arterial;

2 Entender se a sobrecarga salina leva a alterações de fluxo sanguíneo nos tecidos, especialmente na parede aórtica e no intestino delgado (suprido pelas artérias mesentéricas);

3. Identificar se a sobrecarga salina é capaz de alterar a estrutura da aorta a ponto de modificar a resistência, elasticidade e força de falência do tecido;

4. Verificar se a sobrecarga salina induz remodelamento na parede da aorta e das artérias mesentéricas, especialmente pela avaliação da espessura vascular, da deposição de componentes da matriz extracelular, bem como de mediadores da fibrose vascular. 


\section{Material e métodos}

\subsection{Animais e tratamentos}

Para responder aos objetivos propostos, foram utilizados ratos Wistar, provenientes do Biotério Central da Faculdade de Medicina da USP e mantidos no Biotério da Experimental / InCor, com ciclo claro-escuro de 12 horas, temperatura controlada e livre acesso à água e ração. O protocolo foi aprovado pela CEUA da FMUSP, com número de Protocolo de Pesquisa ํo 183/14.

Os animais foram divididos em grupos gerais e temporais: 2 e 12 semanas (Figura 1). O grupo "Sal 2" recebeu sobrecarga salina em 1\% na água de beber por 2 semanas, já o grupo "Sal 12" recebeu sobrecarga salina em $1 \%$ na água de beber por 12 semanas. Além disso, também tivemos um grupo controle ("Cont") que teve acesso à água livre de $\mathrm{NaCl}$ durante todo o protocolo.

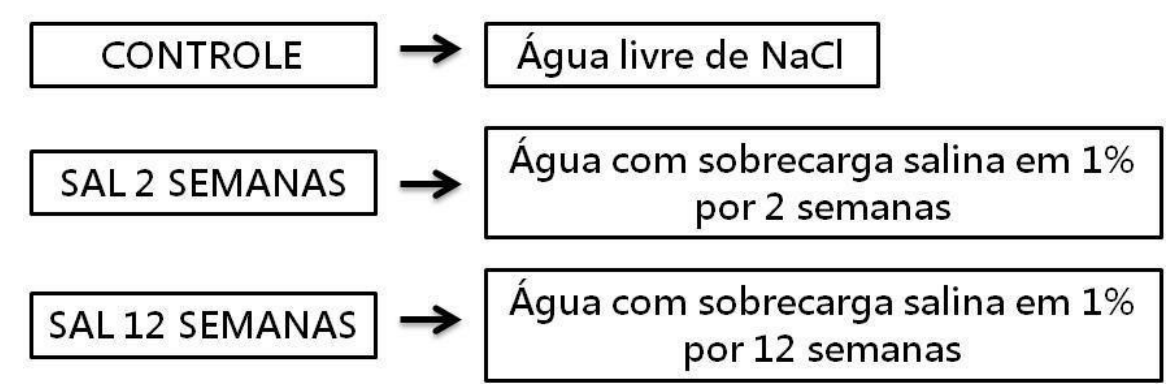

Figura 1 - Grupos experimentais e seus respectivos tratamentos.

Os animais foram separados para o inicio do tratamento, logo após o desmame sendo esta também a idade do inicio do tratamento. No caso dos animais tratados por 2 semanas, esperamos que os mesmos atingissem 14 semanas de idade para dar início ao tratamento propriamente. Este cuidado com a idade dos animais se deu para que todos os animais, independentes de tratados ou não, possuíssem a mesma idade ao final do estudo. 


\subsection{Protocolo Experimental}

Ao longo dos tratamentos, os animais foram pesados semanalmente e a média de consumo de água calculada. Os animais foram submetidos aos mesmos protocolos de tratamento e distribuídos em quatro Estudos Experimentais, de forma a facilitar a análise, apresentação dos resultados e discussão. Assim, os estudos foram distribuídos em:

Estudo 1: Avaliação dos efeitos da sobrecarga salina nos mecanismos de regulação de pressão arterial. Neste estudo, pretende-se cateterizar a artéria femoral para registro de pressão arterial (PA) direta. A partir dos dados obtidos, serão calculadas: PA média, PA diastólica, PA sistólica, variabilidade da PA e da FC, participação simpática e parassimpática sobre o coração e sensibilidade espontânea do reflexo barorreceptor.

Estudo 2: Estudo do fluxo sanguíneo tecidual determinado pela sobrecarga salina. Esta análise usou o método das microesferas, que permite avaliar o fluxo em tecidos específicos. Assim, a ideia é de verificar a perfusão tecidual na parede da própria aorta e na parede do intestino delgado (irrigado pelas artérias mesentéricas)

Estudo 3: Avaliação biomecânica da parede aórtica. Este método biomecânico testa diversas variáveis envolvidas com resistência, espessura, elastificade e falência (rasgadura) do tecido

Estudo 4: Estudo do remodelamento aórtico e das artérias mesentéricas, através de avaliações histológicas da espessura da parede vascular, da análise de compomentes da matriz extracelular, por imunohistoquímica e colorações específicas, bem como a análise da atividade de metaloproteinases seja por zimografia ou imunohistoquímica.

Os grupos de animais tratados foram avaliados para a caracterização do modelo e posteriormente distribuídos em diferentes protocolos como partes de cada um dos 4 estudos executados. Desta forma, a seguir, serão apresentados os métodos empregados. 


\subsubsection{Avaliação em gaiola metabólica}

Assim como em todos os demais protocolos, os animais foram tratados ou não com sobrecarga salina nos tempos de 12 ou 2 semanas. Na última semana de tratamento, os animais foram submetidos à gaiola metabólica, para avaliação precisa do volume ingerido de água e excreção de urina, bem como seu consumo de ração e excreção de fezes. Vale ressaltar que os animais foram mantidos nas gaiolas por $24 \mathrm{hs}$ para sua adaptação ao novo ambiente e somente a partir daí que foi realizada a coleta propriamente dita (de 24 horas).

\subsubsection{Avaliação Hemodinâmica}

Ao final do tratamento com a sobrecarga salina na água de beber, mais precisamente na penúltima semana de tratamento, foi dado início as avaliações hemodinâmicas, a fim de se obter os dados referentes à PA e FC. Ao final das 12 semanas de protocolo experimental, os animais foram eutanasiados para a coleta de tecidos e posterior análise morfológica (Figura 2).

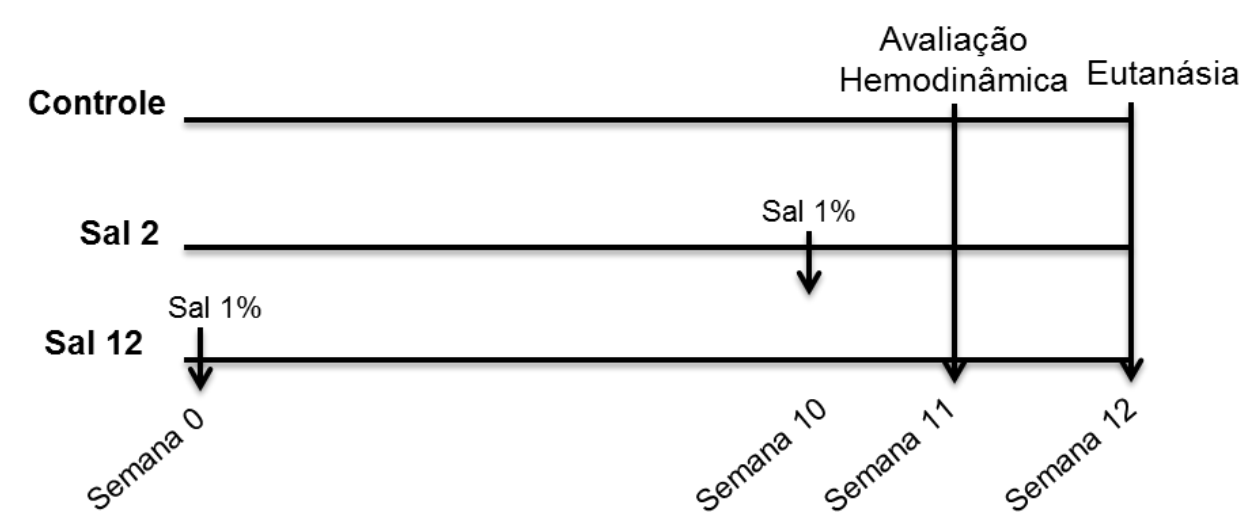

Figura 2: Esquema temporal representando o momento em que ocorre a canulação e medida da pressão arterial momento a momento.

Para a obtenção de dados de PA e FC, os animais foram anestesiados com gás isoflurano na concentração de $1 \mathrm{ml} / \mathrm{ml}$ a $2,5 \%$ (Cristália, $\mathrm{Br}$ ), e colocados em decúbito dorsal para a realização de uma pequena incisão na região inguinal por onde foram implantados cateteres, confeccionados com tubos 
de Micro-Renathane (MRE-025 com diâmetro externo de 0,61 mm e diâmetro interno de $0,28 \mathrm{~mm}$, Braintree Scientific) e Policloreto de Vinila (Abbott), equivalente ao polietileno PE50, esticados em ar quente e preenchidos com soro fisiológico e ocluídos com pinos de aço inoxidável.

Os cateteres foram posicionados no interior da artéria e veia femorais para registro da PA, FC e administração de drogas, respectivamente. Após o implante, os catéteres foram exteriorizados no dorso do animal na região cervical e fixados com fio de algodão na pele (LACCHINI et al., 2001). Todos os procedimentos cirúrgicos foram realizados em condições assépticas, sob visão de um microscópio cirúrgico (DF Vasconcelos modelo MCM 5, São Paulo). Ao término da cirurgia, os animais receberam uma injeção intramuscular de $107 \mathrm{U} / \mathrm{Kg}$ penicilina $\mathrm{G}$ (Benzetacil, FontouraWyeth) e analgésico ( $0,35 \mathrm{~g} / \mathrm{kg}$ de Dipirona Sódica). Os cuidados pós- operatórios foram baseados na descrição de LILES \& FLECKNELL em 1992.

Os registros da PA e FC de repouso foram realizados 24h após a canulação com os animais acordados. Para a realização das avaliações hemodinâmicas sistêmicas, a cânula arterial foi conectada a uma extensão de $20 \mathrm{~cm}$ (PE-50), permitindo livre movimentação do animal pela caixa, durante todo o período do experimento. Esta extensão foi conectada a um transdutor eletromagnético (Kent Instruments, EUA) que, por sua vez, estava conectado a um pré-amplificador (Stemtech, EUA). Sinais de pressão arterial foram gravados durante um período de 30 minutos em um microcomputador equipado com um sistema de aquisição de dados (Windaq, DATAQ Instruments, Akron, OH, EUA), permitindo análise dos pulsos de pressão, batimento-a-batimento, com uma frequência de amostragem de $2000 \mathrm{~Hz}$ por canal, para estudo dos valores de pressão arterial sistólica (PAS), pressão arterial diastólica (PAD), pressão arterial média (PAM) e frequência cardíaca $(F C)$. Os valores de frequência cardíaca foram derivados do sinal pulsátil da pressão arterial. 


\subsubsection{Estudo do fluxo tecidual pelo método das microesferas}

Assim como nos protocolos anteriores, os animais foram tratados ou não com sobrecarga salina nos tempos de 12 ou 2 semanas e, ao final do protocolo, os animais foram eutanasiados da mesma forma. Ao final de todo o protocolo experimental, deuse início às avaliações de fluxo tecidual (Figura 3).

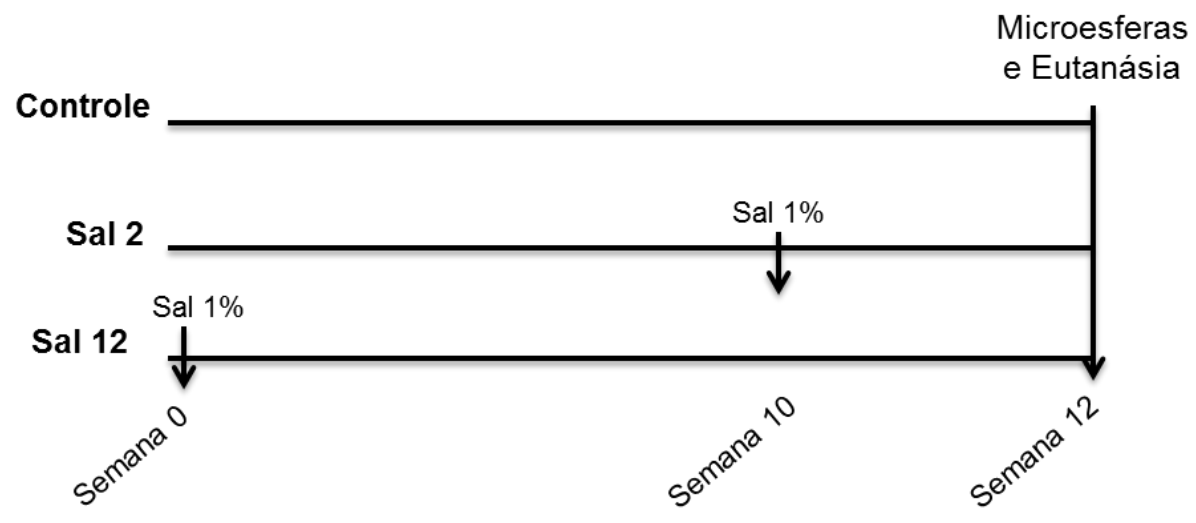

Figura 3: Esquema temporal representando o momento em que ocorreu a aplicação do método das microesferas (ao final dos tempos experimantais..

Esta técnica tem por objetivo avaliar o fluxo sanguíneo em determinada região ou órgão de interesse em ratos. Foi padronizada a partir dos experimentos de Hakkinen (1995), na qual são infundidas na circulação sanguínea do animal, microesferas coloridas. Os tecidos perfundidos com tais microesferas são coletados e digeridos com hidróxido de sódio, a partir daí, uma série de preparações são realizadas até que por fim, o homogenizado é levado ao espectofotômetro e a absorbância liberada pelas microesferas, é lida.

Este protocolo foi realizado ao final de cada tratamento, como descrito a seguir: os animais foram anestesiados com ketamina e xilasina e um catéter de polietileno P50 foi utilizado para a cateterização do ventrículo esquerdo via artéria carótida direita. 0 cateter foi inserido até o ventrículo e sua posição determinada pela observação da característica onda de pressão ventricular. Sinais de pressão ventricular esquerda foram gravados durante um período de 5 minutos em um microcomputador equipado 
com um sistema de aquisição de dados (WINDAQ, DATAQ Instruments, Akron, $\mathrm{OH}$, EUA), permitindo análise dos pulsos de pressão, batimento-a-batimento, com uma frequência de amostragem de $2000 \mathrm{~Hz}$ por canal, para estudo dos valores de máxima pressão sistólica ventricular, pressão diastólica final e derivadas de contração e relaxamento do ventrículo esquerdo.

A análise foi feita utilizando-se programa comercial associado ao sistema de aquisição. As planilhas de dados obtidas foram analisadas em programa comercial para análise (Excel), onde se calculou a média e desvio padrão da $+\mathrm{dP} / \mathrm{dt}$ e da $-\mathrm{dP} / \mathrm{dt}$ para cada animal. A máxima pressão ventricular sistólica foi determinada utilizando-se programa que permite a detecção de máximos e mínimos da curva de pressão batimento a batimento, fornecendo os valores de pressão ventricular sistólica (PSVE). A pressão diastólica final (PDF) foi determinada pela detecção manual do ponto de inflexão no traçado da onda de pressão diastólica do ventrículo esquerdo. Foram realizadas no mínimo 20 deteç̧ões por registro.

Para determinação do fluxo sanguíneo foram utilizadas microesferas coloridas amarelas (Dye-Trak microespheres, Triton Technology). As microesferas são compostas de poliestireno (98\%) e divinilbenzeno (2\%) tendo diâmetro de 15,1 \pm $0,2 \mathrm{~mm}$ e concentração comercial de 3000 esferas $/ \mathrm{mL}$. Após o registro de PA foi injetada uma solução contendo 300.000 esferas $/ 180 \mathrm{~mL}$ sonicadas durante 2 minutos imediatamente antes da infusão. Esta solução $(180 \mathrm{~mL}$ ) foi colocada em $75 \mathrm{~cm}$ de uma extensão de catéter P50 conectada a uma seringa de $1 \mathrm{~mL}$ com salina pré-aquecida $\left(37^{\circ} \mathrm{C}\right)$ contendo Tween $80(0,01 \%)$. A cânula posicionada na aorta abdominal foi conectada a uma seringa de $1 \mathrm{~mL}$, pré-heparinizada, para retirada de sangue durante a infusão.

Dez segundos, antes da injeção das esferas inicia-se a retirada de sangue através de uma bomba de retirada a um fluxo de $0,5 \mathrm{~mL} / \mathrm{min}$ que continua por 75 segundos. São injetadas 300.000 esferas (amarelas) no ventrículo esquerdo a um fluxo de $0,36 \mathrm{~mL} / \mathrm{min}$ durante 50 segundos. Desta forma, os $180 \mu \mathrm{L}$ de solução contendo as microesferas foram injetadas nos primeiros 30 segundos.

O volume de sangue retirado foi reposto através do volume injetado durante a infusão das esferas e por um pequeno volume de salina $(0,1-0,2 \mathrm{~mL})$ injetado in bolus logo após o término do procedimento. 
O animal foi eutanasiado em seguida com overdose de ketamina e xilasina, injetado pela cânula femural e os tecidos foram retirados para análise (cérebro, musculo gastro, rim direito, rim esquerdo, pulmão direito, pulmão esquerdo, intestino delgado, coração, aorta).

As amostras de sangue foram pesadas e colocou-se em tubos de poliproprileno e centrifugadas por 10 minutos, para em seguida ser adicionado reagente de hemólise ao pellet. Os tecidos também foram processados segundo técnica adaptada de Hakkinen et al, 1995.

Para a leitura das microesferas, colocou-se $200 \mathrm{~mL}$ de cada amostra em uma cubeta de quartzo de $180 \mu \mathrm{L}$ (Sigmaâ) e realizou-se a leitura das absorbâncias no espectrofotômetro (Beckman, modelo: DU640). Os picos dos espectros de absorbância das microesferas amarelas foram usados a uma largura de banda de luz $<1,8 \mathrm{~nm}$. A absorbância mínima aceitável foi de 0,02 AU para as amarelas. Absorbâncias menores que estas foram excluídas da análise.

O volume de sangue coletado foi calculado da seguinte forma: peso da amostra de sangue / 1,05 g/mL (valor da constante gravitacional específica do sangue).

A constante de retirada do sangue $(\mathrm{mL} / \mathrm{min})$ foi determinada pelo: volume de sangue $(\mathrm{mL}$ ) coletado / tempo (em minutos) de retirada da amostra. Para cada infusão, o cociente da divisão da constate de retirada do sangue pela $A U$ da amostra de sangue foi utilizado como base para calcular o fluxo para os tecidos: $Q t=A t(Q s / A s)$. Onde, Qt e Qs são fluxos para o tecido ou sangue, e At e As são as absorbâncias do tecido ou do sangue, respectivamente.

Os fluxos sanguíneos foram divididos pelo peso das amostras $(\mathrm{g})$ para obter o fluxo em $\mathrm{mL} / \mathrm{min} / \mathrm{g}$ de tecido. $O$ débito cardíaco, expresso em $\mathrm{mL} / \mathrm{min}$, foi calculado segundo a fórmula:

DC = número total de microesferas injetadas (300.000) X fluxo de referência $(0,5 \mathrm{~mL} / \mathrm{min}) /$ número de microesferas no sangue. Já o índice cardíaco foi obtido: IC= débito cardíaco ( $\mathrm{mL} / \mathrm{min}$ ) / pelo peso corporal do animal, sendo expresso em $\mathrm{mL} / \mathrm{min} / \mathrm{g}$. 
4.2.4. Estudo da resistência e elasticidade da aorta pelo teste biomecânico destrutivo uniaxial

Para este método, os animais foram tratados ou não com sobrecarga salina nos tempos de 12 ou 2 semanas e, a final do tempo de tratamento, foram eutanasiados com sobrecarga de anestésico, sendo as aortas retiradas para a realização do teste biomecânico (Figura 4).

Os demais tecidos foram coletados para o desenvolvimento de um estudo de iniciação científica.

Eutanásia e

Teste Biomecânico

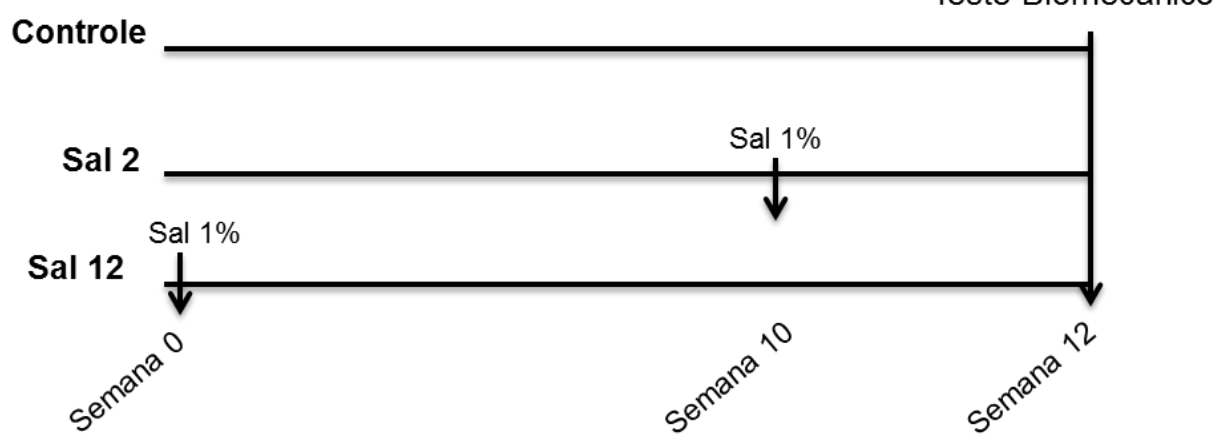

Figura 4: Esquema temporal apresentando o momento em que ocorre a coleta das aortas e o teste biomecâmico

O método utilizado neste estudo (biomecânico) foi desenvolvido pelos pesquisadores do Laboratório de Biomecânica Vascular, do Departamento de Cirurgia da Faculdade de Medicina da Universidade de São Paulo (USP). De cada animal, foi removida a aorta torácida, seguida da dissecção cirúrgica cuidadosa da aorta em bancada, com remoção dos tecidos periaórticos. Após, a aorta foi imersa em solução de cloreto de sódio a $0,9 \%$, à temperatura ambiente.

O teste biomecânico foi realizado 24 horas logo após a preparação da aorta ou no período máximo de 48 horas após a eutanásia. Neste caso, a peça foi mantida em 
refrigeração a $4^{\circ} \mathrm{C}$ e depois deixada à temperatura ambiente para atingir o equilíbrio térmico antes do teste. Não foram utilizadas soluções conservantes nem durante a eutanásia e nem após.

De início, cada aorta de formato retangular, foi fixado ao sistema em suas extremidades por garras delicadas, confeccionadas para firme preensão sem causar dano excessivo ao material. Um sistema regulável permitiu maior ou menor compressão de acordo com as características variáveis de cada vaso, como espessura da parede ou presença de placas ateroscleróticas.

Para o início comum de todos os testes, tendo a mesma força aplicada a todos as arterias, o primeiro passo foi provocar um deslocamento inicial do vaso até manter uma tensão de 0,01 Newton $(\mathrm{N})$, eliminando a ocorrência de dobras macroscópicas. A partir deste ponto, foram aferidas manualmente com um paquímetro digital (Starrett, Brasil), em milímetros, três medidas de largura, de espessura e de comprimento útil do corpo de prova e as médias dos valores inseridas no programa In-Spec PDA do palmtop. O aparelho de teste In-Spec 2200 foi construído de forma personalizada, permitindo o fechamento de um compartimento cúbico e execução do teste com o vaso submerso em solução de cloreto de sódio a $0,9 \%$, à temperatura ambiente.

Na primeira fase da análise biomecânica, cada artéria foi submetida a um préteste, com o objetivo de estabilizar o comportamento mecânico do material e diminuir o efeito de histerese, iniciando o teste em condições semelhantes para todos os espécimes. Este pré-condicionamento foi feito com dez ciclos de distensão e relaxamento, correspondentes a uma distensão de $5 \%$ do comprimento útil do vaso, com uma velocidade de $20 \%$ do comprimento útil por minuto. Esta padronização foi descrita anteriormente por Raghavan et al, em 1996.

Após o pré-teste, realizou-se o teste biomecânico destrutivo até a ruptura total da artéria, com uma velocidade de deslocamento de $20 \%$ do seu comprimento útil por minuto. Os testes foram considerados inválidos quando ocorria o escorregamento da artéria das garras ou ruptura dela com menos de $2 \mathrm{~mm}$ de distância das garras durante a execução do teste. 
A figura 5 representa didaticamente 0 procedimento da técnica. $O$ gráfico representa a força aplicada para o estiramento do vaso até seu ponto de ruptura (falência), as imagens abaixo correspondem a cada etapa de estiramento da aorta mostrado na curva.

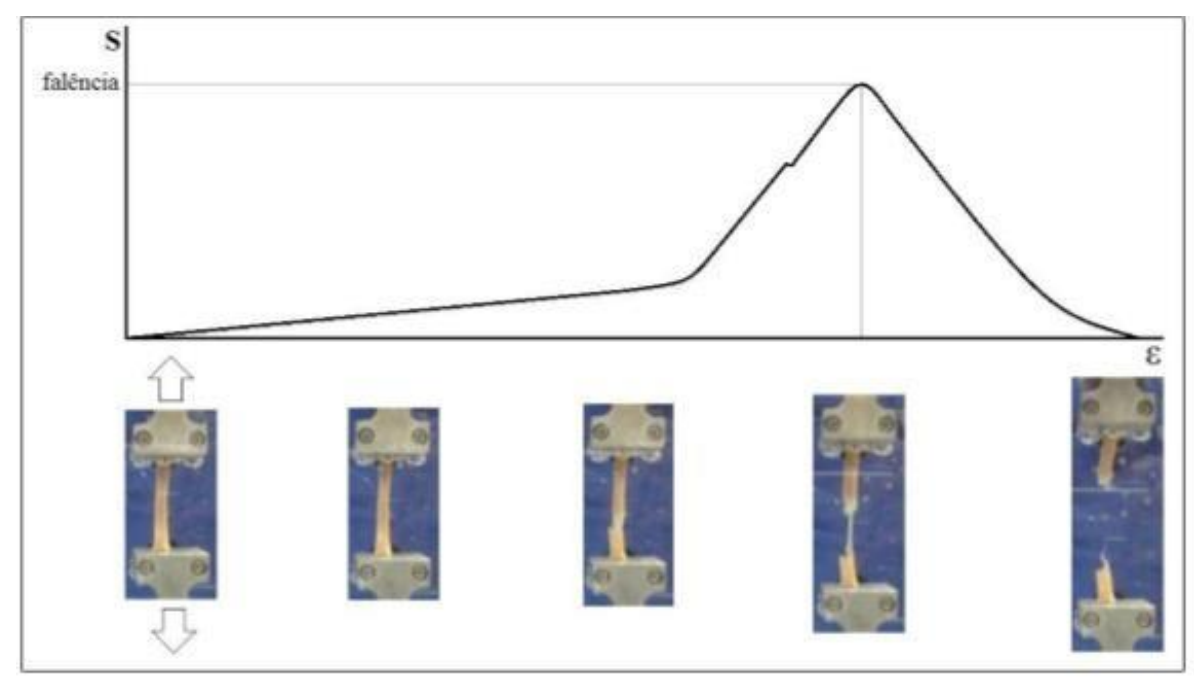

Figura 5 - llustração mostrando a sequência do teste de distensão uniaxial (em cores) com a correspondente curva elástica. $\varepsilon$, deformação; $\mathrm{S}$, estresse

Os dados contínuos das forças aplicadas e das extensões obtidas até a ruptura do material foram automaticamente armazenados no computador e transferidos para uma planilha eletrônica Microsoft Excel (Microsoft, Redmond, Estados Unidos).

Em cada artéria, foram medidos: diâmetro (em $\mathrm{mm}$ ); comprimento, largura e espessura (em $\mathrm{mm}$ ). Os parâmetros de resistência medidos foram: força máxima aplicada até a ruptura do vaso (em $\mathrm{N}$ ); estresse de falência (força dividida pela área da secção transversa do vaso em N/cm2); tensão de falência (força dividida pela largura do espécime, em $\mathrm{N} / \mathrm{cm}$ ); energia de deformação (energia acumulada pelo espécime até a ruptura, em $\mathrm{N} / \mathrm{cm} 2$ ). $\mathrm{O}$ parâmetro de elasticidade medido foi: deformação máxima até a ruptura.

A figura 6 ilustra a parede de um vaso com suas respectivas fibras elásticas e colágenas, e como elas se comportam diante da força exercida pelo teste 
biomecânico. Quanto mais deslocada a curva para a direita, maior a proporção de componentes elástico, quanto mais alto o pico, mais resistente a ruptura ele se apresenta, sendo indicativo aos componentes colágenos.

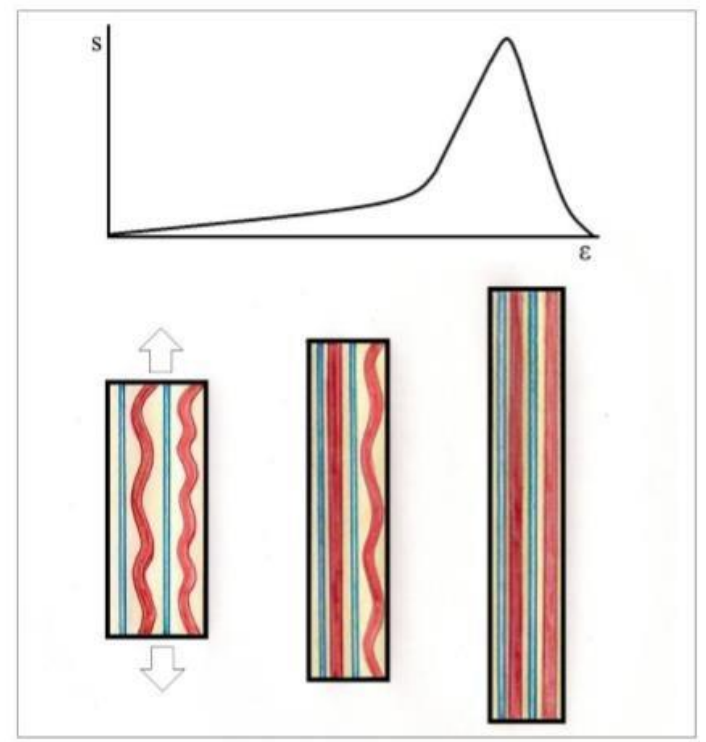

Figura 6 - llustração mostrando a relação das fases do diagrama com a extensão das fibras elásticas (azul) e colágenas (vermelho) durante o teste biomecânico. $\varepsilon$, deformação; $S$, estresse.

\subsubsection{Estudo da atividade das metaloproteinases por zimografia em gel}

Ao final do tempo de tratamento, os animais foram da mesma forma, eutanasiados com sobrecarga de anestésico. Os tecidos foram coletados e congelados em nitrogênio líquido para a avaliação proteica desejada. A zimografia em gel é uma técnica utilizada para avaliar a atividade das gelatinases, como a MMP-2.

O princípio do método baseia-se no fato da MMP-2 degradar a gelatina do gel durante a eletroforese. As amostras previamente preparadas (SDS 2\%, Tris- $\mathrm{HCl} 125$ $\mathrm{mM}$, glicerol $10 \%$ e azul de bromofenol 0,001\%) foram aplicadas em géis de poliacrilamida $12 \%$ e separadas por eletroforese, conforme a técnica de SDS- PAGE. Após este processo, os géis foram submetidos a dois banhos de Triton X-100 a 2\%, 
para remoção do SDS, e foram colocados em solução Tris-CaCl2 $50 \mathrm{mmol} / \mathrm{L}$, por 16 horas, a $37^{\circ} \mathrm{C}$. Posteriormente, foram fixados e corados em solução Coommassie Blue 0,05\% por, no mínimo, 1 hora.

Para visualização das bandas referentes à MMP-2, os géis foram descorados com metanol a 30\% e ácido acético 10\%. Observou-se a formação de bandas claras contra o fundo azul escuro do Coommassie (devido à degradação da gelatina incorporada ao gel). Para cada gel foi utilizado um controle positivo para gelatinases (soro fetal bovino $2 \%$ ). Por ele, foi possível normalizar as quantidades de proteínas obtidas entre os géis, podendo compará-los entre si. A quantificação das bandas de MMP-2 foi feita por meio do software Image J. A MMP-2 foi identificada por meio dos seus pesos moleculares: 72 e $64 \mathrm{KDa}$.

\subsubsection{Análise histológica das aortas e artérias mesentéricas}

Ao final das 16 semanas de vida e após a aferição de pressão, os animais foram submetidos a eutanásia com sobrecarga de anestésico por meio de uma injeção intraperitoneal de ketamina $(100 \mathrm{mg} / \mathrm{kg})$ e xylazina $(20 \mathrm{mg} / \mathrm{kg})$. Após a parada respiratória, foi feita toracotomia e exposição do coração. Posteriormente, foi feita a perfusão pelo ventrículo esquerdo com solução salina, seguida por formol 4\% tamponado, a fim de lavar o sangue dos tecidos e promover melhor fixação para avaliação histológica. Após a coleta, os tecidos foram mantidos em formol 4\% tamponado por mais 24 horas. Os tecidos coletados foram: coração, aorta, artéria carótida, artéria femoral, artéria renal e artéria mesentérica, sendo usados no estudo os resultados obtidos em aorta e artérias mesentéricas..

\section{Análise morfológica - Microscopia de luz}

Após a coleta e perfusão, os tecidos foram fixados em formol 4\% tamponado em PBS, processados e posteriormente incluídos em paraplast. Os tecidos foram 
cortados a $5 \mu \mathrm{m}$ e as lâminas foram coradas. Foram realizadas 2 colorações: Picrossirius red, a fim de serem avaliadas as fibras colágenas perivasculares, em sua deposição morfológica em campo claro, assim como na quantificação das espessuras das fibras colágenas por meio de luz polarizada e Verhoeff Van Gienson, a fim de serem avaliadas a fibras elásticas encontradas na camada média dos vasos.

Identificação de colágenos, MMPs e mediadores do remodelamento vascular por imunihistoquímica (IHQ)

A utilização da coloração de picrossirius red e visualização em luz polarizada nos permite observar a espessura das fibras colágenas perivasculares ali depositadas. Porém, para que pudéssemos obter um resultado mais fidedigno, fizemos uso de imunohistoquímica para a identificação de colágenos IV e VII, principais fibras encontradas em processos de remodelamento vascular.

Devido à importância das funções básicas das proteínas de matriz extracelular (MEC) vascular (Tabela 1), também foi realizada a técnica de Imunohistoquímica para investigar marcações para Metaloproteinase (MMP) do tipo 2, Fator de crescimento transformante (TGF- $\beta$ ) e Galectina 3 (Gal 3) 
Tabela 1 - Proteínas da MEC vascular estudadas por imunohistoquímica e suas respectivas funções básicas *

Fibras finas que interagem com a laminina da membrana basal que sustenta o endotélio e COL IV também interage com receptores de membrana (ex. integrinas).

COL VII

Formam fibrilas que ancoram as fibras de colágeno tipo I à lâmina basal.

MMP-2

Importante

na clivagem de elastina, fibronectina, colágeno e laminina.

\section{TGF- $\beta$}

Atua como um fator antiproliferativo em células epiteliais normais.

GALECTINA 3

Atua na ligação da laminina com a membrana basal

*Alberts, et al. 2011. Biologia Molecular da Célula. $5^{\mathrm{a}}$ ed. Artmed.

Para este estudo, cortes histológicos de $4 \mu \mathrm{m}$ obtidos de aorta e artérias mesentéricas fixados em formol a 4\% tamponado foram dispostos em lâminas silanizadas de acordo como mostrado na Figura 3. O processo de silanização permite que os cortes histológicos fiquem mais fortemente aderidos à lâmina. Os cortes foram então submetidos à desparafinização e hidratação em série de alcoóis de concentração decrescente e água destilada. Em seguida foi feita a recuperação antigênica que consiste em métodos induzidos pelo calor [Heat Induced Epitope Retrieval (HIER)] de resgate do sítio antigênico, ou seja, expõe o antígeno que se deseja estudar e facilita a ligação deste com o anticorpo específico. 
Na recuperação antigênica, a substância tampão apropriada para cada proteína de interesse (Tabela 2) é colocada em recipiente próprio e levado ao banho-maria até que o tampão atinja a temperatura de $98^{\circ} \mathrm{C}$. Então, os cortes foram colocados em suportes e estes, na substância tampão aquecida permanecendo nesta por 20 minutos. Após isso, o recipiente foi retirado do banho e deixado na bancada para esfriar até que atingisse a temperatura ambiente. Daí seguiu-se o procedimento de imuhistoquímica como descrito a seguir.

O método de IHQ utilizado foi o tipo A-B-C (Estreptoavidina - Biotina Peroxidase). $\mathrm{O}$ bloqueio de peroxidase endógena foi feito $\mathrm{com} \mathrm{H}_{2} \mathrm{O}_{2}$ a $3 \%$. Os tecidos foram incubados a temperatura de $4^{\circ} \mathrm{C}$ com anticorpos primários (Ac $1^{\circ}$ ), diluídos em um bloqueador (BSA - Albumina de Soro Bovino) a 3\% por 16-18 horas (overnight).

O estudo imunohistoquímico dos componentes da matriz extracelular (MEC) vascular foi feito usando-se os anticorpos primários, recuperação antigênica e diluições descritos na Tabela 2.

Após a recuperação antigênica e incubação overnight com o anticorpo primário (Ac $1^{\circ}$ ), seguiu-se a incubação com o anticorpo secundário (Ac $2^{\circ}$ ) de acordo com a Tabela 3.

Após a incubação com $\circ$ Ac $2^{\circ}$, seguiu-se a marcação com estreptoavidina conjugada com HRP. Em seguida, fez-se a revelação da marcação, usando DAB (3,3 diaminobenzidina) como cromógeno [Kit DAB Substrate for Peroxidase (Vector®)] e a contracoloração com Hematoxilina. Os controles negativos das reações foram feitos omitindo-se o $A c 1^{\circ}$ no primeiro corte de cada lâmina (Figura 4).

Após a montagem das lâminas estas foram avaliadas em microscópio de forma semi-quantitativa usando um escore de marcação de acordo com a intensidade da coloração marrom obtida com o cromógeno DAB (Tabela 4). 
Tabela 2 - Anticorpos, recuperação antigênica e diluições utilizadas para marcação imunoquistoquímica de proteínas da MEC vascular

\begin{tabular}{|c|c|c|c|c|c|}
\hline Anticorpo & Espécie & Recuperação & Concentração & Diluiç̧ão & Fabricante \\
\hline $\begin{array}{l}\text { Primário } \\
\left(\text { (Ac1ํ) }^{\circ}\right.\end{array}$ & do $A c 1^{\circ}$ & Antigênica & do Anticorpo & para IHQ & \\
\hline Colágeno IV & Rabbit & Tampão Citrato pH 6,0 & {$[1 \mathrm{mg} / \mathrm{ml}]$} & $1: 100$ & $\begin{array}{c}\text { Chemicon } \\
\text { International }{ }^{\circledR}\end{array}$ \\
\hline Colágeno VII & Mouse & $\begin{array}{c}\text { Tampão Tris Citrato pH } \\
7,2\end{array}$ & {$[0.1 \mathrm{mg} / \mathrm{ml}]$} & $1: 100$ & $\begin{array}{c}\text { Chemicon } \\
\text { International® }\end{array}$ \\
\hline MMP-2 & Rabbit & Tampão EDTA pH 8,0 & {$[1 \mathrm{mg} / \mathrm{ml}]$} & $1: 100$ & $\begin{array}{c}\text { Chemicon } \\
\text { International } \AA\end{array}$ \\
\hline TGF- $\beta$ & Rabbit & Tampão tris citrato $\mathrm{pH} 7,2$ & {$[1 \mathrm{mg} / \mathrm{ml}]$} & $1: 100$ & $\begin{array}{c}\text { Chemicon } \\
\text { International® }\end{array}$ \\
\hline Galectina 3 & Hibridoma & Tampão EDTA pH 8,0 & - & $1: 50$ & $\begin{array}{c}\text { Gentilmente doado } \\
\text { pelo Prof Roger } \\
\text { Chammas }\end{array}$ \\
\hline
\end{tabular}


Tabela 3 - Anticorpos secundários (Ac $2^{\text {ario})}$ utilizados na imunohistoquímica

\begin{tabular}{|c|c|c|c|c|}
\hline $\operatorname{Ac}^{\circ}{ }^{\circ}$ & $A C 2^{\circ}$ & $\begin{array}{l}\text { Concentração do } \\
\text { Anticorpo }\end{array}$ & $\begin{array}{c}\text { Diluição do Ac2 para } \\
\text { IHQ }\end{array}$ & Fabricante \\
\hline Colágeno IV & $\begin{array}{l}\text { Mouse anti- } \\
\text { rabbit }\end{array}$ & {$[2-10 \mu \mathrm{g} / \mathrm{ml}]$} & $1: 1000$ & Vector® \\
\hline Colágeno VII & Anti-mouse & {$[2-10 \mu \mathrm{g} / \mathrm{ml}]$} & $1: 1000$ & Vector® \\
\hline MMP-2 & Anti-mouse & {$[2-10 \mu \mathrm{g} / \mathrm{ml}]$} & $1: 1000$ & Vector ${ }^{\circledR}$ \\
\hline TGF- $\beta$ & $\begin{array}{l}\text { Mouse anti- } \\
\text { rabbit }\end{array}$ & {$[2-10 \mu \mathrm{g} / \mathrm{ml}]$} & $1: 1000$ & Vector® \\
\hline Galectina 3 & Anti-mouse & {$[2-10 \mu \mathrm{g} / \mathrm{ml}]$} & $1: 1000$ & Vector® \\
\hline
\end{tabular}

Tabela 4 - Descrição do significado do escore usado para a marcação imunohistoquímica

\begin{tabular}{cc}
\hline ESCORE & SIGNIFICADO \\
\hline 0 & Nenhuma Marcação \\
1 & Marcação leve \\
2 & Marcação entre leve e moderada \\
3 & Marcação Moderada \\
4 & Marcação Intensa \\
\hline
\end{tabular}




\subsection{Análise Estatística}

Os resultados serão apresentados como média „DPM. Os resultados foram submetidos a análise de variância (ANOVA) de um fator (tratamento com sobrecarga salina), complementado pelo teste de Bonferroni. Serão consideradossignificantes valores com $p \leq 0,05$. O software usado para as avaliação foi o programa GraphPad Prism, versão 5.01 (GraphPad Software, Inc., 2007). 


\section{Resultados e Discussão}

A fim de facilitar a discussão e compreensão dos dados, os resultados serão apresentados de acordo com os objetivos propostos. Cada figura de resultado apresentado terá uma interpretação breve e, ao final de cada tópico, será feira uma discussão do mesmo.

\subsection{Caracterização do modelo:}

Muitos pesquisadores têm se preocupado em entender melhor a relação entre o aporte de sal com o aumento da pressão arterial. Para isso, faz-se uso de animais sal-sensíveis (DOCA-sal, por exemplo), animais geneticamente modificados, ou ainda do aumento do teor de sódio na alimentação, geralmente 4\% ou 8\% (SERAVALLI et al., 2016; FENG et al., 2015; LIU et al., 2015; CHUNG et al., 2013). Estes são estudos que visam entender a relação da sobrecarga salina como mecanismo causal da hipertensão arterial e suas consequências cardiovasculares. Contudo, no presente trabalho, o foco está em compreender mecanismos envolvidos em momentos que precedem a hipertensão arterial mensurável.

A ideia de que devemos compreender as etapas que antecedem a elevação da pressão arterial é fundamental na compreensão da patologia e potenciais alvos terapêuticos na prevenção da hipertensão arterial ou minimização de seus efeitos. Quais seriam os mecanismos de controle e de adaptação de um indivíduo que ingere alto teor de sal, porém não tem hipertensão arterial? De que forma nosso sistema fisiológico se adapta frente a esta influência externa cada vez mais presente na sociedade? Estes são questionamentos relevantes para este estudo. Por isso, a escolha dasobrecarga salina em $1 \%$ na água, pois se aproxima ao conteúdo de sódio ingerido por humanos. Alguns trabalhos, incluindo de nosso grupo, têm demonstrado que a sobrecarga salina em $1 \%$ não eleva os níveis de pressão arterial, mas são suficientes para desencadear alterações, principalmente vasculares (LACCHINI et al.,2011; SILVA, 2013; LIMA et al., 2013; SERAVALLI et al., 2016; GRAY et al., 2015). 
Valores elevados de sal (4 e 8\%), como são utilizados em algumas pesquisas, tornam a água de beber tão impalatável que os animais acabam por não ingerir líquidos, inviabilizando os resultados. A solução é então acrescentar tal teor de sal à ração. Contudo, alguns estudos já têm demonstrado consequências além das esperadas (hipertensão), onde o animal acaba por desenvolver lesões na mucosa oral e câncer gástrico (D'ELIA et al.,2014; GE et al., 2012). A seguir, serão apresentados resultados caracterizando o modelo experimental e mostrando que os animais, quando tratados com solução salina 1\% para beber, não sofrem alterações físicas importantes, como perda ou ganho de peso corporal e nem interrompem alimentação ou ingestão de água.

- Peso Corporal

Como esperado, apesar do aumentado teor de sal a que os animais foram expostos, não houve interferência no crescimento dos mesmos. Como se pode observar na Figura 7, os grupos tratados cresceram e ganharam peso tanto quanto 0 grupo controle, sendo este um indicativo de que a sobrecarga salina não trouxe estresse aos animais. Dados semelhantes foram encontrados em trabalhos anteriores realizados por nosso grupo, onde não encontramos alterações significantes em peso corporal após 6 semanas, nem após 12 e 18 meses de sobrecarga salina (LACCHINI ET AL, 2001; LACCHINI, 2001; LACCHINI, 2002).

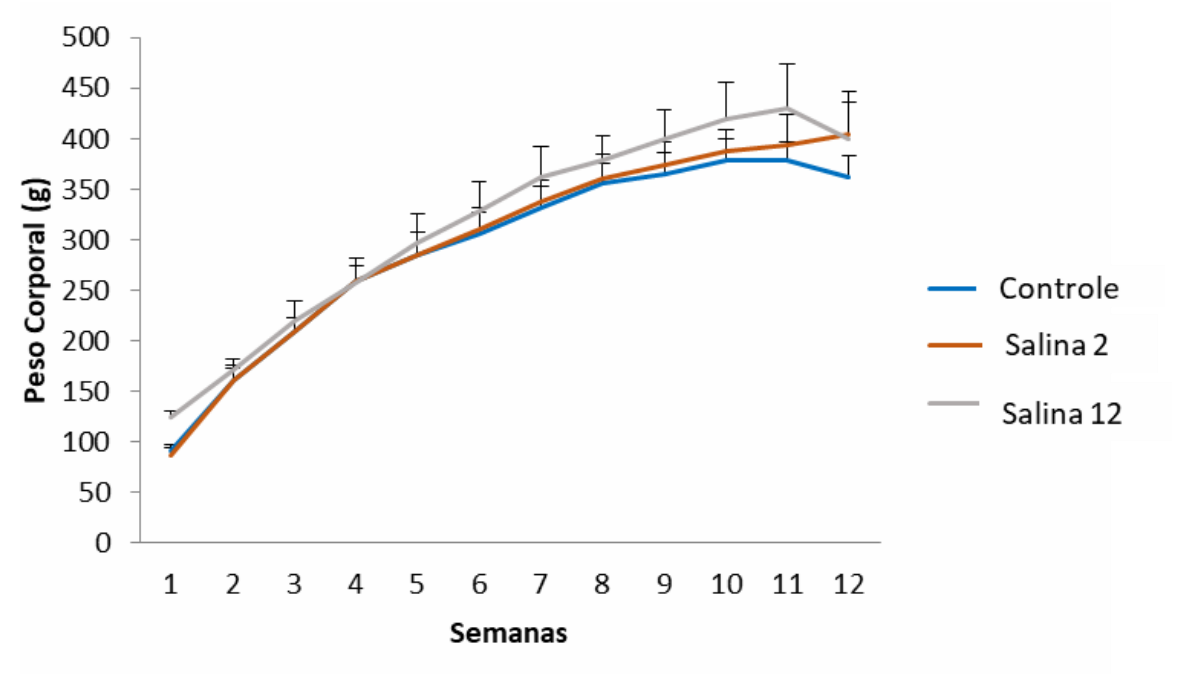

Figura 7: Curva temporal do ganho de massa corpórea (g), mostrando que a sobrecarga salina não interfere no ganho de peso corporal, nem de forma mais aguda (Sal-2) ou crônica (Sal-12). 
A avaliação do balanço hídrico envolveu a mensuração de 24 horas de ingestão de água e a excreção de urina. Como pode ser visto na Figura 8, a sobrecarga salina leva a um grande aumento da ingestão de água e de produção de urina. Já após 2 semanas de tratamento, ocorre aumento na ingestão de água $(+89,7 \%)$ e na produção de urina $(+104,2 \%)$. Além disso, a sobrecarga salina por período mais crônico (12 semanas) leva também ao aumento na ingestão de água $(+123,5 \%)$ e na produção de urina $(+146,8 \%)$. Embora os valores do grupos Sal-12 sejam maiores que no grupo Sal-2, estas diferenças não chegam a ser estatisticamente significantes.

Estes dados também corroboram com a literatura, uma vez que já se conhece a influência do alto teor de sal sobre o volume de fluido extracelular e a tonicidade corporal, com a ativação de diversos mecanismos regulatórios que levam à regulação da sede (STANHEWICZ e KENNEY, 2015; FORECH, et al.,2015). Além disso, também já foi mostrado que a ingestão elevada de sal aumenta os mecanismos diuréticos e natriuréticos (SILVA, 2013), via ativação do receptor de endotelina (JIN et al., 2016).
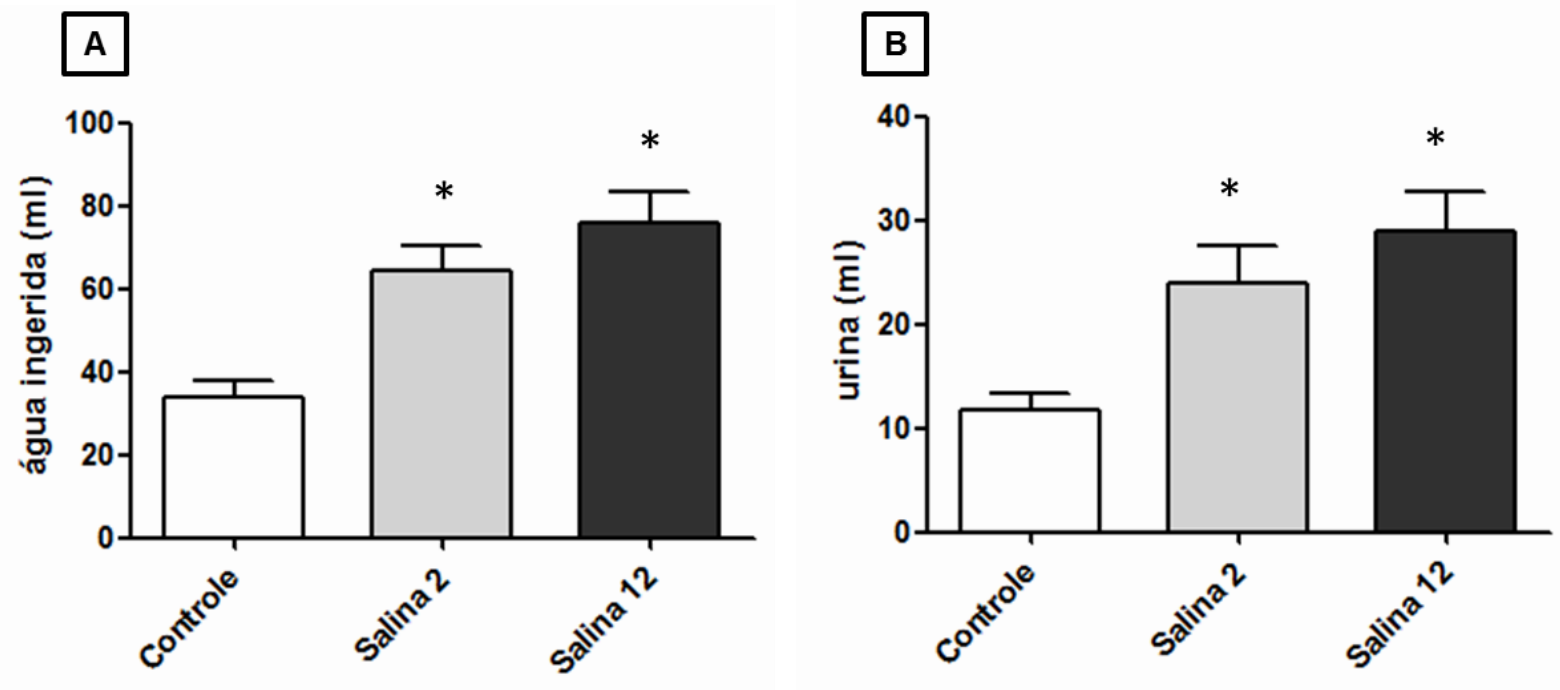

Figura 8: A: Valores médios de consumo hídrico $(\mathrm{ml})$. B: valores médios do volume urinário $(\mathrm{ml})$. Os grupos tratados com sobrecarga salina, tanto após 2 ou 12 semanas, apresentaram aumento significante da ingestão de água e da excreção de urina, se comparados ao grupo controle. ${ }^{*} p \leq 0,05$, comparado ao grupo Controle. 
- Balanço alimentar

A Figura 9 apresenta a avaliação do balanço alimentar, onde se verifica que a sobrecarga salina levou ao aumento do consumo de ração após 2 e 12 semanas de tratamento $(+27,1$ e $+33,3 \%$, respectivamente). Por outro lado, não houve diferença significante da excreção de fezes entre os grupos, sugerindo que os animais tratados com sobrecarga salina possam estar apresentando aumento de apetite, sem consequente aumento na produção de fezes, nos tempos avaliados.

Apesar dos animais não terem apresentado aumento significante de massa corporal, já apresentam um aumento na ingestão calórica. Alguns estudos têm proposto que a dieta da sociedade atual (rica em teor de sal e açúcar) pode colaborar com o quadro de obesidade visto atualmente. Alguns estudos, porém, já vêm observando que não somente isto é verdade, como também, indivíduos com sobrepeso ou obesidade apresentam maior consumo de sal, independente de estar ou não associado à ingestão açúcares (MCGREGOR, 2016; MOOSAVIAN et al., 2016).
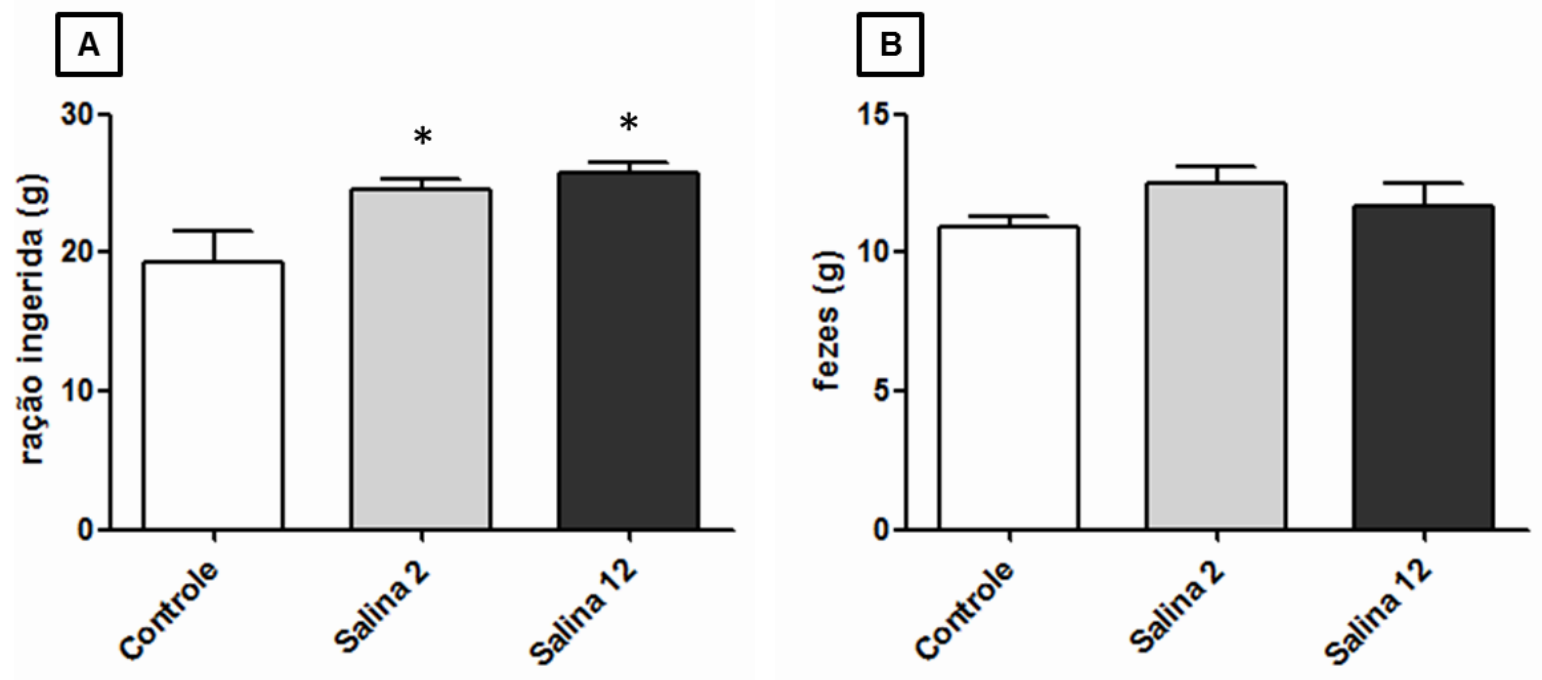

Figura 9: A: Valores médios de consumo de ração (g); B: valores médios de excreção de fezes $(\mathrm{g})$. Ambos os grupos tratados com sobrecarga salina apresentaram aumento na ingestão de ração se comparados ao grupo Controle. * $p \leq 0,05$, comparado ao grupo Controle. 
- Peso dos órgãos

Apesar do longo tratamento com sobrecarga salina, não observamos alterações significantes de pesos nos órgãos associados ao sistema cardiovascular (Tabela 5). Esta ausência de alterações era esperada, uma vez que os grupos não apresentaram alteração no ganho de peso corporal. Neste mesmo sentido, o aumento do peso relativo de órgãos relacionados ao sistema cardiovascular (coração, pulmões e rins) também não era esperado, visto que os grupos não apresentaram elevação de pressão arterial importante, como será mostrado a seguir.

Como complemento deste estudo, também foram pesados outros tecidos cuja função se relaciona ao metabolismo (glândulas adrenais, fígado e pâncreas). A Tabela completa apresentando os valores de peso de todos os tecidos coletados está apresentada no Anexo I.

Taleba 5 - Análise do peso relativo de coração, pulmões e rins de cada grupo experimental

\begin{tabular}{|c|c|c|c|}
\hline Órgãos & Controle & Sal-2 & Sal-12 \\
\hline Coração (g/cm) & $0,063 \pm 0,003$ & $0,065 \pm 0,004$ & $0,067 \pm 0,005$ \\
\hline Pulmões (g/cm) & $0,103 \pm 0,021$ & $0,110 \pm 0,026$ & $0,107 \pm 0,016$ \\
\hline Rins (g/cm) & $0,168 \pm 0,009$ & $0,167 \pm 0,010$ & $0,162 \pm 0,036$ \\
\hline
\end{tabular}

Peso normalizado pelo comprimento naso-anal $(\mathrm{g} / \mathrm{cm})$ 


\subsection{Estudo da Sobrecarga Salina no Controle Hemodinâmico}

5.2.1 Avaliação da Pressão arterial média (PAM), distólica (PAD) e sistólica (PAS)

Como esperado, a sobrecarga salina $1 \%$ não induziu aumento da pressão arterial média (Figura 10). Estes dados corroboram com outros trabalhos de nosso grupo, que mostram que esta quantidade de sal não induz a hipertensão arterial em ratos (LACCHINI et al., 2001), nem em camundongos tanto machos como fêmeas (LIMA et al., 2015; SILVA, 2013). Por outro lado, quando analisamos os valores médios de pressão arterial diastólica (PAD) e pressão arterial sistólica (PAS), observamos aumento significante nos valores de PAS (Figura 11B). Tal aumento nos leva a questionar e analisar mais profundamente os mecanismos de ajuste momento a momento da pressão arterial.

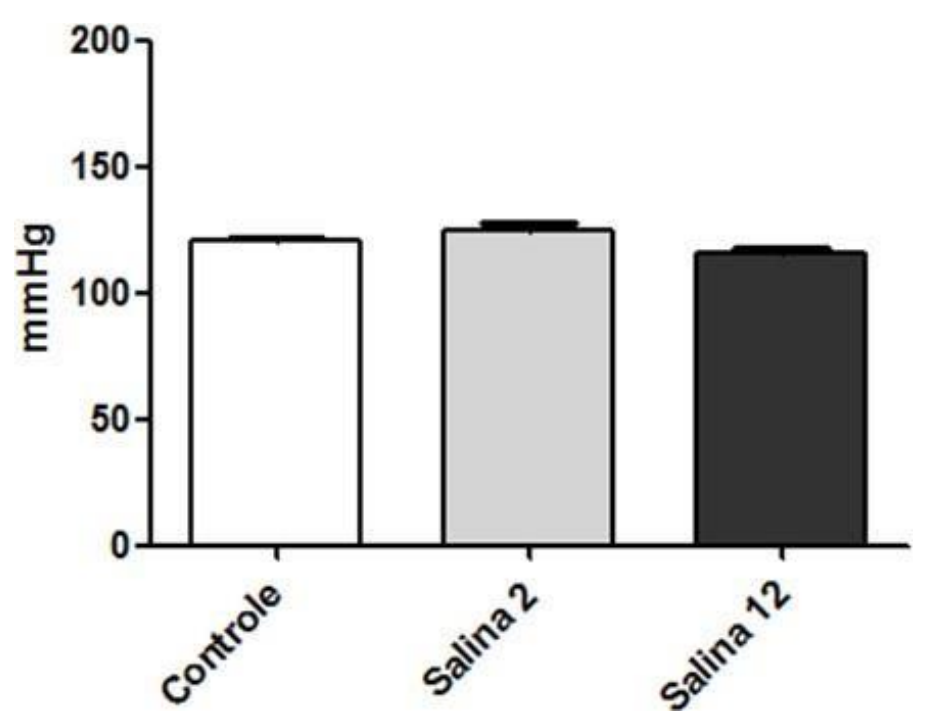

Figura 10: Média de valores de pressão arterial média $(\mathrm{mmHg})$ para cada grupo. Não observamos diferenças significantes entre os grupos estudados. 

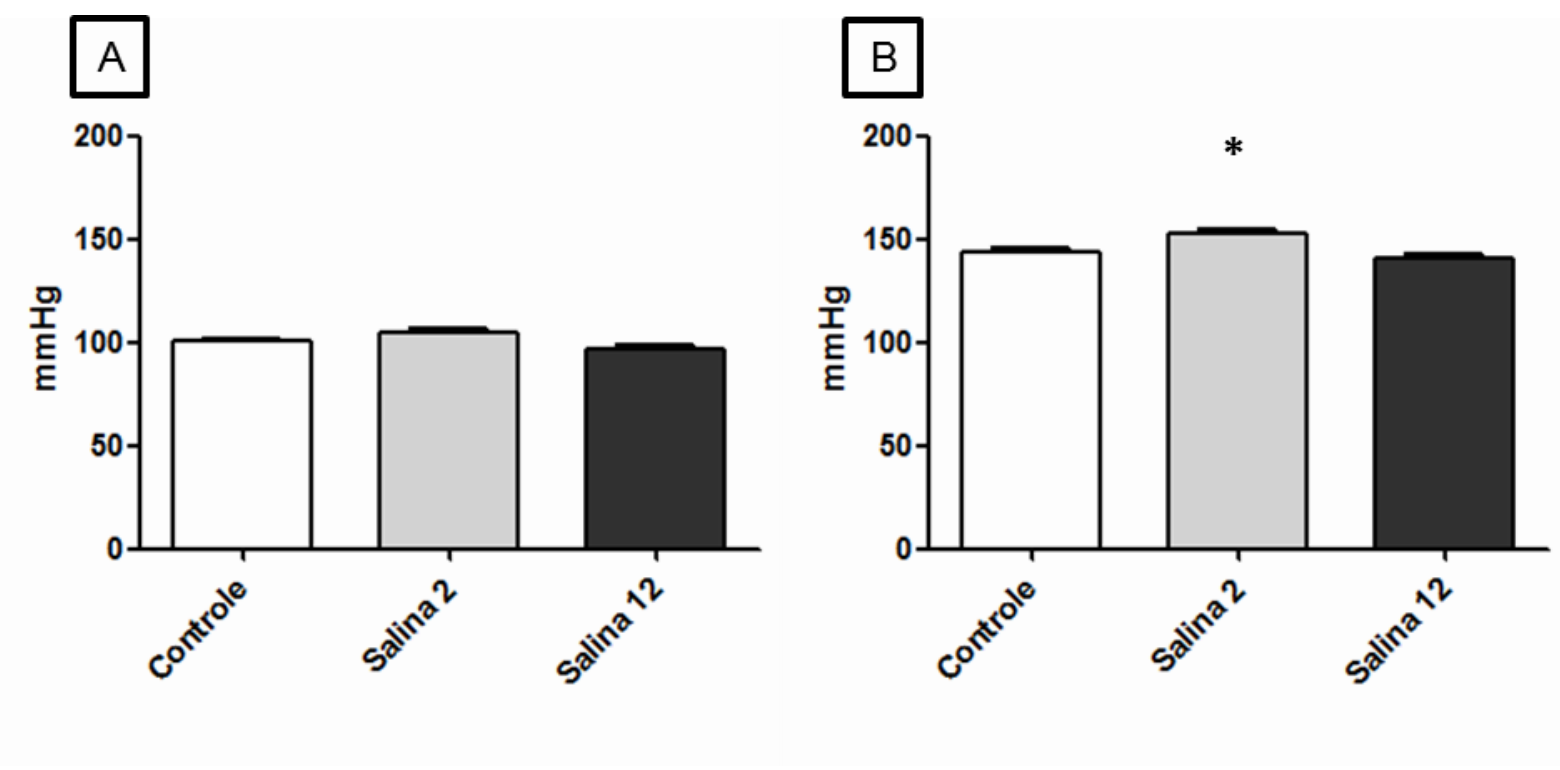

Figura 11: A: A média de valores de pressão arterial diastólica $(\mathrm{mmHg})$ não mostrou diferenças significantes entre os grupos estudados. B:Média dos valores de pressão arterial sistólica $(\mathrm{mmHg})$ para cada grupo, onde o tratamento com 2 semanas mostrou aumento significante em relação ao grupo controle. * $p \leq 0,05$, comparado ao grupo Controle.

\subsubsection{Estudo da pressão arterial sistólica e variabilidade da PAS}

Como já pudemos ver anteriormente, a sobrecarga salina levou ao aumento na PAS no grupo Sal-2, e que normaliza em Sal-12. Provavelmente, este aumento após 2 semanas representa um mecanismo de ajuste hemodinâmico precoce durante a adaptação ao aumento de volume imposto pela sobrecarga salina.

A variabilidade da pressão arterial representa oscilações desta ao longo do tempo. Como sabemos, é importante manter os valores de pressão arterial próximos para não alterar a perfusão tecidual e manter a integridade dos tecidos, a análise da variabilidade da pressão arterial nos dá a ideia de quanto esta oscila. Uma das formas de estudo no domínio do tempo é a análise da média dos desvios padrão. Seguindo esta ideia, a Figura 12B mostra que a variabilidade da PAS está significantemente 
aumentada no grupo Sal-12. Esta informação é muito importante na compreensão da modulação da pressão arterial (PA), visto que grandes oscilações de PA são acompanhadas por uma incapacidade do sistema em fazer sua supressão. Esta supressão é feita através das oscilações da frequência cardíaca (FC), mediadas pelos baroreceptores.

Por exemplo, aumentos de PA estimulam os barorreceptores, que levam a uma redução da FC, com consequente normalização da PA. Desta forma, a manutenção da variabilidade da PA em valores baixos tem importante relação com uma variabilidade alta da FC em indivíduos sem patologias cardiovasculares. Estes dados são tão importantes, que hoje se sabe que redução da variabilidade da FC e o aumento da variabilidade PAS são fatores de risco cardiovascular (JAMALI et al., 2016). Na Figura 13 será possível ver como a sobrecarga salina modifica a variabilidade da FC.
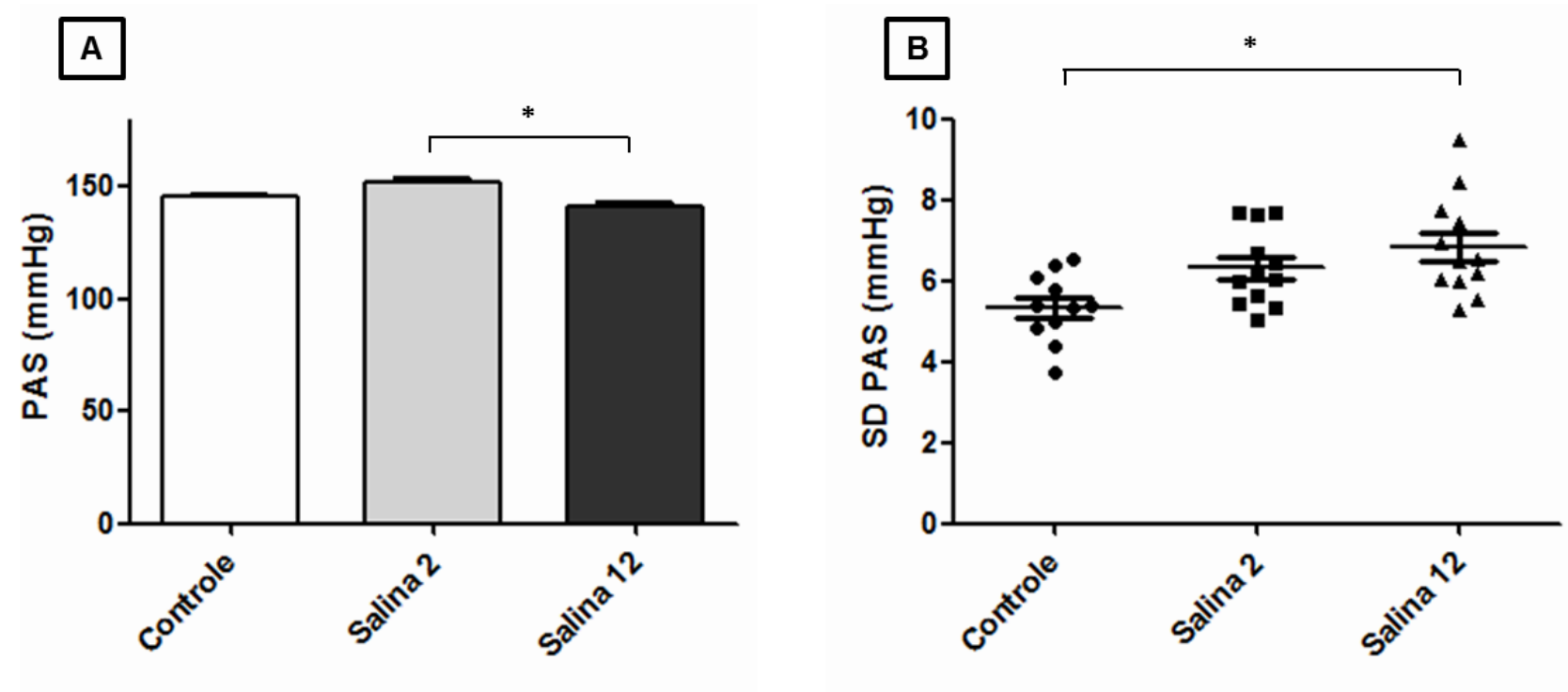

Figura 12 A: valores médios de PAS (mmHg) para cada grupo. Grupo Sal-2 estatisticamente significante em relação ao grupo Sal-12. B: desvio padrão para as médias de valores de PAS ( $\mathrm{mmHg}$ ) de cada grupo. Grupo Sal-12 estatisticamente significante em relação ao grupo controle. 


\section{- $\quad$ Avaliação da frequência cardíaca}

\subsubsection{Estudo da frequência cardíaca e intervalo $R R$}

A análise da frequência cardíaca mostrou que, apesar dos animais tratados não apresentarem um quadro de hipertensão, a FC aparece aumentada no grupo Sal-12, tanto comparado a Controle como Sal-2 (Figura 13). O estudo do intervalo de pulso RR corrobora com os dados de FC, mostrando redução no grupo Sal-12, embora o resultado não chegue a ser significante.

Resultados semelhantes já foram vistos em prole de ratos, em que o alto teor de sal na alimentação da mãe durante a prenhez, pode afetar diretamente os parâmetros cardiovasculares dos filhotes durante a fase adulta. Nestes, há aumento de FC, bem como alterações de pressão arterial (MOREIRA et al,.2014).
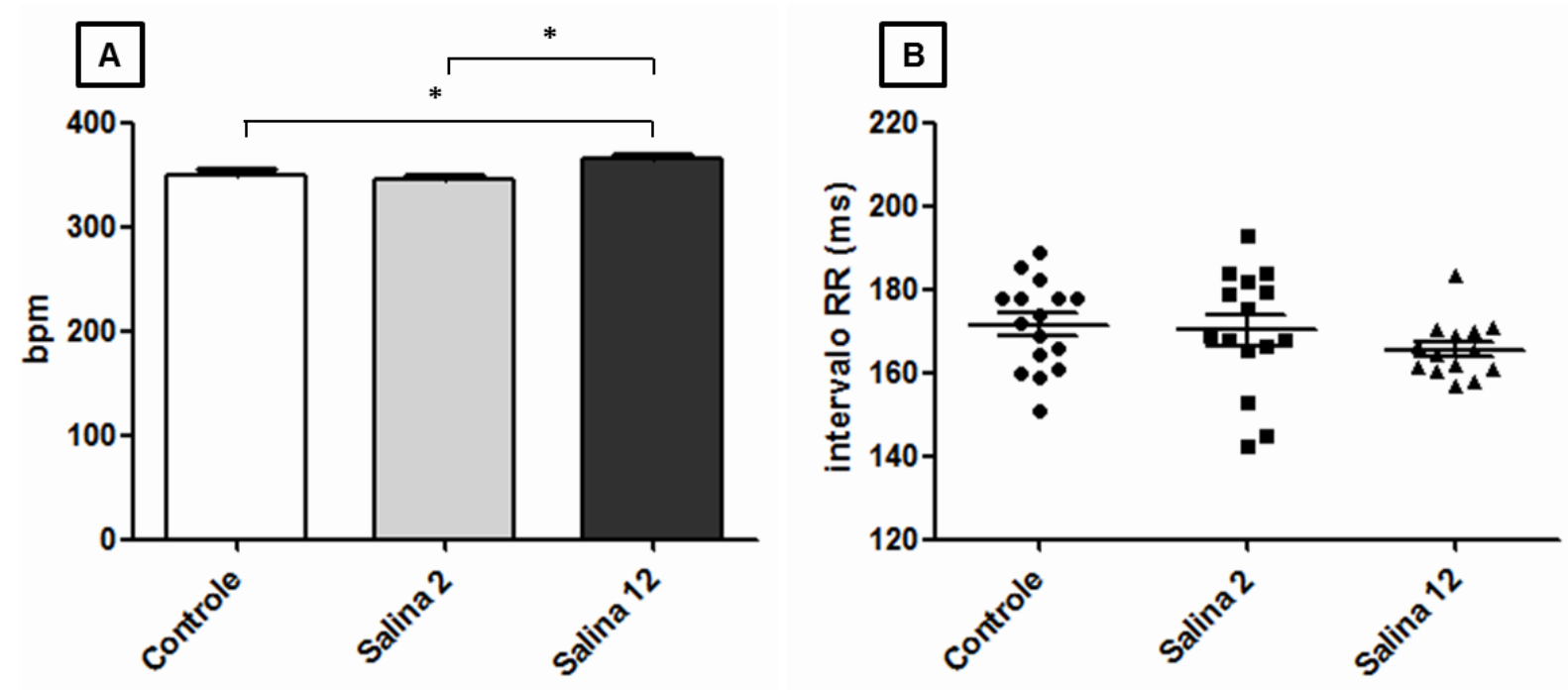

Figura 13: Avaliação da media dos valores de frequência cardíaca em bpm $(A)$ e do intervalo de pulso RR em milissegundos (B). Verificou-se aumento significante da frequência cardíaca $(A)$ nos ratos tratados com sobrecarga salina por 12 semanas quando comparados aos demais grupos. ${ }^{*} p \leq 0,05$, comparado ao grupo Controle. 


\subsubsection{Variabilidade da Frequência Cardíaca no Domínio do Tempo}

Quando avaliamos a variabilidade dos intervalos RR pelo desvio padrão, verificamos redução crescente com o aumento do tempo de sobrecarga salina (Figura 14A). A mesma redução é observada ao avaliar o desvio padrão do intervalo RR (Figura 14B) Esta redução na variabilidade do intervalo $R R$ é reconhecida atualmente como um fator de risco independente para eventos cardiovasculares (THAYER et al., 2010). Como comentado anteriormente, a redução da variabilidade da FC está relacionada a uma incapacidade de ajustes dos valores da PA, elevando sua variabilidade. Portanto, mesmo apresentando valores de PA compatíveis com a normotensão, os grupos que receberam sobrecarga salina mostram alterações nos mecanismos de controle cardiovascular que os aproximam do que se vê na hipertensão (STEVENS, et al, 2016; IRIGOYEN et al., 2016).
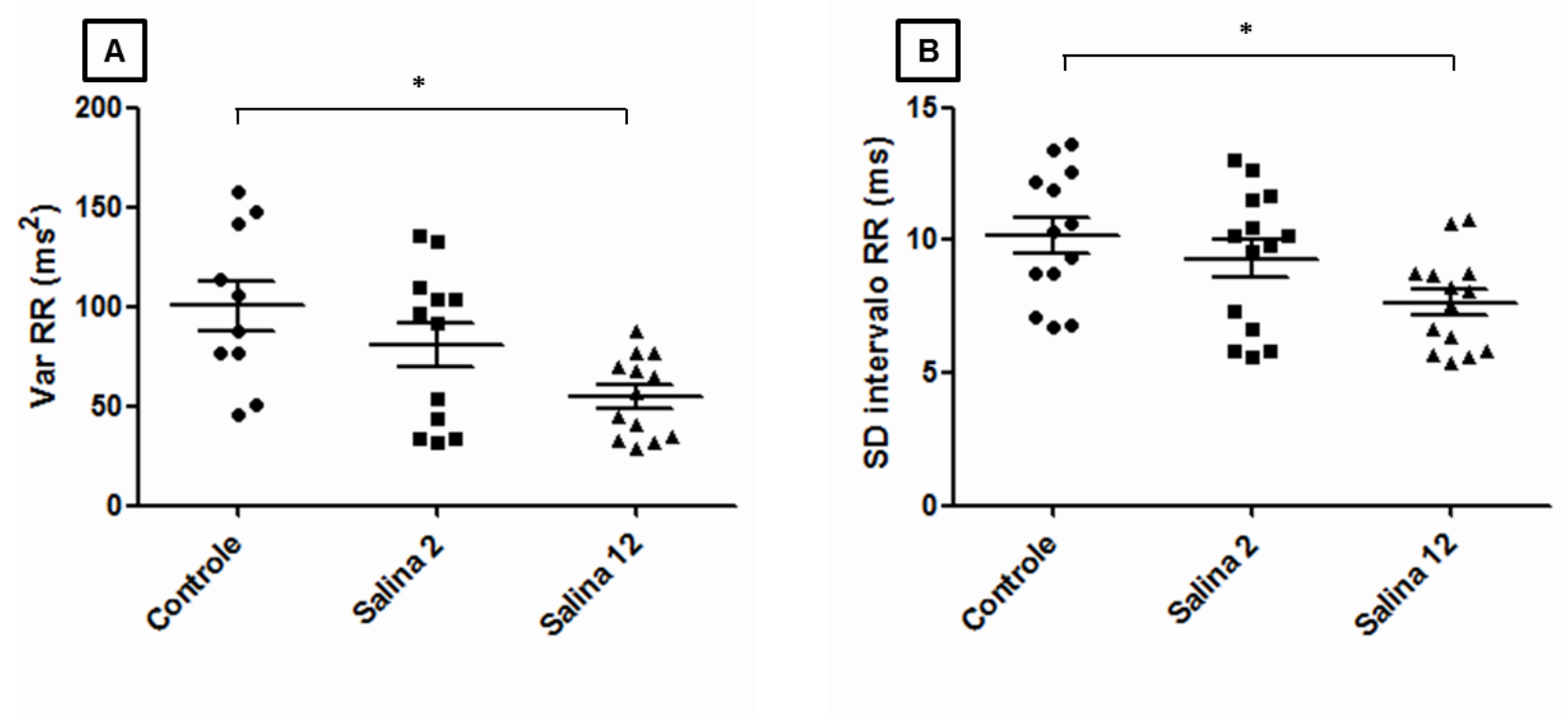

Figura 14: Avaliação da variabilidade da frequência cardíaca medida pela variabilidade do internalo $R R(A)$ e pela média dos valores de desvio padrão do intervalo $R R(B)$. Verifica-se redução significativa em ambas as variáveis para o grupo que recebeu sobrecarga salina por 12 semanas. ${ }^{*} p \leq 0,05$, comparado ao grupo Controle. 
Por outro lado, o RMSSD (Root Mean Square of the Successive Differences: raiz quadrada da média do quadrado das diferenças entre intervalos $R R$ consecutivos) não se alterou (Figura 15). Este índice está relacionado à ativação vagal, e fornece uma quantificação das variações abruptas da variabilidade, o que aparentemente não ocorreu entre os grupos. Talvez o aumento no tempo de sobrecarga salina venha a exacerbar possíveis alterações na modulação autonômica da PA e da FC. Um outro ponto que pode ser considerado é que, apesar das alterações de variabilidade da FC e da PA, este índice não mostra uma possível ativação vagal, considerada cardioprotetora.

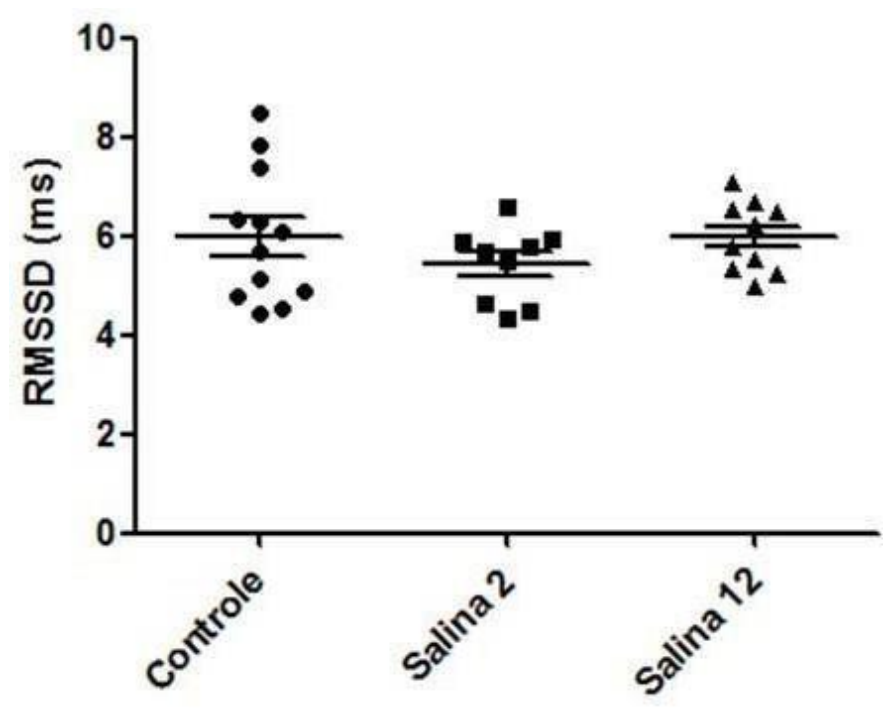

Figura 15: Valores médios de RMSSD para os grupos estudados. Não observados alterações importantes entre os grupos estudados.

Os resultados vistos até o momento mostram que a sobrecarga salina não somente leva à hiperatividade simpática, como também à diminuição da atividade parassimpática (Sal-2 e Sal-12, quando avaliada em valores percentuais). Tais características sugerem um quadro de disfunção autonômica. Já foi vista a existência desta disfunção em indivíduos pré-hipertensos que possuem dieta rica em sal (hiperatividade simpática e retirada vagal), sendo esta mais pronunciada do que nos normotensos que possuem dieta rica em sal (PAL et al.,2013). 


\subsubsection{Modulação Simpática e Parassimpática e VLF absoluta no domínio da frequência}

Quando avaliamos a modulação cardíaca em valores absolutos, observamos aumento da atividade simpática (LF) no grupo Sal-12 em relação ao grupo controle (Figura 16). O mesmo não ocorre com a modulação parassimpática e nem com valores de VLF, que se mostram constantes entre os grupos (Figura 17). Estes resultados vão ao encontro da observação do aumento de variabilidade da PA e redução da variabilidade da FC, visto que estes são mais relacionados ao aumento da atividade simpática. A ausência no aumento da atividade parassimpática corrobora a ausência de ativação vagal (calculada pelo RMSSD, Figura 15).

É importante lembrar que:

VLF - Very Low Frequency: potência contida na faixa abaixo de $0,04 \mathrm{~Hz}$ (Não se sabe ao certo quais os mecanismos envolvidos, alguns pesquisadores sugerem a modulação proveniente do SRAA)

LF - Low Frequency: potência contida na faixa de 0,04 a $0,15 \mathrm{~Hz}$ (Indicativo de atividade simpática).

HF - High Frequency: potência contida na faixa de 0,15 a $0,4 \mathrm{~Hz}$ (Indicativo de atividade parassimpática) 

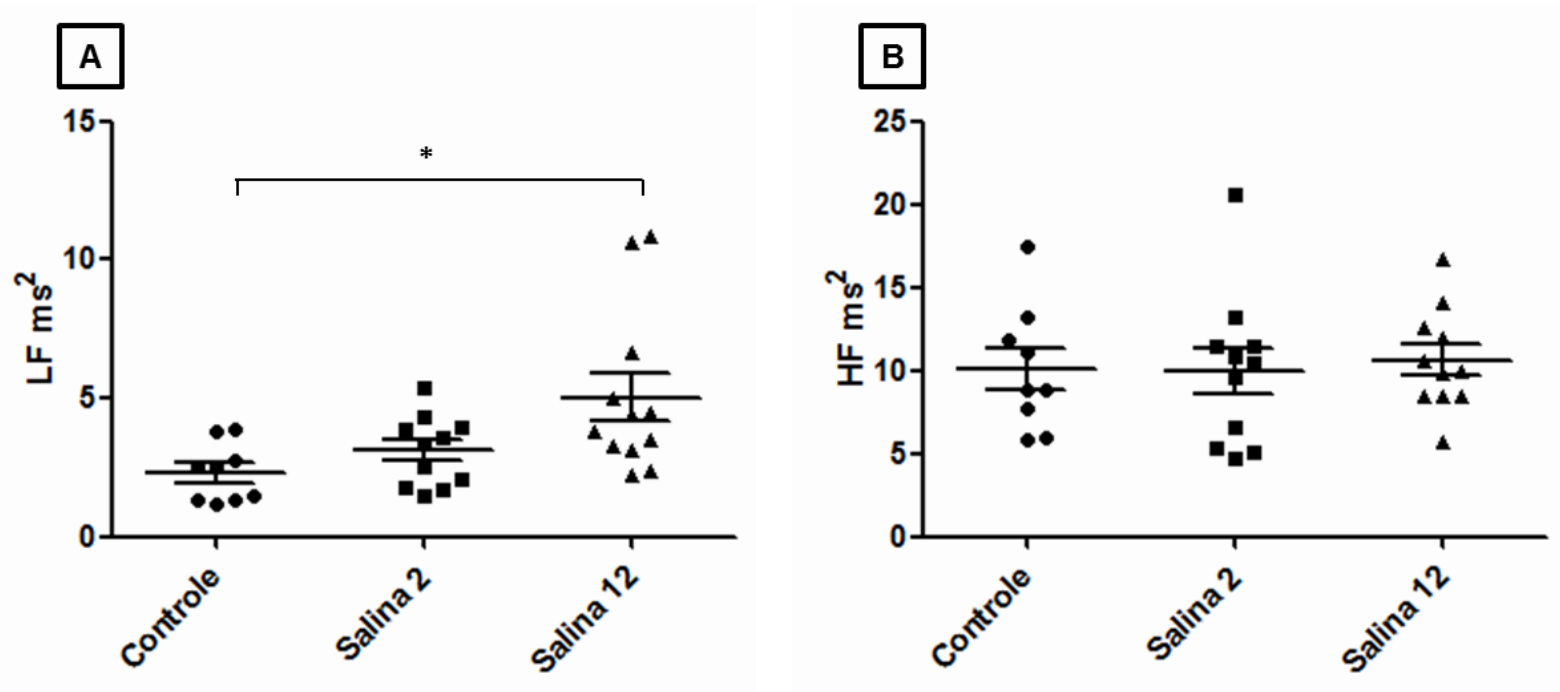

Figura 16: A: índices de modulação simpática (LF) no domínio do tempo, onde se observa aumento significante no grupo tratado por 12 semanas. B: índices de modulação parassimpática (HF) no domínio do tempo, onde não foram encontradas diferenças significantes. ${ }^{*} p \leq 0,05$, comparado ao grupo Controle.

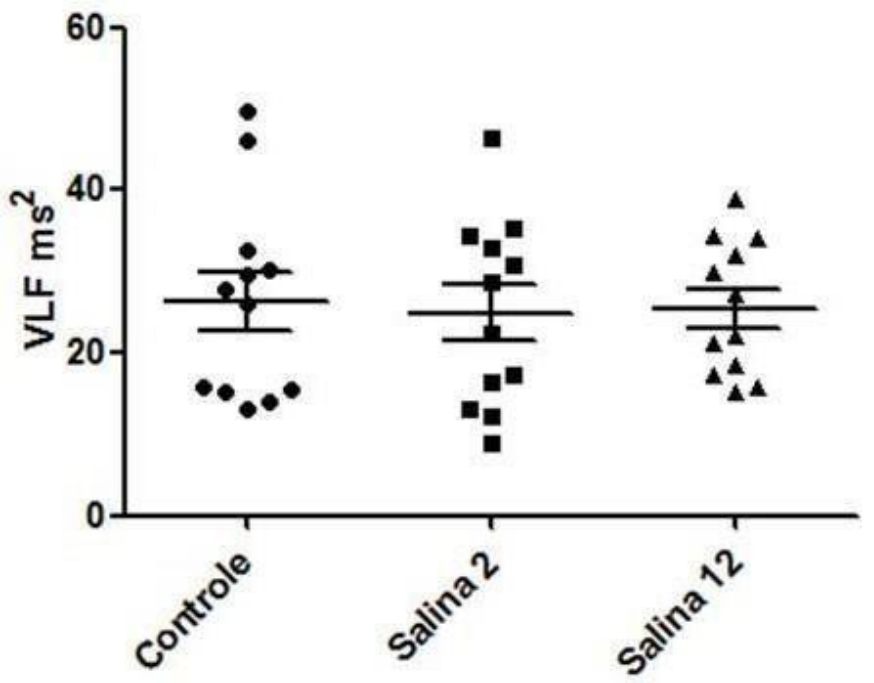

Figura 17: Índice de modulação VLF (outros mecanismos regulatórios como SRAA) no domínio do tempo. Não foram encontradas diferenças significantes entre os grupos estudados. 
Ao avaliar a porcentagem das potências de sinal (\%LF e \%HF), verifica-se que o grupo Sal-2 aumenta \%LF e reduz \%HF comparado ao controle e que o grupo sal-12 apresenta aumento ainda maior de \%LF e redução ainda maior de \%HF (Figura 18). Isso significa que há progressivamente aumento da participação simpática e redução da participação parassimpática sobre a modulação cardíaca nos animais que recebem sobrecarga salina. Estes resultados corroboram o que foi observado em estudo conduzido em indivíduos normotensos sensíveis ao sal. Neste estudo, durante a ingestão de alto teor de sal, os indivíduos apresentaram modulação cardíaca vagal reduzida, bem como uma redução da inibição simpática vascular (CASTIGLIONI et al.,2016).
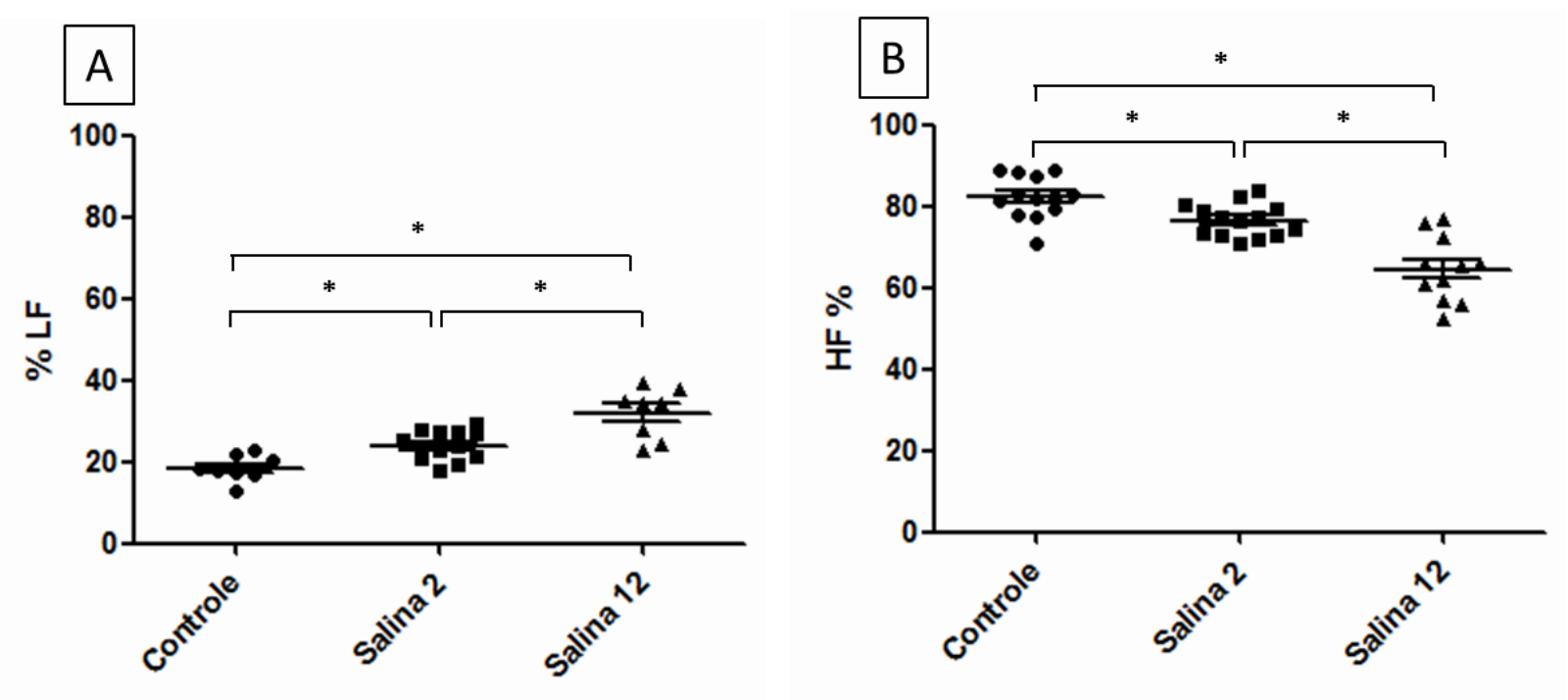

Figura 18: A: porcentagem da modulação simpática (LF\%) mostrando aumento progressivo nos grupos Sal-2 e Sal-12 em relação so Controle. B: porcentagem da modulação parassimpática $(\mathrm{HF} \%)$ mostrando redução progressiva nos grupos Sal- 2 e Sal-12 em relação so Controle. * $p \leq 0,05$, comparado ao grupo Controle. 


\subsubsection{Balanço Simpato-Vagal}

O balanço simpato-vagal é obtido quando se avalia a razão entre LF e HF, indicando quanto de ação o parassimpático tem para modular o simpático. A razão LF/HF mostra participação proporcionalmente maior do simpático com o aumento do tempo de sobrecarga salina (Figura 19).

É importante notar que esta razão corrobora os resultados obtidos na avaliação da modulação simpática e parassimpática (Figuras 18 A e B). Considerando condições normais de modulação mediada pelo sistema nervoso autônomo sobre o coração, o desbalanço entre as ações do sistema nervoso simpático e parassimpático caracteriza um quadro de disfunção autonômica, observado em indivíduos hipertensos (SOROTA, 2014).

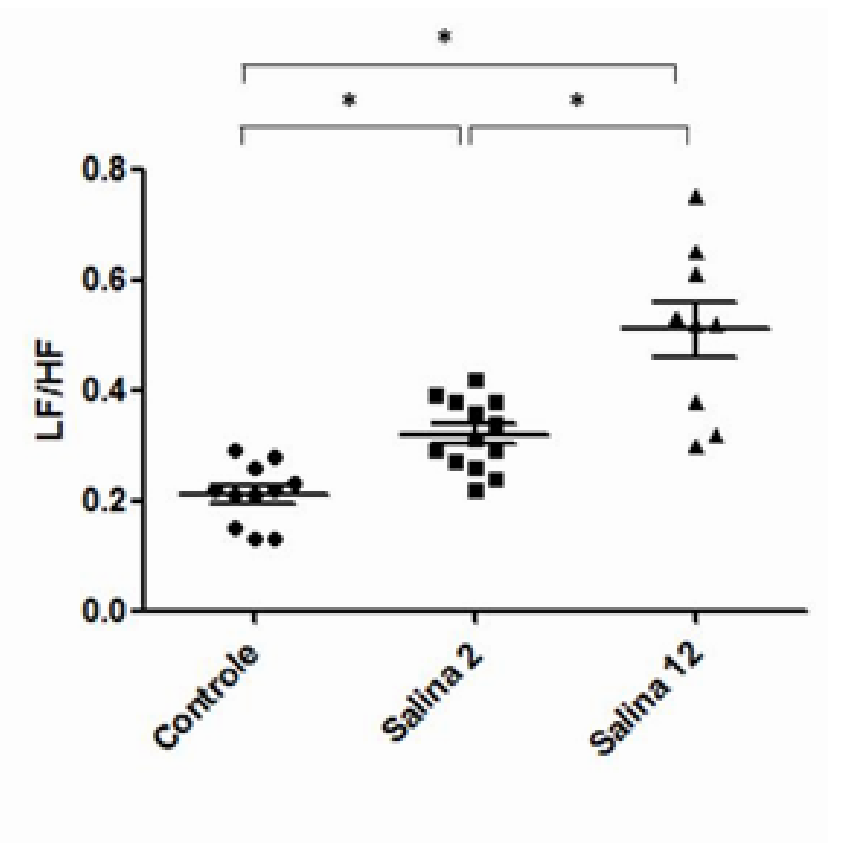

Figura 19: Balanço simpato-vagal, ou seja a proporção da influência do sistema simpático sobre a proporção da inflûência parasimpática cardíaca em resposta a sobrecarga salina entre os grupos. ${ }^{*} p \leq 0,05$, comparado ao grupo Controle. 


\subsubsection{Sensibilidade Barorreflexa Espontânea}

A sensibilidade barorreflexa espontânea pode ser avaliada pela pelas oscilações espontâneas entre pressão arterial e frequência cardíaca. Desta forma, semelhante ao que observamos nas avalições barorreflexas usando substâncias vasoativas (que promovem vasoconstrição ou vasodilatação), a indução de alterações na PA estimulam os barorreceptores a modificar a FC, trazendo os valores de PA de volta à normalidade. Assim, o indice Alfa permite estudar como os barorreceptores atuam sobre as oscilações naturais da PA. Na Figura 20A, é apresentado o índice ALFA (em bpm/mmHg), mostrando que aparentemente não há alteração espontânea desta sensibilidade.

Porém, ao avaliar especificamente a participação de HF (parassimpático) sobre esta sensibilidade dos pressorreceptores, verifica-se novamente redução tanto após 2 como 12 semanas de sobrecarga salina (Figura 20B), dado que corrobora com a diminuição na modulação da FC.
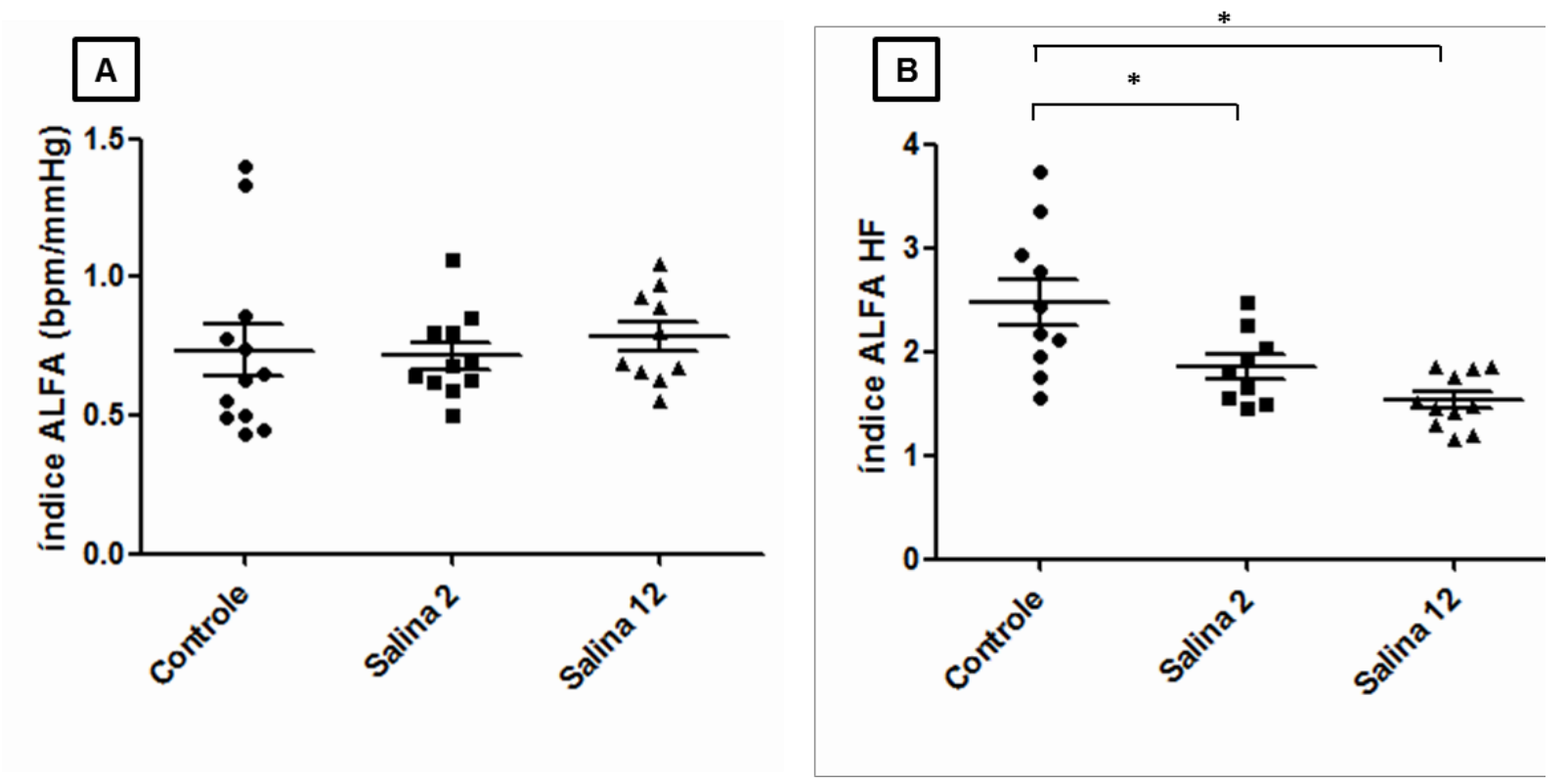

Figura 20: A: O índice Alfa mostra que, aparentemente, não há alteração na sensibilidade barorreflexa espontânea entre os grupos; B: A participação parassimpática na sensibilidade barorreflexa espontânea está reduzida nos grupos tratados com sobrecarga salina. ${ }^{*} p \leq 0,05$, comparado ao grupo Controle. 
Apesar dos resultados observados, a sensibilidade espontânea barorreflexa parece não estar prejudicada nos grupos com sobrecarga salina. Contudo, não é necessário verificar alteração em todas as variáveis associadas à modulação cardiovascular para considerarmos que existe uma disfunção autonômica. Neste sentido, já se observa uma participação parassimpática menor em tal reflexo autonômico. Podemos pensar que não houve uma desensibilização barorreflexa ainda, mas que talvez, em tempos maiores do que 12 semanas de tratamento ou sob associação de outra variável, possa se observar redução efetiva da sensibilidade barorreflexa.

Como não poderiam ser diferentes, as alterações encontradas sobre a modulação cardíaca (FC) refletiram sobre a modulação periférica (PAS). O aumento significante da PAS logo com 2 semanas de tratamento comprova este fato. $\mathrm{O}$ fato dos animais que receberam sobrecarga salina ainda não terem desenvolvido um quadro hipertensivo provavelmente se deve a adaptações morfológicas e funcionais que conseguem manter o nível de pressão arterial constante. Porém, nem todo mecanismo de adaptação acaba por ser benéfico.

Apesar da PAM, PAD e parcialmente da PAS se manterem em níveis normais, podemos observar aumento significante na variabilidade da PAS no mesmo momento em que ocorre a normalização da PAS (após 12 semanas de sobrecarga salina). Como mencionado anteriormente, a variabilidade da PA e da FC são marcadores independentes para risco cardiovascular (JAMALI et al., 2016; FLORAS et al., 1988). Desta forma, embora os grupos Sal-2 e Sal-12 se mantenham normotensos, a modulação autonômica mostra que estão muito próximos do desenvolvimento de um quadro hipertensivo, e a identificação do fator (ou fatores) que ainda mantém estes indivíduos normotensos pode ser fator determinante na prevenção e tratamento da hipertensão. 


\subsubsection{Análise de Débito Cardíaco e índice Cardíaco}

O débito cardíaco (DC) representa o volume de sangue bombeado pelo coração a cada minuto. As relações entre volume sistólico e frequência cardíaca não são tema específico do presente estudo, mas o entendimento do DC ajuda a compreender o desempenho do coração, também representado pelo índice cardíaco (IC). Quando avaliamos os valores de DC e IC nos grupos que receberam sobrecarga salina (tanto por 2 como 12 semanas), é possível verificar redução em relação aos Controles, embora não significante (Figura 21). Se pensarmos que os grupos tratados com sobrecarga salina não foram expostos a algum tipo de lesão cardíaca ou determinando importante alteração de pressão arterial, é de se esperar que não ocorram mudanças significantes no desempenho cardíaco.
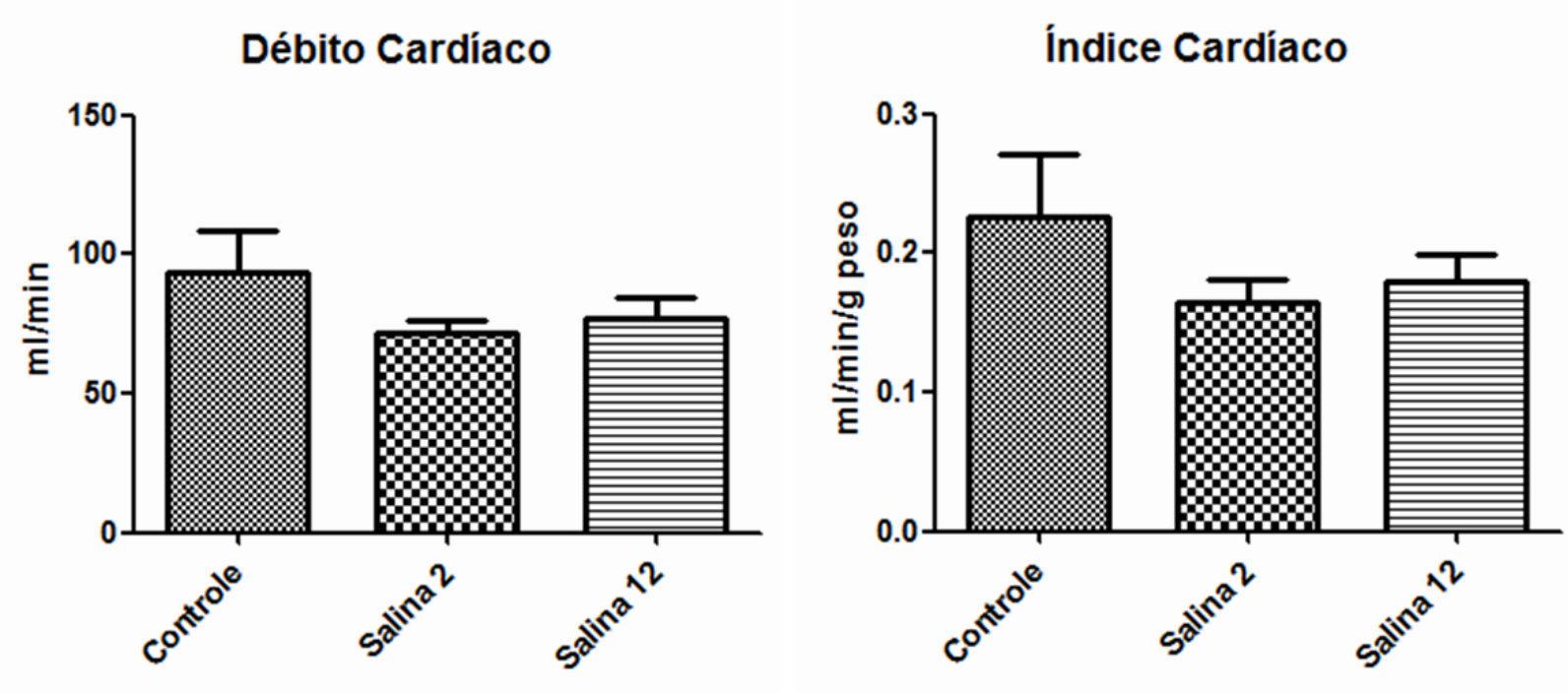

Figura 21: A: índice médio de débito cardíaco. B: índice médio do índice cardíaco. Os dois índices não mostram alteração importante no desempenho cardíaco nos grupos que receberam sobrecarga salina. 
Os resultados obtidos neste estudo do controle hemodinâmico trazem questionamentos importantes sobre os processos envolvidos com a adaptação cardiovascular à sobrecarga salina. O simples fato de não observarmos alteração importante de pressão arterial poderia ser determinante na visualização do modelo experimental como ineficaz na modulação de qualquer variável hemodinâmica. Contudo, o desenho experimental deste estudo permitiu mostrar que existem mecanismos autonômicos sendo alterados, possivelmente iniciando pelo controle sobre a atividade simpática e parassimpática, modificando a sensibilidade do reflexo barorreceptor e possivelmente levando, finalmente, à alteração da variabilidade da PA e da FC.

A Figura 22 resume estes mecanismos observados nos grupos Sal-2 e Sal-12, sugerindo que a alteração da variabilidade de PA e de FC sejam reflexo da modificação da atividade autonômica. O que não fica claro é como animais com alterações autonômicas e na variabilidade da PA e da FC, compatíveis com um estado hipertensivo, não culminem com a elevação efetiva da pressão arterial. Neste momento, pode-se questionar que mecanismos estão envolvidos na manutenção da PA em valores semelhantes aos de um indivíduo normotenso. A partir daí, torna-se importante entender o que ocorre com a estrutura e função vascular. Possivelmente, existe a produção de mediadores que ajudam a manter a resistência vascular ou que levam ao remodelamento vascular, de modo a equilibrar a pressão arterial sistêmica. Isso está de acordo com alterações em diferentes leitos vasculares que, somadas, podem auxiliar no controle pressórico. 


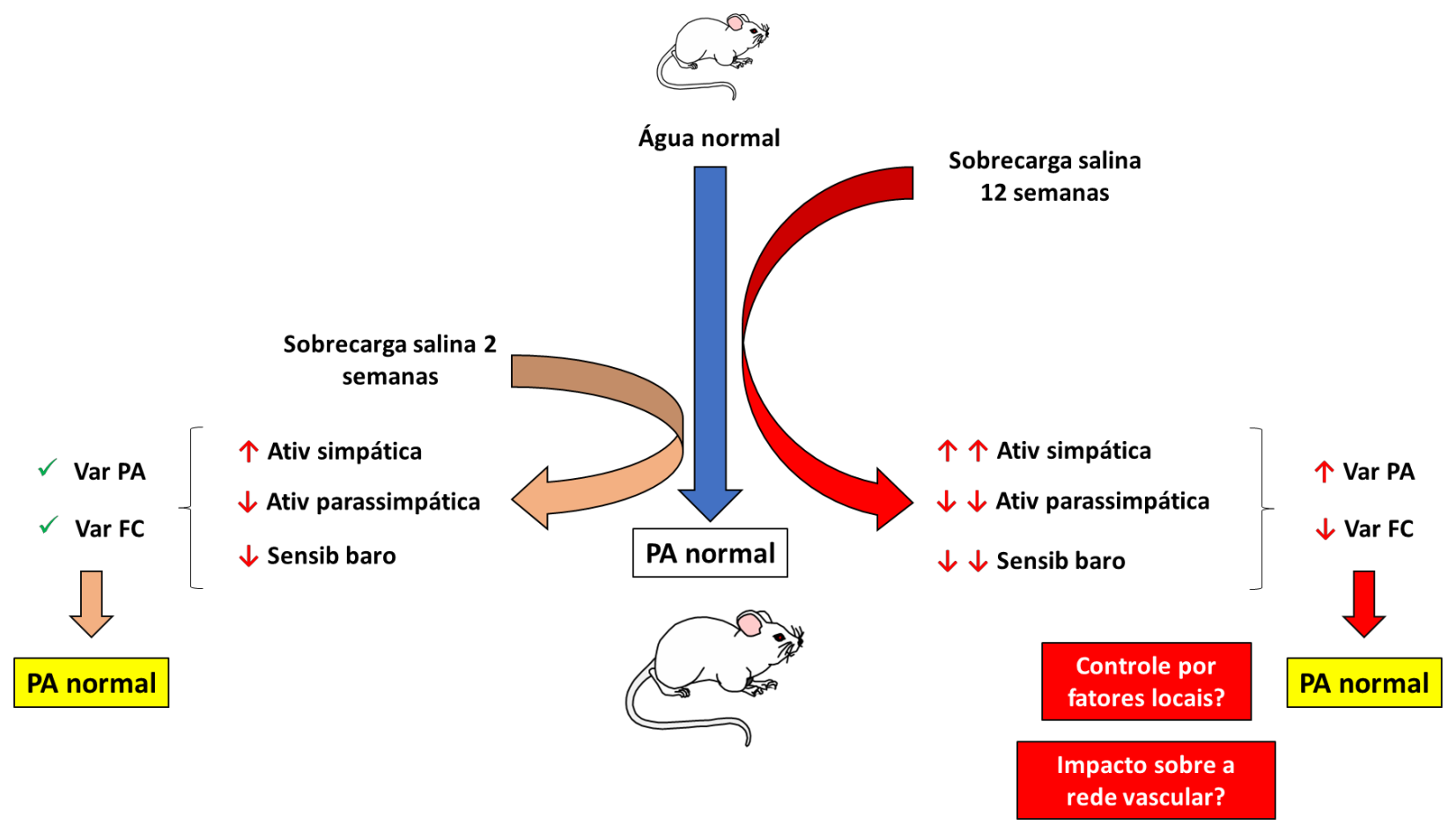

Figura 22: Resumo esquemático dos principais resultados obtidos no estudo hemodinâmico, diferenciando os efeitos observados nos animais que receberam sobrecarga salina por período mais curto e crônico. Var: variabilidade; PA: pressão arterial; FC: frequência cardíaca; Baro: barorreceptores.

Estes achados são compatíveis com uma condição semelhante ao estado de pré-hipertensão $(\mathrm{PH})$, que é atribuída a indivíduos que possuam de 120 a 139 $\mathrm{mmHg}$ de pressão arterial sistólica e 80 a $89 \mathrm{mmHg}$ de pressão arterial diastólica. Porém, muito mais do que uma "fase de transição entre saudável e doente", definida pelo uso de pontos de corte da pressão arterial, a $\mathrm{PH}$ pode se tornar mais relevante e diagnosticada pelas alterações hemodinâmicas.

Como podemos ver até o momento, a sobrecarga salina, ainda que em dose não hipertensora, já está induzindo a alterações hemodinâmicas, aumentando a atividade simpática cardíaca e atenuando a atividade parassimpática cardíaca. Tal ponto se torna relevante quando muitos trabalhos vêm mostrando a influência da atividade simpática sobre o SRAA, função renal e remodelamento vascular 
(SHIMOURA et al., 2017; PITRA et al., 2016). Desta forma, podemos considerar que a sobrecarga salina altera a modulação autonômica, reduzindo a variabilidade da FC, aumentando a variabilidade da PA. Assim, torna-se imprescindível identificar alterações estruturais e/ou funcionais sobre diferentes leitos vasculares. Neste caso, temos como principais alvos estudar uma artéria de grande calibre (artéria elástica) e uma artéria de pequeno calibre (artéria muscular). A partir daí, decidiu-se estudar, respectivamente, a aorta e a artéria mesentérica.

\subsection{Estudo do Fluxo Tecidual}

O estudo do fluxo tecidual pelo método das microesferas reflete o grau de remodelamento vascular e/ou do estado de contração/relaxamento das artérias responsáveis pela irrigação do tecido estudado. Ao avaliar o fluxo, este método permite o estudo de diversos tecidos, como pode ser visto no Anexo II. Porém, como o presente trabalho se restringiu à aorta e às artérias mesentéricas, iremos apresentar e discutir apenas estes dados.

Os resultados mostram aumento no fluxo sanguíneo na aorta dos grupos tratados com sobrecarga salina, especialmente o grupo Sal-12, embora não significante (Figura 23). Talvez este aumento se relacione ao remodelamento dos vasos responsáveis pela nutrição da parede aórtica. Estes vasos não são visíveis com facilidade em ratos, devido ao tamanho reduzido destes animais. Contudo, abrem perspectiva para um possível estudo que poderia aprofundar a análise ultraestrutural da parede aórtica.

Para estudar o fluxo das artérias mesentéricas pelo método das microesferas, avaliamos o fluxo no intestino delgado. Esta medida de fluxo sanguíneo no intestino, mostrou redução importante em ambos os grupos tratados com sobrecarga salina. Considerando-se que a perfusão do intestino é feita pelos ramos das artérias mesentéricas, a grande redução de fluxo tecidual deve estar diretamente relacionada com o remodelamento e/ou com um aumentado estado de contração destes vasos. $O$ remodelamento vascular nas artérias mesentéricas pode levar ao aumento ${ }_{5} \mathrm{qla}$ 
resistência vascular local e representar um dos mecanismos causadores da redução do fluxo sanguíneo.
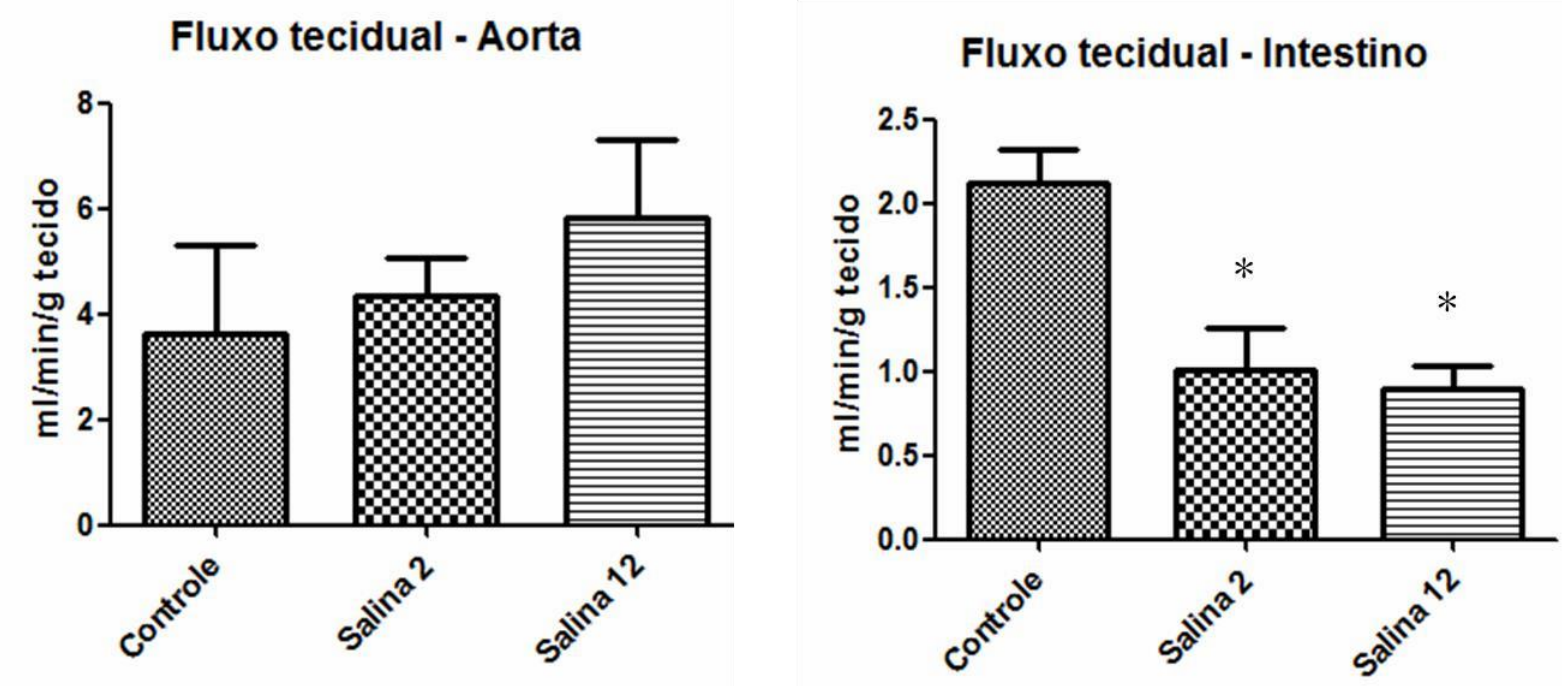

Figura 23: Fluxo tecidual de microesferas no intestino. Houve redução na perfusão tecidual nos grupos tratados com sobrecarga salina. * $p \leq 0,05$, comparado ao grupo Controle.

\subsection{Estudo biomecânico da Aorta}

A análise estrutural da aorta normalmente é feita avaliando a composição celular e acelular da sua parede usando métodos histológicos. Uma forma importante de entendermos como a composição da parede resulta em estados de rigidez ou de capacidade da parede suportar variações de pressão é o estudo biomecânico. $\mathrm{Na}$ Figura 24, vemos que a avaliação biomecânica da aorta torácica indica uma importante alteração da composição da parede aórtica (quantitativa e/ou qualitativa) no grupo que está se adaptando à sobrecarga salina (Sal-2), onde ocorre aumento da espessura da parede $(+30,7 \%)$, sem necessariamente aumentar sua resistência. Isto pode ser interpretado pela redução da força necessária para ruptura da aorta $(-22,9 \%)$ e estresse aplicado (-28,3\%), além de um aumento na deformação do vaso $(+35 \%)$.

Por outro lado, o grupo tratado por 12 semanas com sobrecarga salina parece ter se adaptado às mudanças estruturais momentâneas e possivelmente atingiu um ponto de equilíbrio, mantendo sua resistência semelhante àquela dos animais 
controle. Contudo, a redução do estresse de falência (embora não significante) é importante $(-26 \%)$ e pode sugerir que a adaptação da parede aórtica não foi completamente adequada, levando a um vaso mais frágil. Esta característica pode ser determinante para respostas mais crônicas ou concomitantes a outros estressores, levando a uma tentativa de ajuste de tensão a aumento na deposição de colágeno.
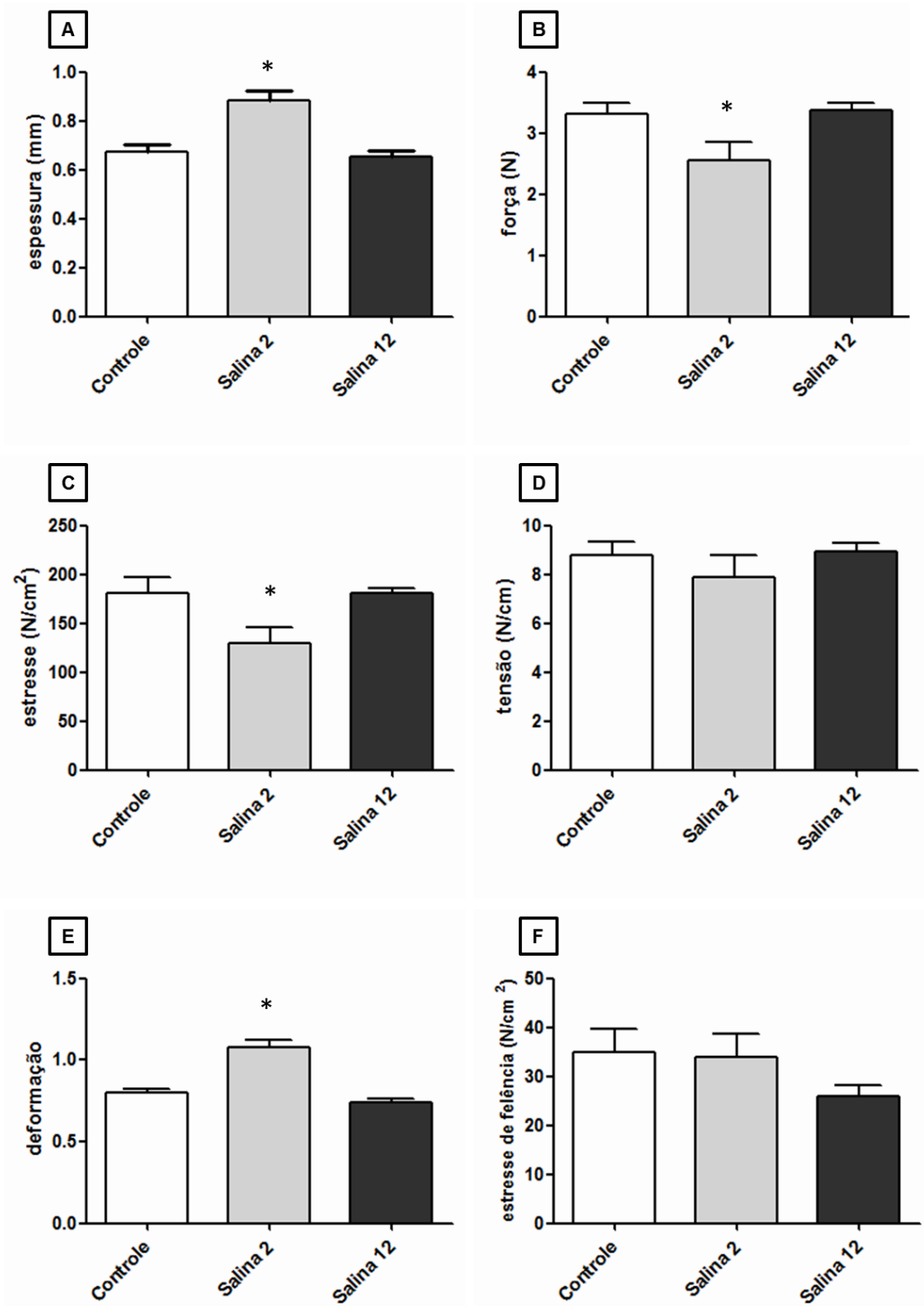

Figura 24: A: Espessura (mm) - média das espessuras da aorta em cada grupo; B: Força (N) utilizada para a ruptura da arteria; c: Estresse $(\mathrm{N} / \mathrm{cm} 2)$ : indicativo de rigidez arterial; D: Tensão (N/cm): tensão exercida sobre o vaso; E: Deformação $(\mathrm{cm})$ : indicativo de componente elástico arterial; $\mathrm{F}$ - Estresse de falência ( $\mathrm{N} / \mathrm{cm} 2)$ : força exercida até a ruptura da artéria. ${ }^{*} p \leq 0,05$, comparado ao grupo Controle. 
Considerando os resultados apresentados até o momento, pode-se entender que a sobrecarga salina impõe alterações autonômicas e de variabilidade de PA e de FC, mas que a pressão arterial sistêmica se mantém próxima de valores considerados normais. Mecanismos importantes que podem sofrer alteração com a sobrecarga salina são o fluxo sanguíneo e a rigidez da aorta. Neste sentido, verificamos que o fluxo de sangue pelas artérias mesentéricas está diminuído, sugerindo que estas tenham apresentado ou alteração no seu funcionamento ou modificação na sua estrutura. Por outro lado, a aorta apresentou alterações de rigidez e elasticidade em tempo menor de tratamento, enquanto mostrou redução da sua capacidade de suportar distensões quando a sobrecarga salina é crônica (Figura 25).

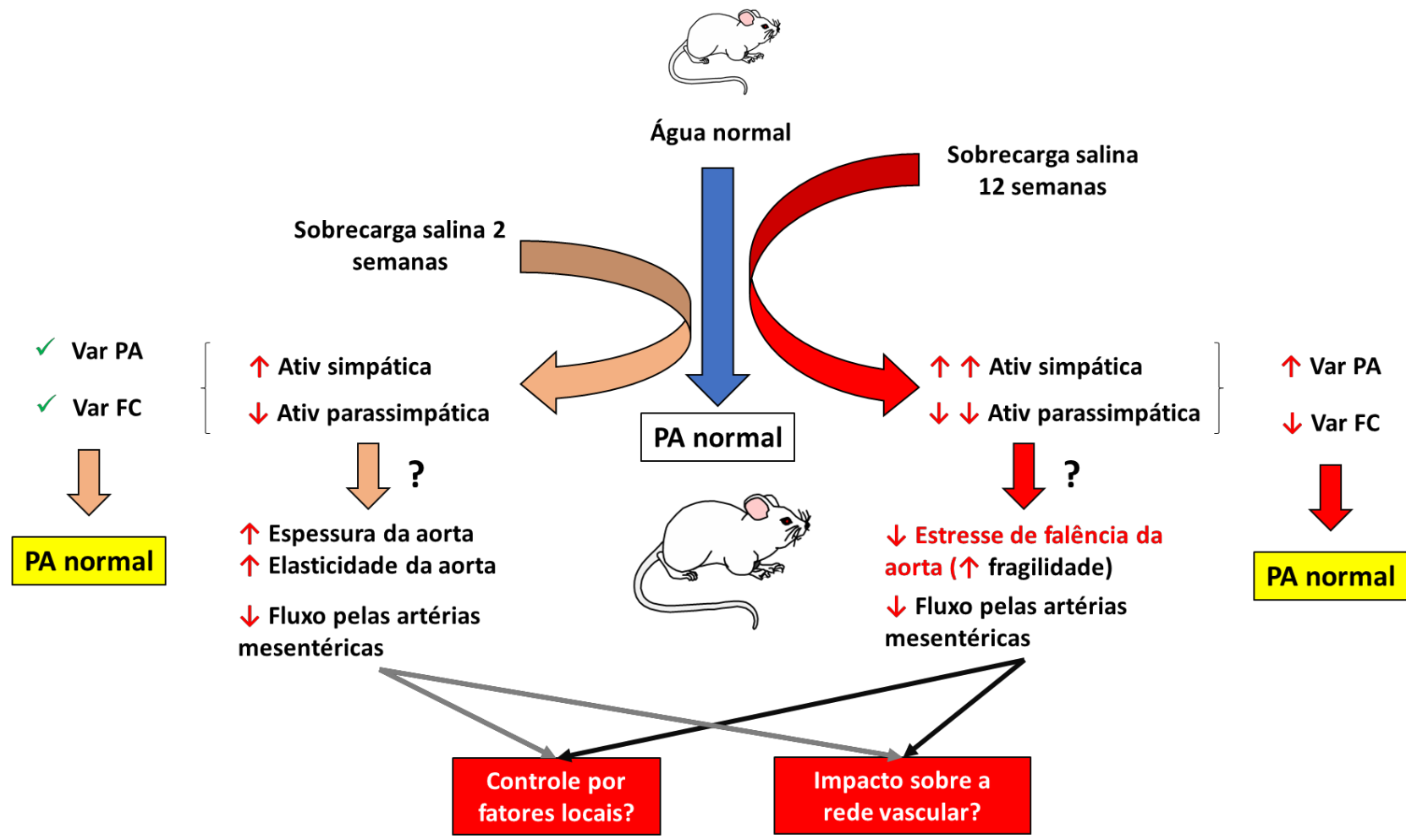

Figura 25: Resumo esquemático dos principais resultados obtidos no estudo hemodinâmico, no estudo de fluxo tecidual e no teste biomecânico da aorta, ressaltando os efeitos observados nos animais que receberam sobrecarga salina por período mais curto e crônico. Var: variabilidade; PA: pressão arterial; FC: frequência cardíaca; Baro: barorreceptores. 


\subsection{Estudo do remodelamento vascular}

Considerando os resultados anteriores, pode-se verificar que a sobrecarga salina impõe alterações autonômicas e de variabilidade de PA e de FC, embora a pressão arterial sistêmica se mantenha próxima de valores considerados normais. A ideia neste momento é de que o sistema vascular de remodele, de forma a promover ajustes de fluxo sanguíneo nos tecidos ou mude a produção de mediadores vasoativos locais. Isso sugere que ocorram adaptações estruturais importantes nestas artérias, como será discutido a seguir.

\subsubsection{Remodelamento da parede aórtica}

Ao avaliarmos a integridade tecidual da aorta, podemos verificar um aumento na área da túnica média nos animais tratados com sobrecarga salina (Figura 26A). A Figura 30 apresenta imagens representativas de aortas onde pode ser percebido este espessamento da túnica média. Embora este aumento não seja significante, seu significado biológico é relevante, visto que sugere uma possível mudança no fenótipo das células musculares lisas e justificaria um aumento da produção de matriz extracelular (como será mostrado posteriormente).

A razão adventícia/média dá uma ideia de como estas túnicas se comportam, visto que o aumento de uma destas ou ambas pode significar um enrijecimento vascular. A análise desta razão indica que o grupo tratado com sobrecarga salina por 2 semanas reduz a razão adventícia/média (Figura 26B), talvez em função do aumento da área da média observado, maior atividade proteolítica sobre as proteínas da adventícia ou ambos. Para grandes artérias elásticas como a aorta, não se espera que ocorram grandes alterações de espessura de parede, e talvez por isso não tenhamos obtido aumento estatisticamente significante. 

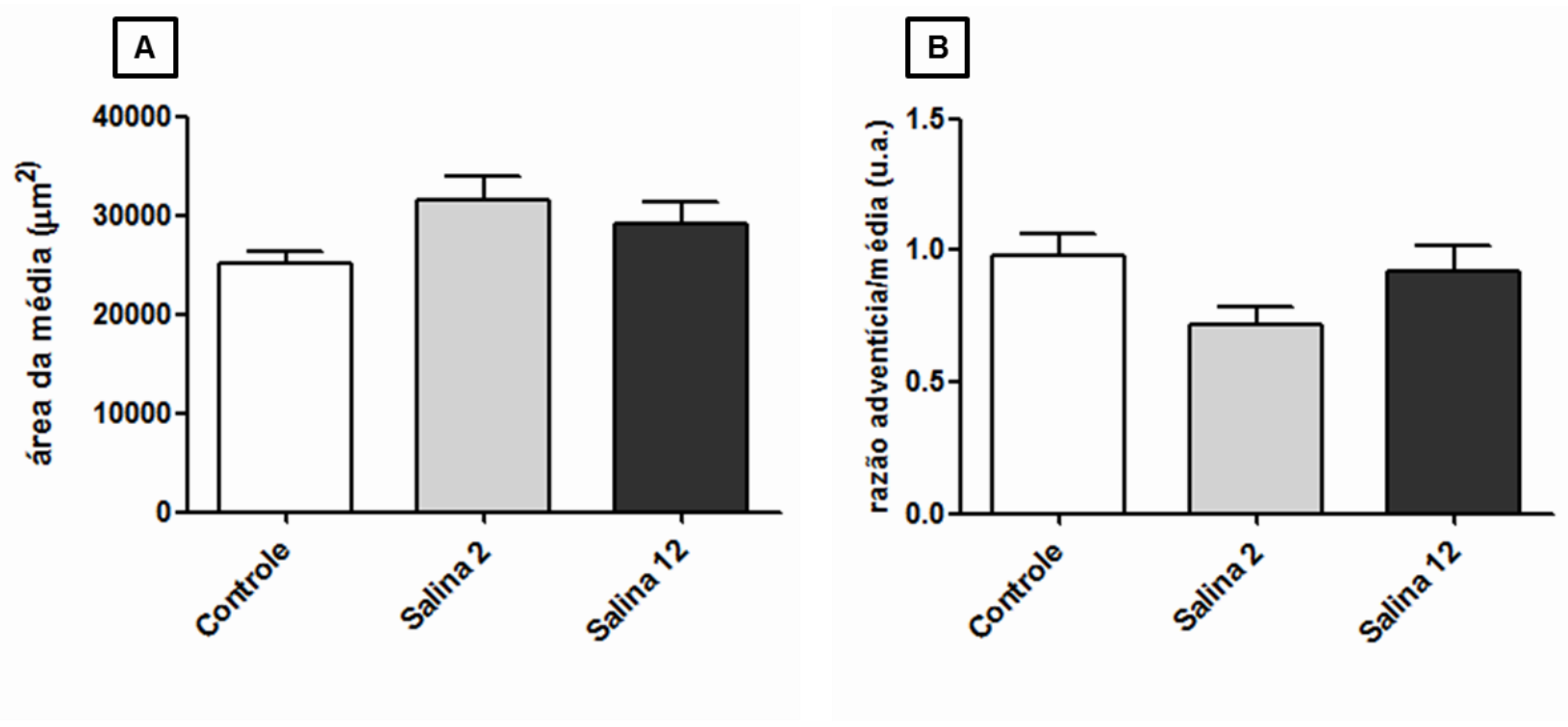

Figura 26: A: área da túnica média de cada grupo. Não foi encontrada alteração significante entre grupos. B: razão da área das túnicas adventícia/média de cada grupo, também não houve alteração significante.

5.5.2. Contagem das lamelas elásticas na Aorta

A contagem das lamelas elásticas é interessante em artérias como a aorta, pois dá uma ideia da capacidade de retorno elástico do vaso, que é de fundamental importância para artérias elásticas. No caso das artérias de pequeno calibre (de resistência ou musculares) não se espera ver alteração importante ou com efeitos funcionais nas lamelas elásticas. A contagem de lamelas elásticas na túnica média da aorta (Figura 27) mostrou aumento significante no grupo tratado com sobrecarga salina por 12 semanas $(+24,7 \%)$. Este achado chama a atenção, pois pode ser uma forma de ajuste encontrado para contrabalançar o aumento da deposição de fibras de colágeno nestes animais, como será descrito a seguir. A Figura 28 apresenta fotomicrografias representativas dos grupos estudados, mostrando aumento no múmero de lamelas elásticas na aorta do grupos Sal-12. 


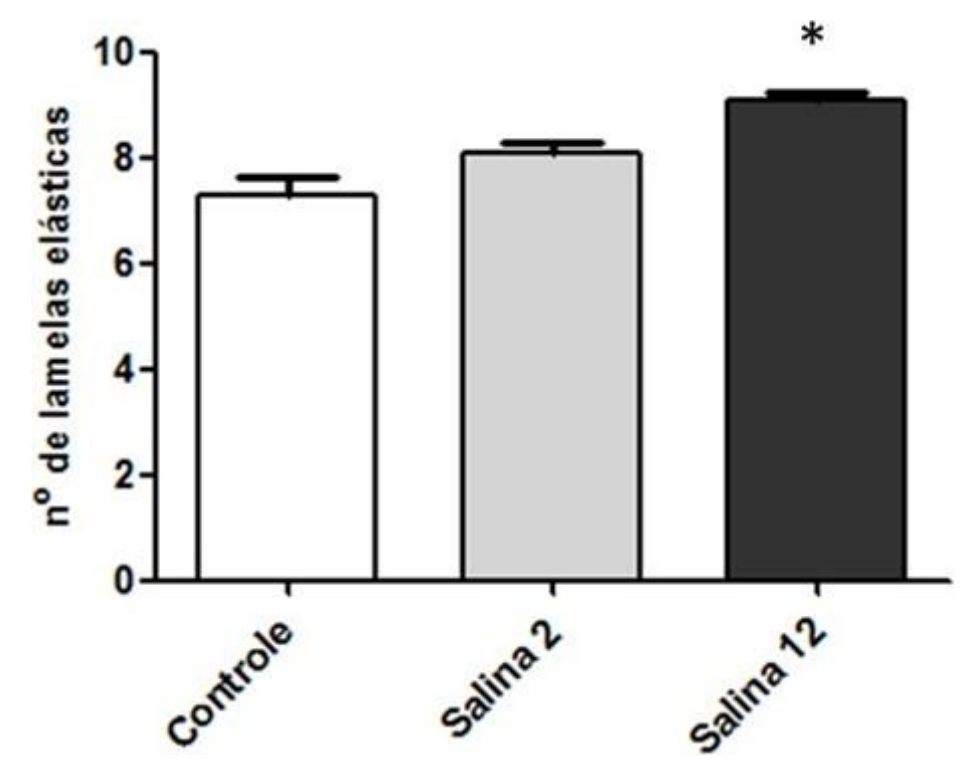

Figura 27: Número de lamelas elásticas na túnica média dos grupos estudados, mostrando aumento significante no grupo Sal- 12 em relação aos demais grupos. * $p \leq 0,05$, comparado ao grupo Controle.

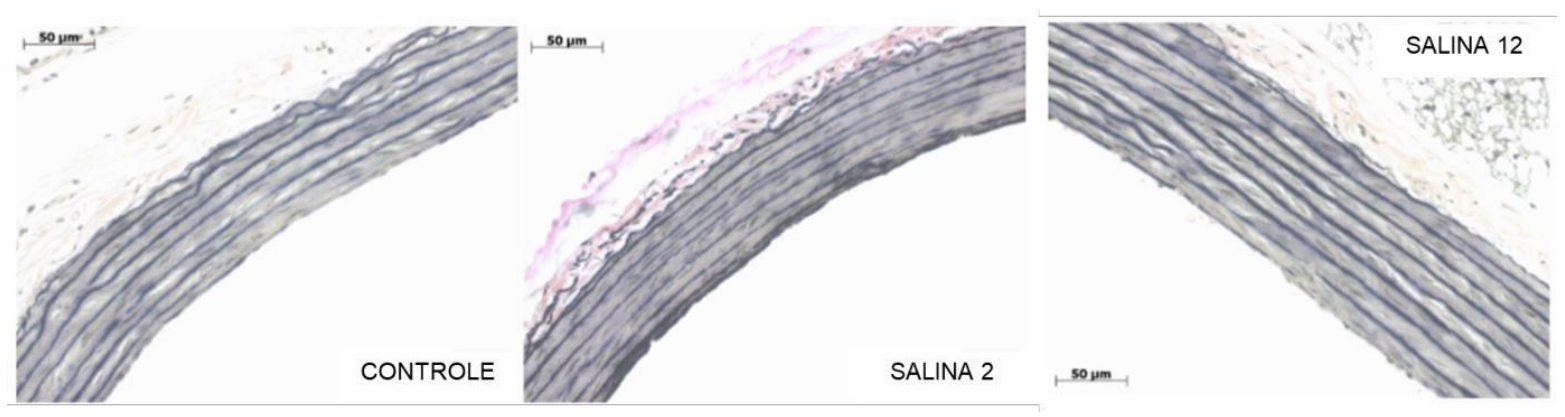

Figura 28: Fotomicrografias representativas de aortas coradas com Weigert Van-Gieson, enfatizando as lamelas elásticas.

\subsubsection{Estudo da deposição de colágenos fibrilares na Aorta}

Quando se avalia a deposição de fibras de colágeno na parede vascular, é possível perceber a presença de fibras mais espessas e mais delgadas. A presença de fibras delgadas pode ser devida à deposição de fibras de colágeno naturalmente mais finas como o colágeno tipo III ou a deposição recente de fibras que, com o tempo, formam conjuntos mais espessos, como colágeno tipo I. Neste caso, a identificação de qual o tipo de fibra depende de uma análise molecular. Contudo, a análise histológica pode se valer da capacidade das fibras de colágeno desviar a luz para se identificar fibras com espessuras diferentes. Assim, sob luz polarizada, as fibras 
delgadas aparecem com coloração verde, enquanto as fibras espessas (ou intermediárias) aparecem como coloração vermelha a amarela (respectivamente). A análise das aortas sob luz polarizada mostra uma mudança no padrão de tipos de fibras nos animais que recebem sobrecarga salina (Figura 29). É interessante observar que, comparados aos controles, os animais com sobrecarga salina passam a apresentar menor depósito de fibras delgadas e maior depósito de fibras espessas na túnica adventícia da aorta (Figura 31).

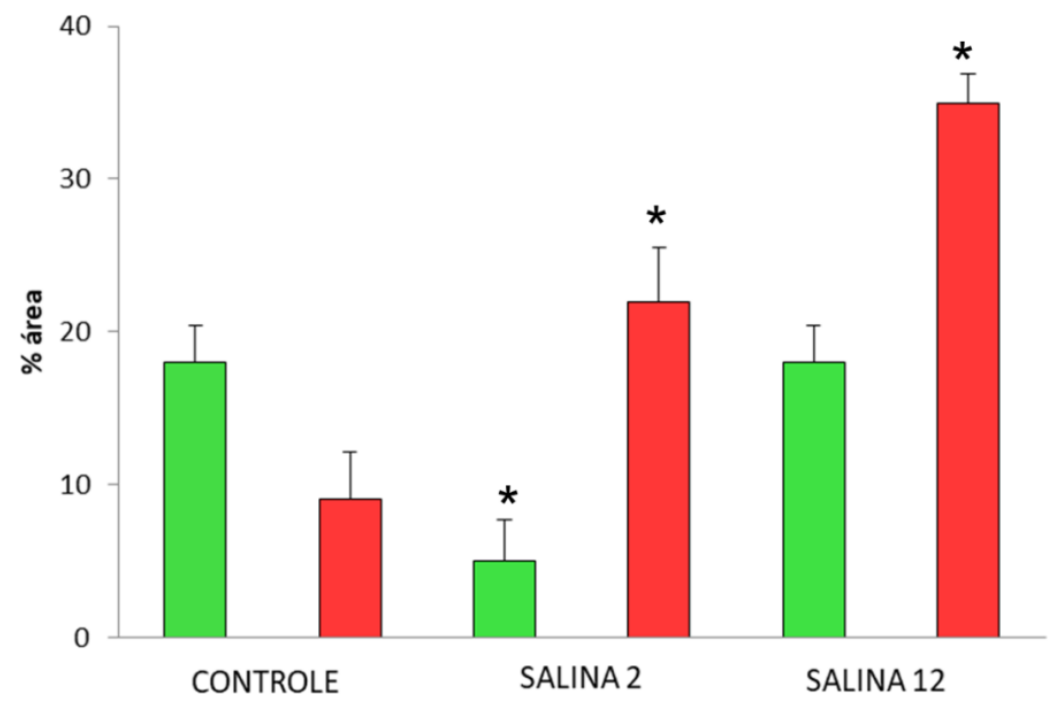

Figura 29: Porcentagem de área relativa às fibras delgadas (barras verdes) e espessas ou intermediárias (barras vermelhas) na túnica adventícia das aortas. Pode-se verificar um importante aumento da proporção de fibras espessas nos grupos com sobrecarga salina. * $p \leq 0,05$, comparado ao grupo Controle.

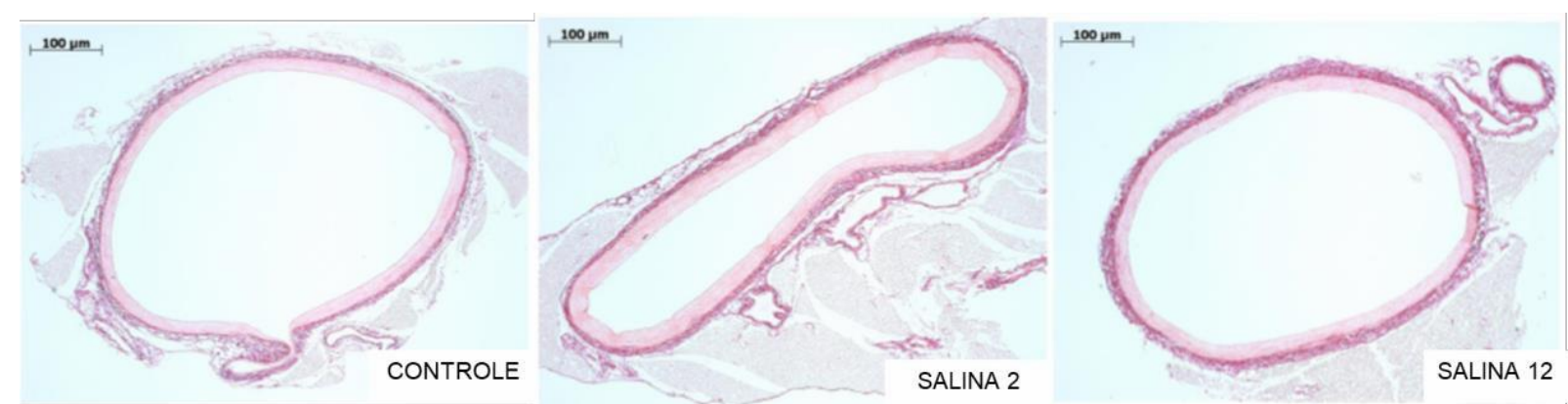

Figura 30: Fotomicrografias representativas de aortas coradas com Picrosirius, enfatizando a deposição de fibras colágenas. 

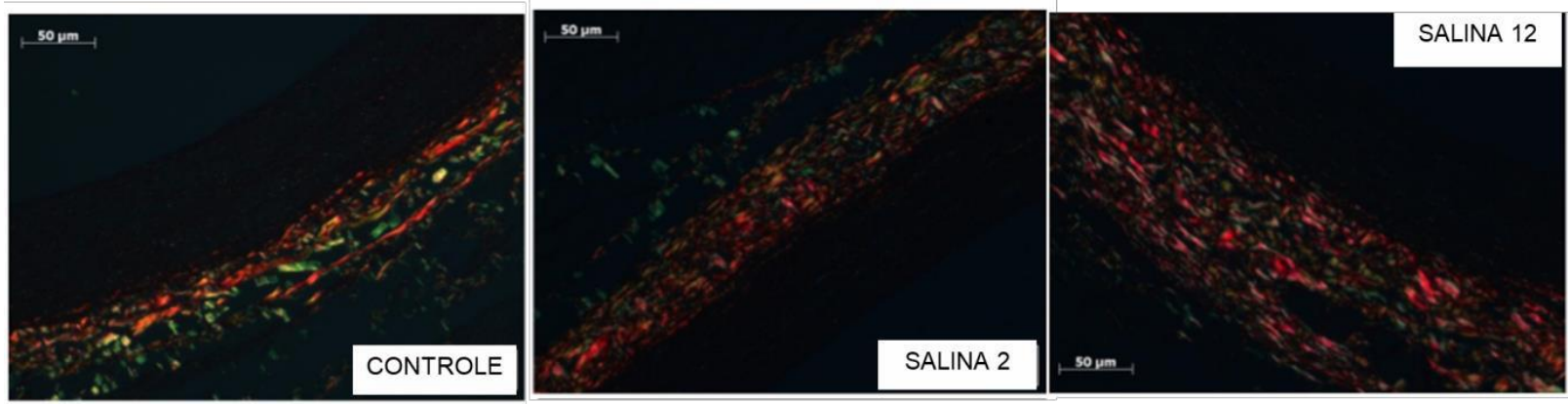

Figura 31: Fotomicrografias representativas de aortas coradas com Picrosirius sob a luz polarizada, enfatizando a deposição de fibras colágenas finas (verdes), intermediarias (amarelo) e espessas (vermelho).

\subsubsection{Avaliação dos colágenos não fibrilares na aorta}

O estudo dos colágenos por meio da coloração de picrossirius nos permite apenas analisar os colágenos fibrilares, como o colágenos I e III. Porém para uma melhor compreensão do remodelamento da matriz extracelular vascular, é importante que analisemos alguns tipos não fibrilares como o colágeno IV e VII. O colágeno IV se dispõem como uma rede compondo estruturalmente a lâmina basal, exercendo o papel de aderência e filtração. Já o colágeno VII é um colágeno que ancora as fibras de colágeno tipo I à lâmina basal (JUNQUEIRA E CARNEIRO, 2004).

Nosso estudo revelou que a sobrecarga salina induz a alteração na composição colágena na aorta. O colágeno IV apresenta-se aumentado nos dois grupos tratados com sobrecarga salina, sugerindo um aumento na malha que forma a lâmina basal vascular (Figura 32). Já a análise do colágeno VII mostra que as aortas dos animais tratados com sobrecarga salina apresentam importante redução em ambos os tempos de tratamento (Figura 34), sugerindo que exista um processo de desarranjo da matriz extracelular. Este desarranjo pode se dever à redução do colágeno VII e funcionar inclusive como estímulo ao aumento da deposição de colágenos fibrilares, como verificado. 
COL IV - Aorta

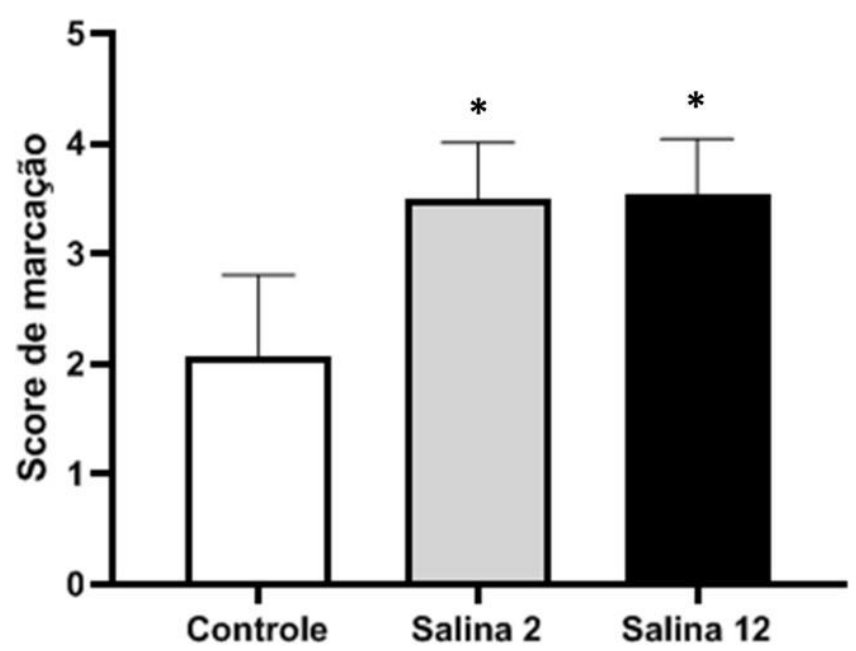

Figura 32: Score de marcação para Colágeno IV em aorta nos respectivos grupos. Os grupos tratados com sobrecarga salina se mostraram aumentados em relação ao grupo controle. ${ }^{*} p \leq 0,05$ em relação ao grupo controle.

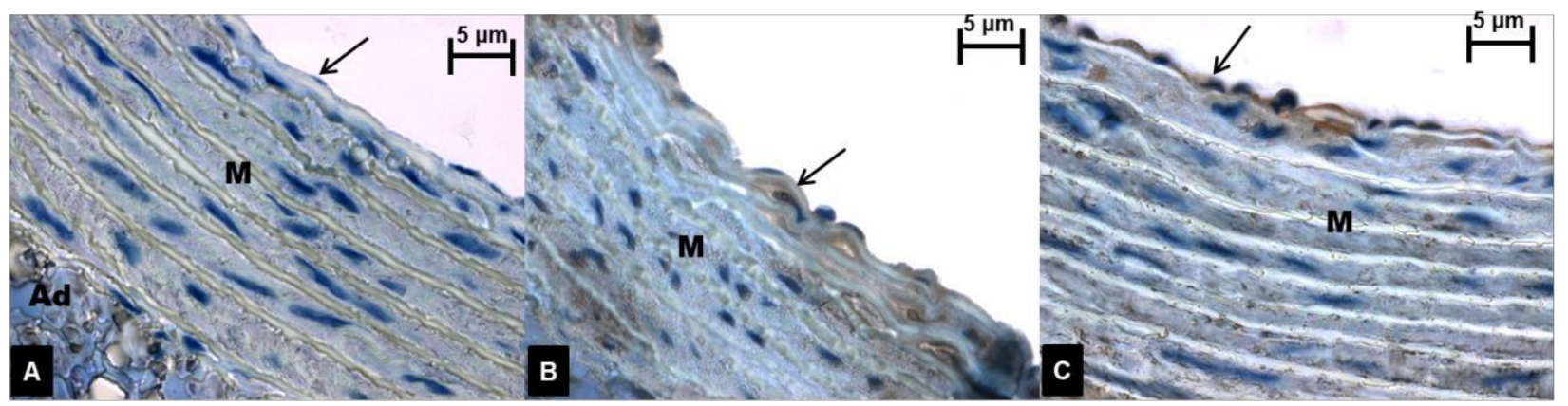

Figura 33: Fotomicrografias representativas da imunomarcação de Colágeno IV em aortas. $\mathrm{A}=$ Grupo Controle; $\mathrm{B}=$ Grupo Sal 2; $\mathrm{C}=$ Grupo Sal 12. 
COL VII - Aorta

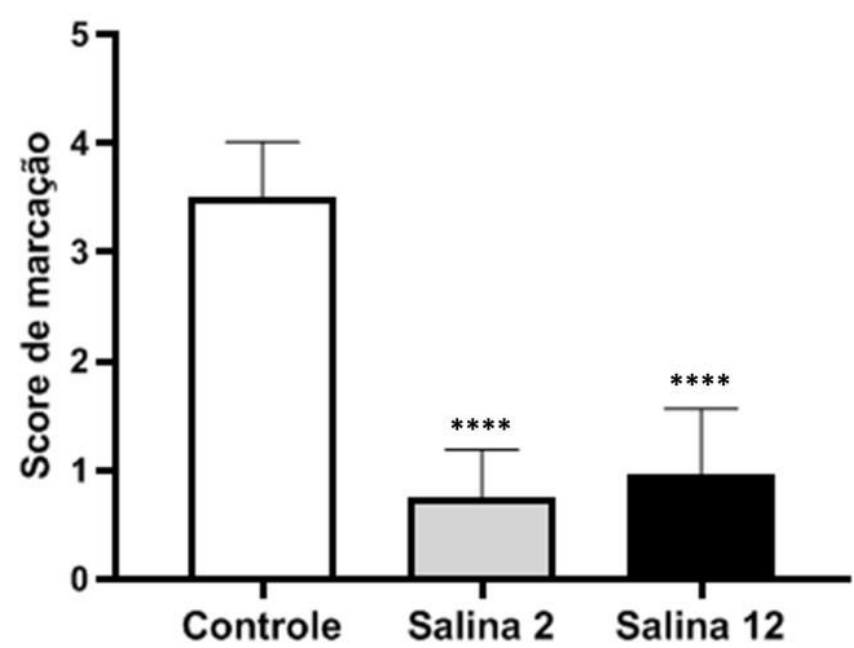

Figura 34: Score de marcação para Colágeno VII em aorta nos respectivos grupos. Os grupos tratados com sobrecarga salina se mostraram diminuídos em relação ao grupo controle. ${ }^{*} \mathrm{p} \leq 0,05$ em relação ao grupo controle.

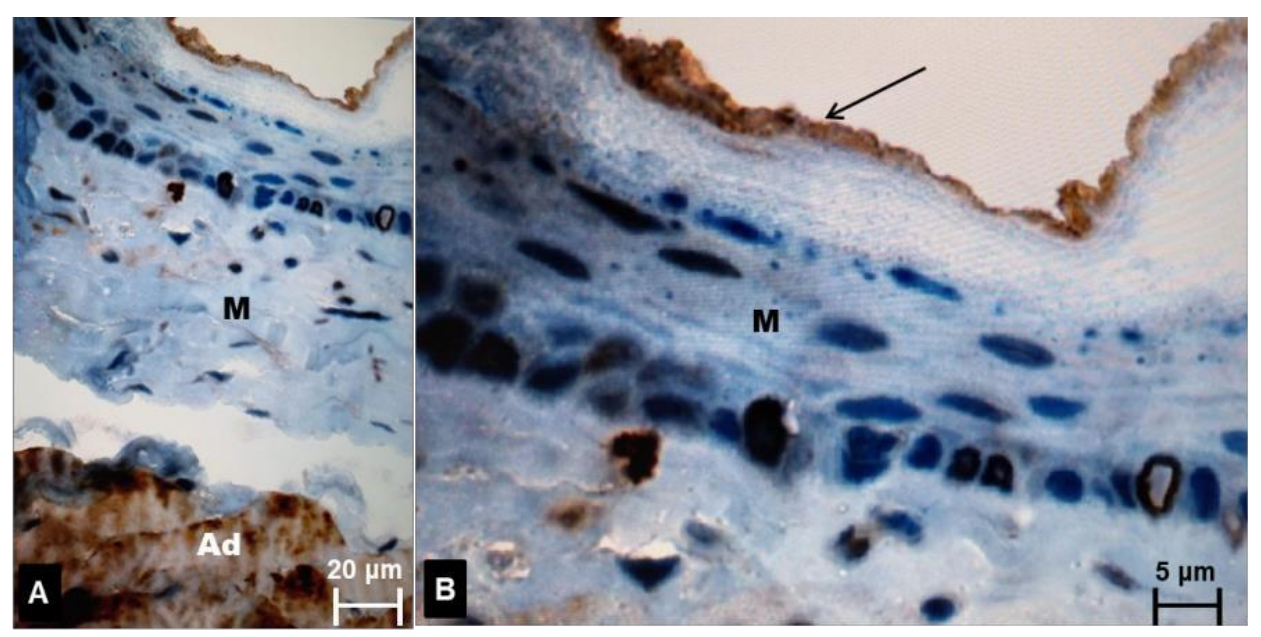

Figura 35: Fotomicrografia representativa da imunomarcação positiva para Colágeno VII em aortas. $A=$ Grupo Controle num menor aumento; $B=$ Grupo Controle num maior aumento. 
Ao se estudar artérias de resistência como as artérias mesentéricas, verificase uma resposta vascular a alterações de pressão arterial, levando ao aumento da espessura da parede vascular (AMARAL, et al. ,2000). No presente estudo, observamos um importante aumento na espessura da túnica média em ambos os grupos tratados com sobrecarga salina, mesmo que estes não apresentem elevação da pressão arterial, sugerindo o aumento da resistência periférica local. Embora a túnica média tenha aumentado nos dois grupos (Figura 36A), a razão adventícia/média também se apresenta aumentada, especialmente no grupo tratado com sobrecarga salina crónica (Sal-12). Este aumento sugere que a túnica adventícia apresenta um aumento tão grande a ponto de alterar a razão adventícia/média (Figura 36B).
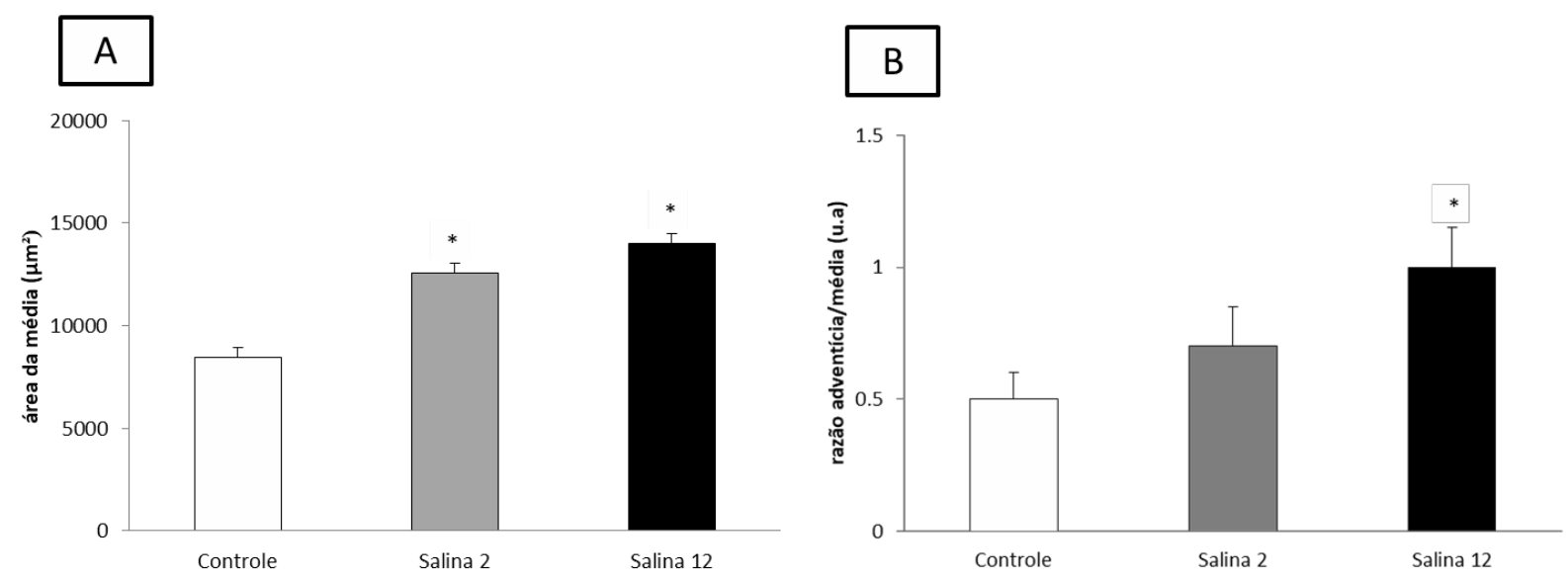

Figura 36: A: área da túnica média, mostrando aumento nos grupos tratados com sobrecarga salina; B: razão da área das túnicas adventícia/média de cada grupo, apresentando importante aumento no gripo Sal-12. * $p \leq 0,05$, comparado ao grupo Controle.

5.5.6. Estudo da deposição de colágenos fibrilares nas Artérias Mesentéricas

Muitos estudos têm mostrado que artérias de resistência são mais suscetíveis a um remodelamento diante de um fator estressante, como a sobrecarga salina (SANDERS, et al,. 2009). Neste sentido, considerando que a sobrecarga salina 
aumentou a área da túnica média e da túnica adventícia, é de se esperar um aumento na deposição de diversos elementos da matriz extracelular, especialmente os colágenos fibrilares.

Não somente observamos aumento de fibras colágenas na túnica adventícia, como também observamos alteração na composição entre fibras delgadas e espessas (Figura 37). Os animais tratados com sobrecarga salina apresentaram uma redução importante das fibras delgadas, sugerindo uma possível ativação de um processo de remodelamento arterial. Além disso, estes grupos que receberam sobrecarga salina também alteraram a porcentagem de fibras espessas, reforçando a ideia do remodelamento vascular. O grupos Sal-2 apresentou importante aumento da deposição de fibras espessas, sendo este aumento maior ainda no grupo Sal-12. Isso pode ser verificado observando as fotomicrografias representativas dos grupos (Figura 38).

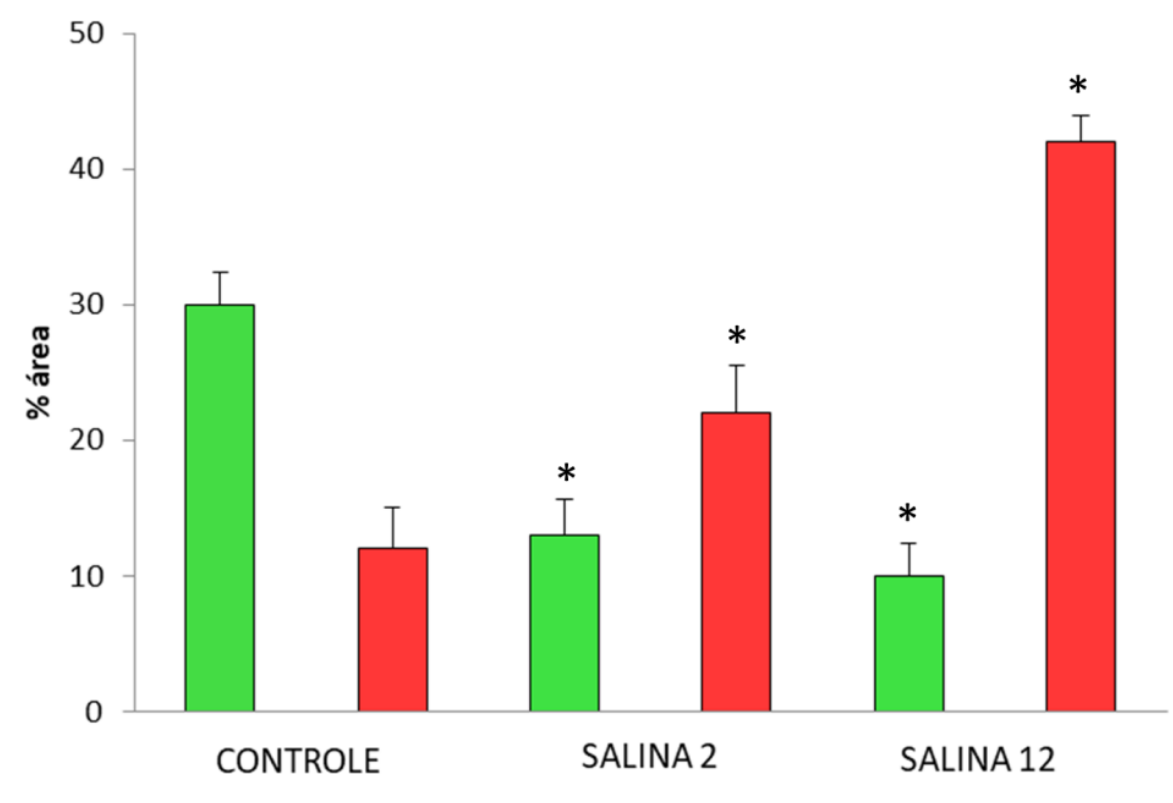

Figura_37: Porcentagem de área relativa às fibras delgadas (barras verdes) e espessas ou intermediárias (barras vermelhas) na túnica adventícia das artérias mesentéricas. Pode-se verificar um importante aumento da proporção de fibras espessas nos grupos com sobrecarga salina. ${ }^{*} p \leq 0,05$, comparado ao grupo Controle. 


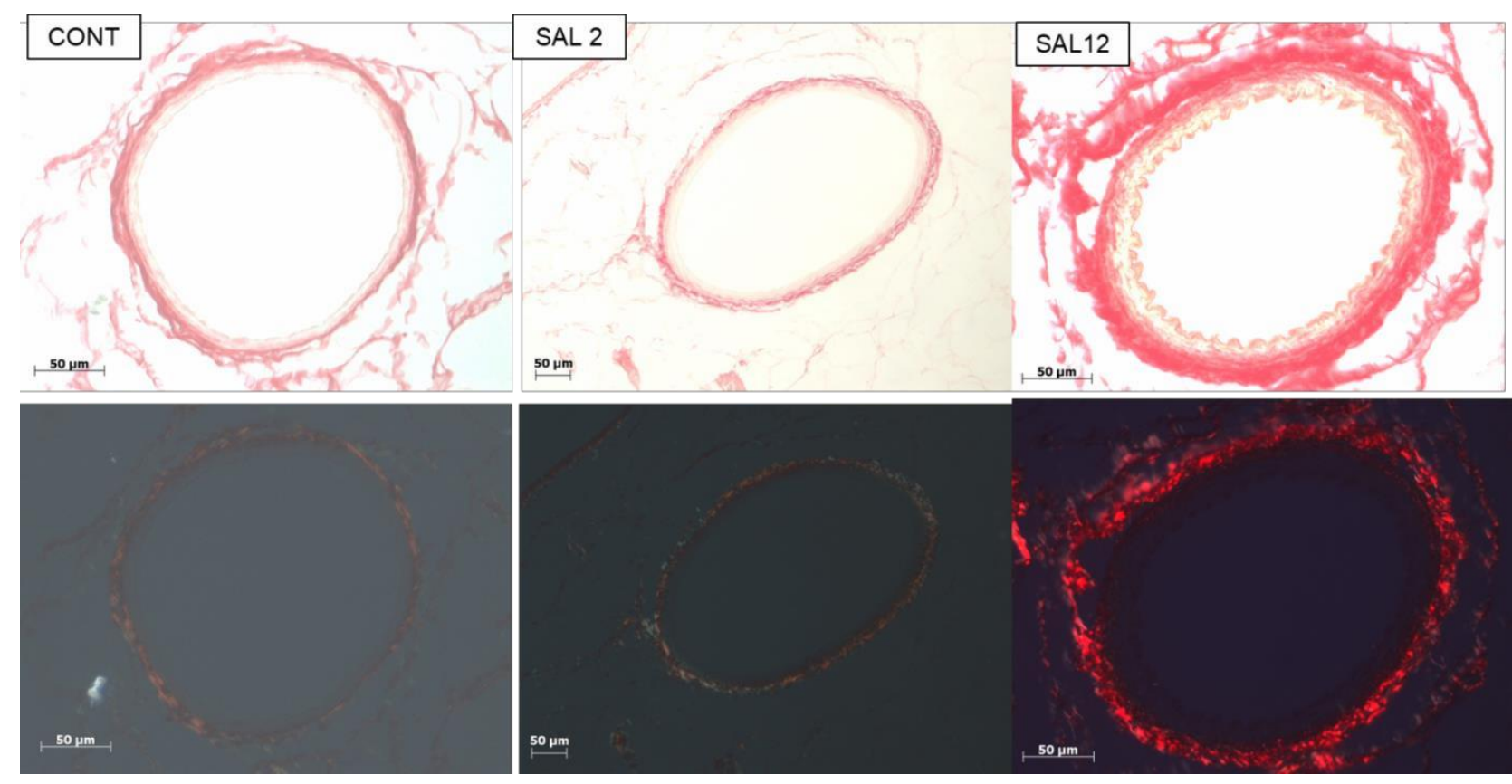

Figura 38 - Fotomicrografias representativas das artérias mesentéricas coradas para Picrossirius, mostrando aumento significante no grupo Sal-12 em relação aos demais grupos.

Se compararmos as respostas obtidas pelos dois tipos de artérias, observaremos que os vasos de condutância como as aortas parecem não responder tanto e tão imediatamente quanto os vasos de resistência como as artérias mesentéricas. Porém isso já é esperado, como já mencionado anteriormente, os vasos de resistência são vasos mais suscetíveis a alterações, no entanto essa resposta da aorta diante de um estresse não pressórico, nos chama a atenção.

A aorta parece tentar contrabalancear a resposta pressora que os vasos de resistência estão exercendo, por outro lado, alguns estudos vêm mostrando que a sobrecarga salina parece de alguma forma fragilizar os vasos, tornando-os mais suscetíveis a um aneurisma (NISHIJO et al., 1998; GRIGOROVA et al, 2016), nossos dados foram ao encontro desses, ou seja, as aortas apresentam maior complacência porém com menor resistência. 
A análise da deposição dos colágenos IV e VII nas artérias mesentéricas mostrou que a a sobrecarga salina age de forma diferente do observado nas aortas. Nestas artérias de resistência, ocorre aumento do colágeno IV após 2 semanas de sobrecarga salina, sendo este aumento mais intenso no grupo tratado cronicamente (Sal-12, Figura 39 e 40). Por outro lado, a deposição de colágeno VII parece muito menor nas artérias mesentéricas, que, aparentemente, não se modifica com a sobrecarga salina (Figura 41).

\section{COL IV - Artéria Mesentérica}

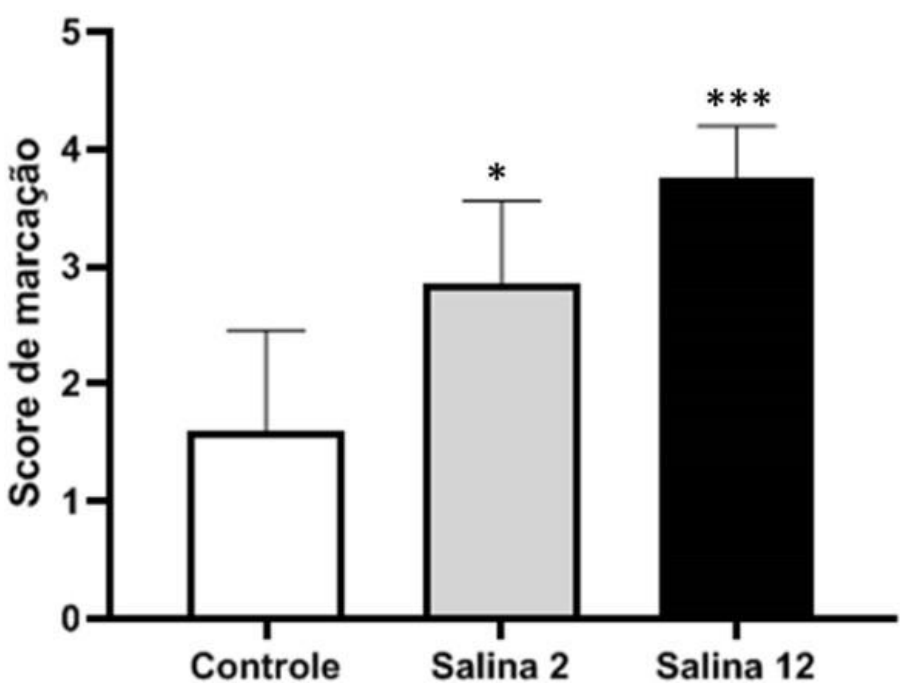

Figura 39: Score da imunomarcação para colágeno IV em artérias mesentéricas nos respectivos grupos, mostrando aumento significante nos grupos tratados em relação ao grupo controle. ${ }^{*} p \leq 0,05$ em relação ao grupo controle.

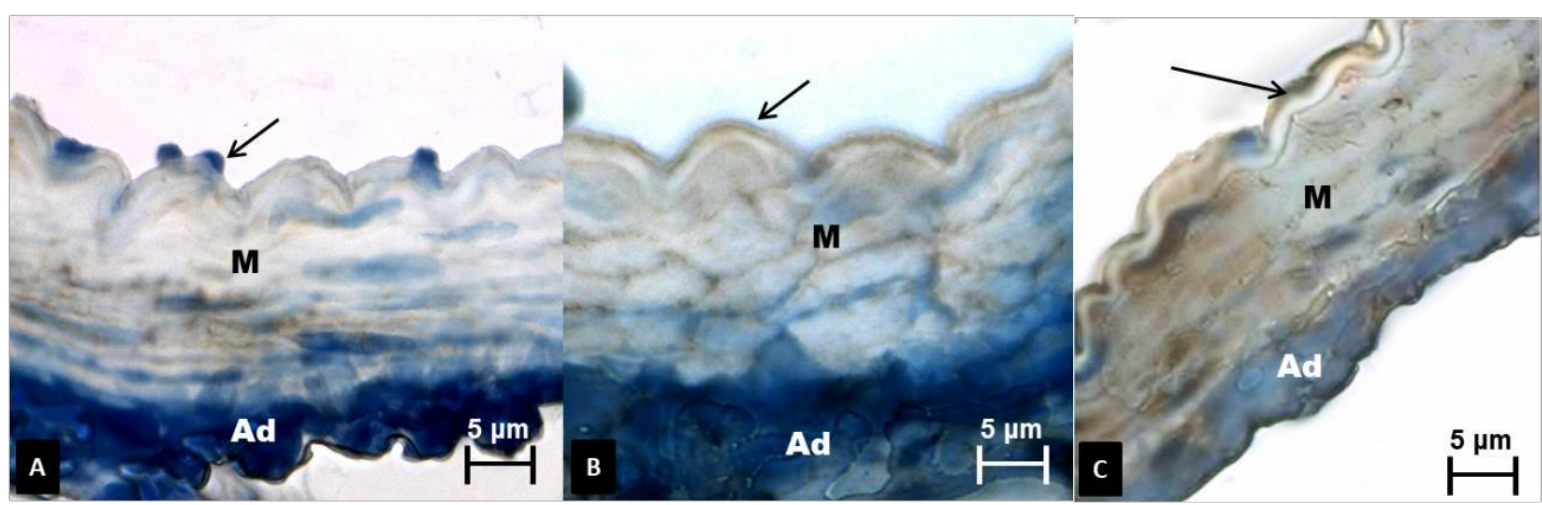

Figura 40: Fotomicrografia representativa da imunomarcação de Colágeno IV (setas marcação positiva) em artérias mesentéricas. $A=$ Grupo Controle; $B=G r u p o$ Sal 2; $\mathrm{C}=$ Grupo Sal 12 


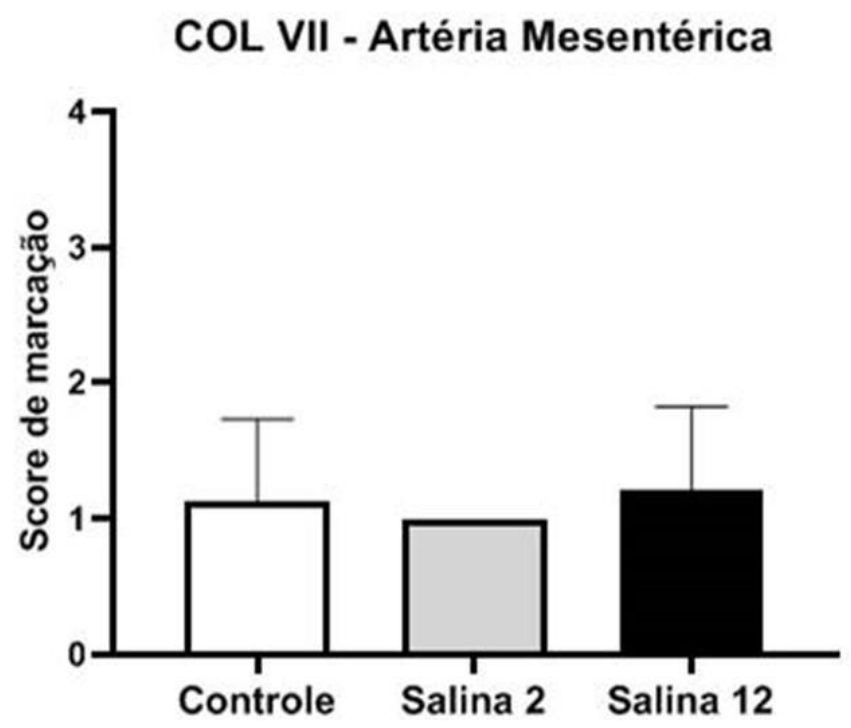

Figura 41: Score da imunomarcação para colágeno VII em artérias mesentéricas nos respectivos grupos, não mostrando alterações significantes entre os grupos.

\subsubsection{Análise das metaloproteinases de matriz na parede vascular}

Considerando as alterações na parede vascular, seja na espessura da túnica média (sugerindo alteração celular), seja na composição da matriz extracelular (MEC), parece lógico pensar que enzimas responsáveis pela degradação de elementos da MEC sejam produzidas. Estas enzimas, conhecidas como metaloproteinases de matriz (MMPs), apresentam um mecanismo próprio de regulação tecidual, sendo as mais abundantes nos tecidos cardiovasculares a MMP- 2 e a MMP-9. Assim, as MMPs farão a degradação dos componentes fibrilares da matriz extracelular, principalmente fibras de colágeno.

A forma mais eficiente de entender a atividade deste mecanismo se faz medindo a atividade destas enzimas, através de sua ação como colagenase pelo método da zimografia. Ao avaliarmos a ação destas enzimas em aortas e artérias mesentéricas, não encontramos atividade de MMP-9. Nesse caso, alguns estudos demonstraram que ela se faz presente em situações inflamatórias, sendo muito comum na hipertensão arterial (DELEON-PENNELL et al., 2015; YABLUCHANSKIY, et al., 2013). Contudo, no presente estudo, a ausência da elevação da pressão arterial pode ter influenciado este resultado. 
Quando avaliamos a MMP-2, verificamos aumento da atividade na aorta após 2 semanas de sobrecarga salina, enquanto as artérias mesentéricas mostraram aumento da atividade nos dois tempos de sobrecarga salina (Figura 42). Embora estes resultados da zimografia não tenham sido estatisticamente significantes, não podemos ignorar que há uma ação biológica relevante e que se relaciona com as modificações da MEC observadas.

As medidas da atividade das MMPs feitas pela zimografia ocorreram também em outros tecidos, para compreensão da atividade das metaloproteinases. Porém, como não se tratava de nosso objetivo principal, estes outros resultados são apresentados no Anexo III.
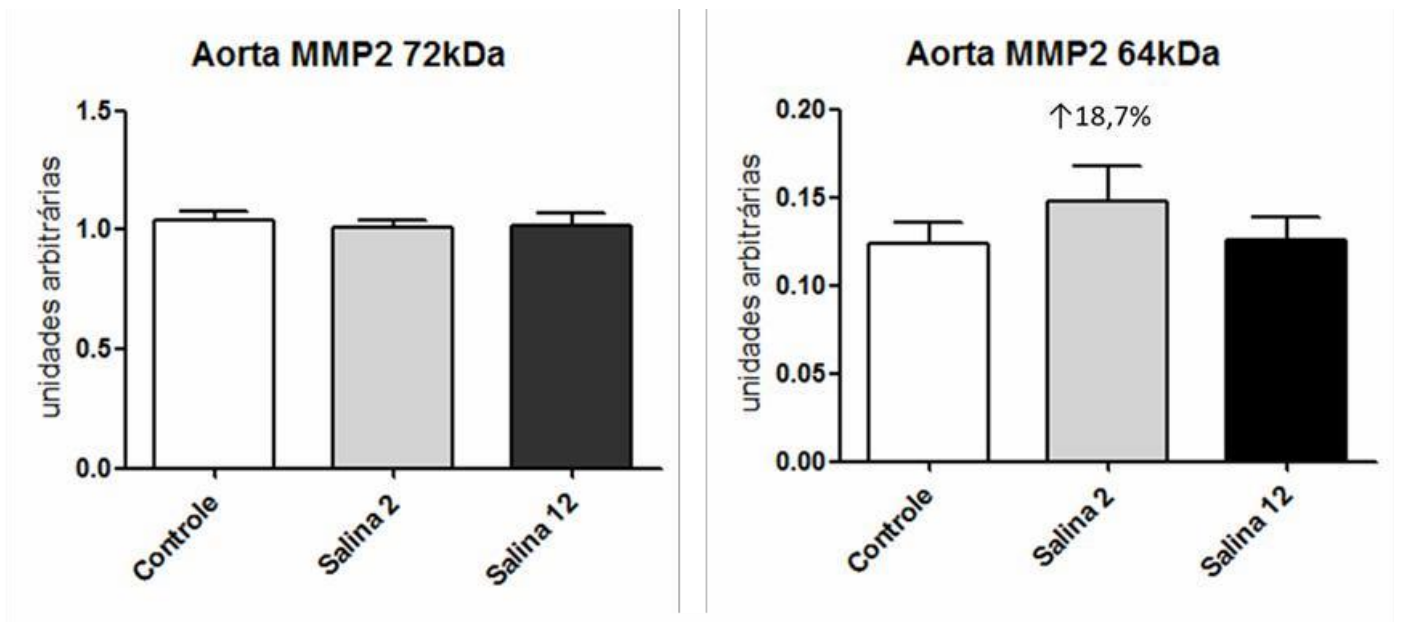

Mesenterı MMP2 72kDa

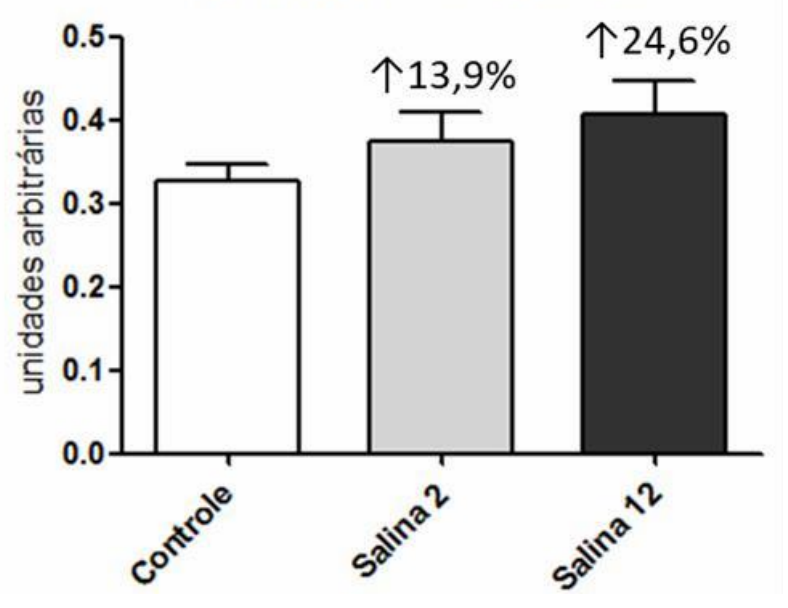

Figura 42: Análise da zimografia em aorta e artérias mesentéricas, mostrando aumento nos grupos que receberam sobrecarga salina, embora não significante. 
A análise pela zimografia foi realizada em aorta e artérias mesentéricas junto com tecidos adjacentes, especialmente tecido adiposo perivascular. Embora os resultados não tenham sido significantes, pode-se esperar que o tecido adjacente tenha interferido no resultado, especialmente pelo tamanho reduzido destes tecidos.

Por isso, decidimos avaliar a presença da MMP-2 nestes vasos. Ao analisarmos a presença de MMP2 tecidual, observamos que tanto em aortas como em mesentéricas, ela se mostra aumentada em ambos os grupos tratados com sobrecarga salina, sendo estatisticamente diferente nos animais tratados com solução salina por 2 semanas (Figuras 43, 44 e 45).

\section{MMP-2 - Aorta}

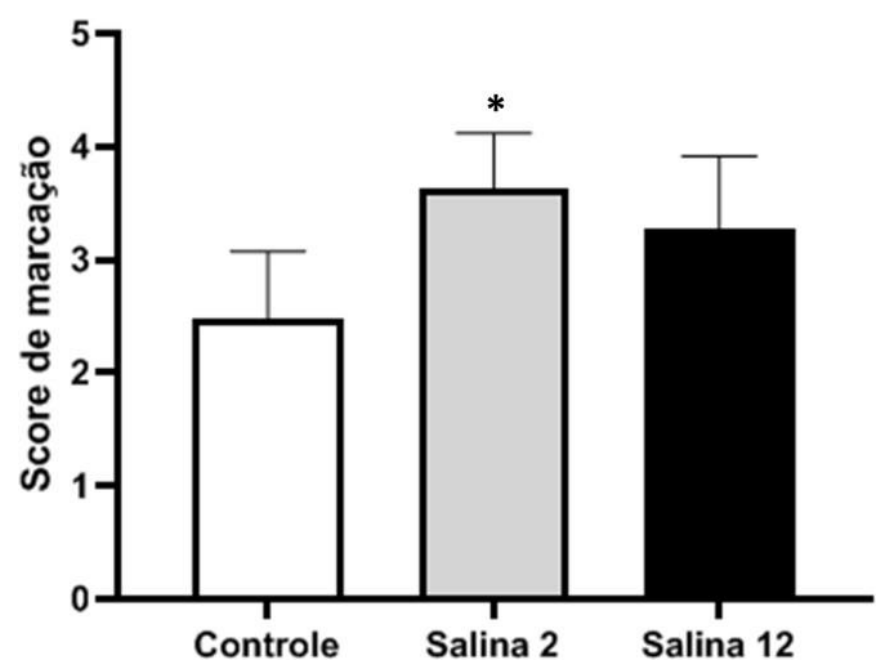

Figura 43: Score de imunomarcação para MMP-2 em aorta nos respectivos grupos. O tratamento com sobrecarga salina induz ao aumento de MMP2 após 2 semanas. ${ }^{*} \mathrm{p} \leq 0,05$ quando comparado ao grupo controle. 


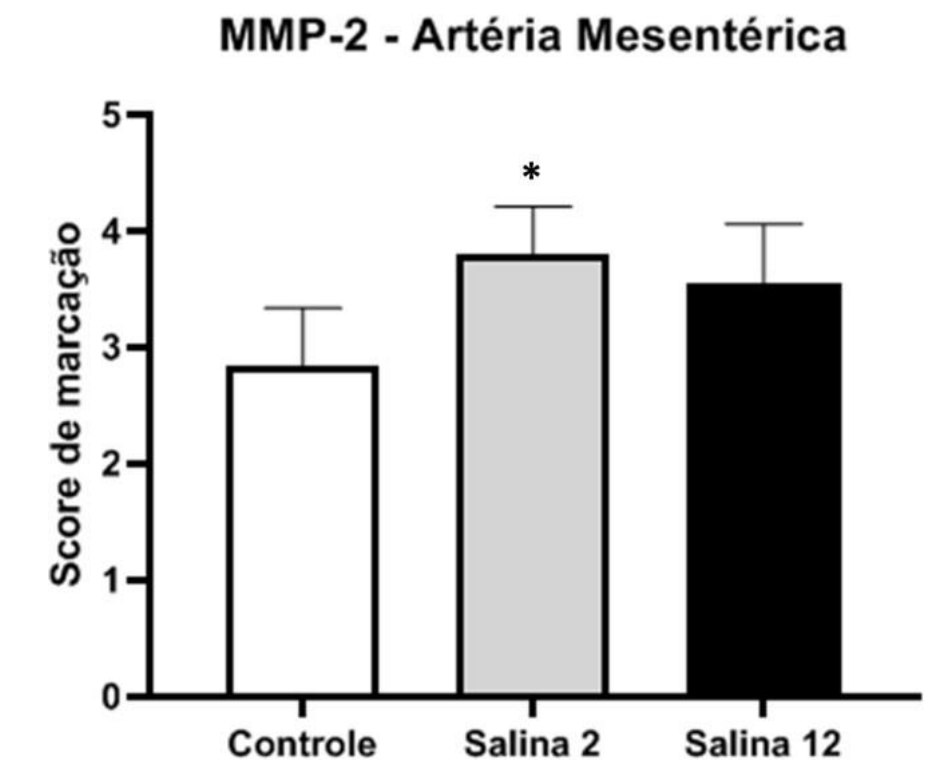

Figura 44: Score de imunomarcação para MMP-2 em artérias mesentéricas nos respectivos grupos. O tratamento com sobrecarga salina induz ao aumento de MMP2 após 2 semanas. ${ }^{*} \mathrm{p} \leq 0,05$ quando comparado ao grupo controle.

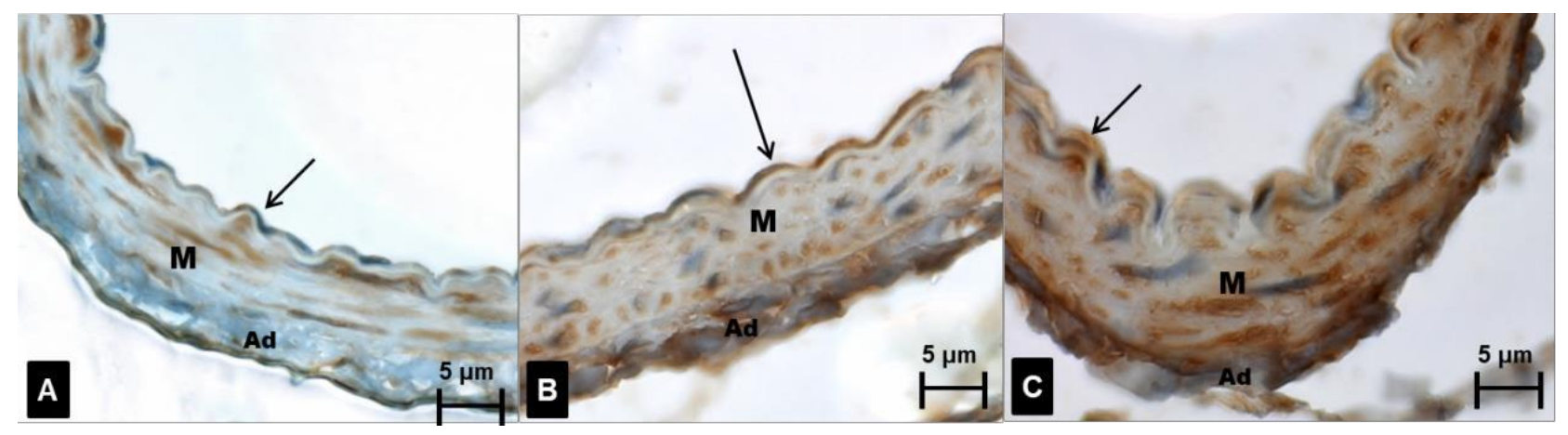

Figura 45: Fotomicrografias representativas de imunomarcação para MMP2 em artérias mesentéricas. As setas mostram a marcação positiva para MMP2. A=Grupo Controle; B= Grupo Sal 2; C= Grupo Sal 12

5.5.9. Avaliação de marcadores teciduais para fibrose

Como se pode observar, a sobrecarga salina, mesmo na ausência de hipertensão arterial, induz um remodelamento vascular. Acreditamos que seja devido a esse remodelamento que o animal ainda consiga manter seus níveis pressóricos dentro da normalidade. Diante de tal remodelamento, se torna importante verificar que possíveis mediadores estão envolvidos neste processo. 
O fator de crescimento transformante $\beta$ (TGF- $\beta$ ) regula múltiplos processos biológicos, incluindo desenvolvimento embrionário, diferenciação celular, regulação imunológica, cicatrização e inflamação, além do remodelamento vascular, uma vez que é por meio dele que é ativada uma das principais enzimas envolvidas na manutenção da matriz extracelular, a MMP (GOUMANS, et al., 2018; LICHTMAN, et al., 2015; CLARK, et al., 1998).

A análise da marcação de TGF $\beta$ nas aortas e artérias mesentéricas nos leva a crer que a sobrecarga salina não alterou sua produção e liberação no tecido. Tal resultado não significa que o TGF $\beta$ não esteja envolvido no remodelamento vascular. Alguns estudos mostraram a ação do TGF $\beta$ de maneira aguda (KHALIL, 1999). Nosso grupo mostrou recentemente que o TGF $\beta$ responde agudamente à angiotensina II $\mathrm{e}$ pode participar do processo inflamatório de forma aguda em artérias de animais normotensos (resultados não publicados). Além disso, verificou- se que o TGF $\beta$ parece estar relacionado à deposição de colágeno perivascular em artérias de resistência em animais normotensos (Oliveira, 2016). Os resultados obtidos sugerem que, nos tempos avaliados, a sobrecarga salina não parece alterar a produção de TGF $\beta$ (Figuras 46, 47, 48 e 49); contudo, outros estudos avaliando momentos mais precoces e talvez mais tardios possam ser necessários para confirmar esta hipótese.

TGF- $\beta$ - Aorta

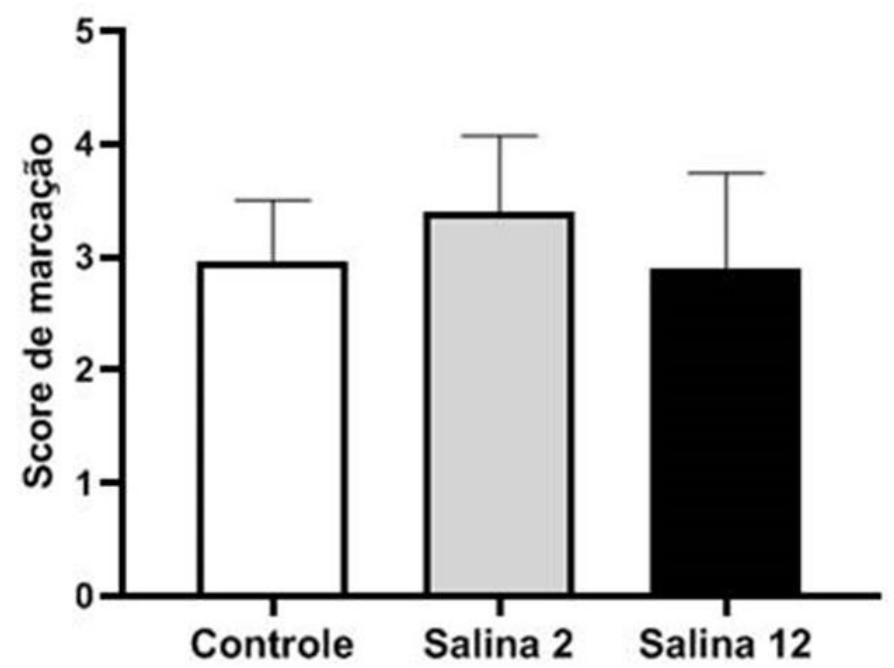

Figura 46_: Análise da marcação positiva para TGF $\beta$ obtida pela imunohistoquímica, mostrando a ausência de alterações importantes decorrentes da sobrecarga salina nos tempos estudados. 


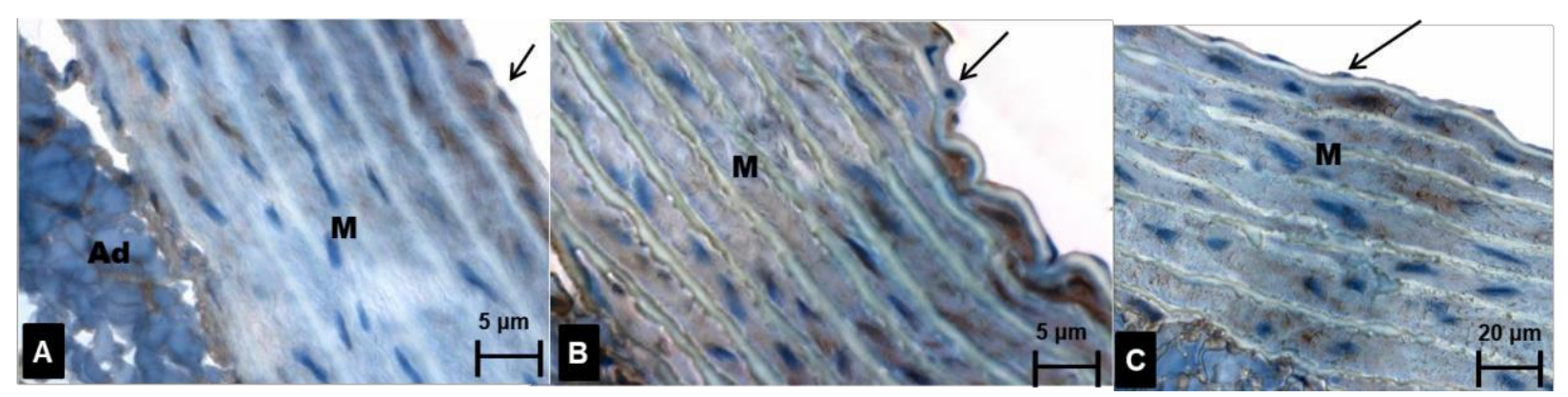

Figura 47: Fotomicrografias representativas da imunohistoquímica para TGF $\beta$ nas aortas nos grupos estudados. As setas mostram a marcação positiva, aumentada nos grupos tratados com sobrecarga salina. $A=$ Grupo Controle; $B=$ Grupo Sal 2; $C=$ Grupo Sal12

TGF- $\beta$ - Artéria Mesentérica

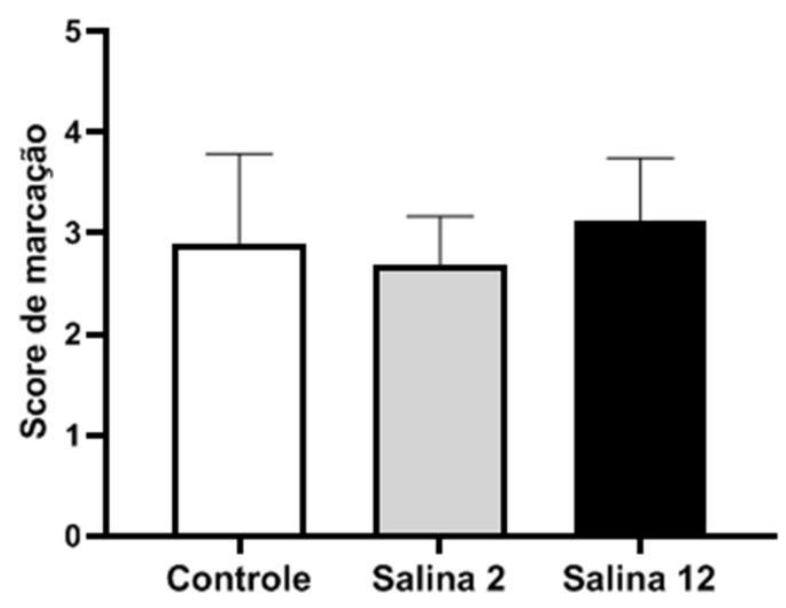

Figura 48: Análise da marcação positiva para TGF $\beta$ obtida pela imunohistoquímica, mostrando a ausência de alterações importantes decorrentes da sobrecarga salina nos tempos estudados.

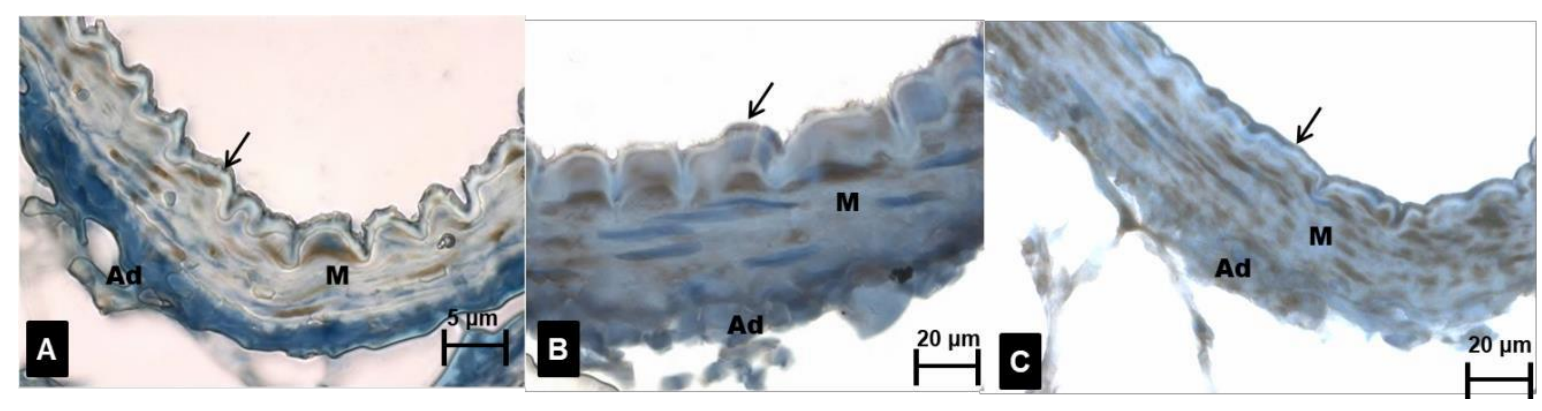

Figura_49: Fotomicrografias representativas da imunohistoquímica para TGF $\beta$ nas aortas nos grupos estudados. As setas mostram a marcação positiva, aumentada nos grupos tratados com sobrecarga salina. $A=$ Grupo Controle; $B=$ Grupo Sal 2; $C=$ Grupo Sal12 
Outra proteína que tem sido associada com o remodelamento vascular e a deposição de colágeno vascular é a galectina 3. Esta proteína ainda é pouco estudada na associação com doenças cardiovasculares, embora muito estudada na associação com o câncer (GEHLKEN, et al., 2018; THIJSSEN, et al., 2015). As galectinas são uma familia de proteínas com diversas funções como adesão celular, migração, resposta imune inata e adquirida, angiogênese, tumorigênese, e apoptose (VIGUIER et al., 2014).

Quanto à matriz extracelular, a galectina 3 está associada à interação célulamatriz modulando a fixação e o desprendimento das células através da ligação com componentes da MEC presentes nos tecidos como laminina, fibronectina, elastina e colágeno IV, entre outros (FUNASAKA et al., 2014). Todas estas ações nos chamaram a atenção para a necessidade de um estudo mais aprofundado da sua participação nas respostas teciduais induzidas pela sobrecarga salina, especialmente considerando a modificação na deposição de colágenos induzida pela sobrecarga salina.

Interessantemente, observamos que a galectina 3 parece estar associada ao remodelamento vascular induzido pela sobrecarga salina. Na aorta, verificamos que a sobrecarga salina induz aumento da gelactina 3 já após 2 semanas de tratamento, sendo este aumento ainda maior após o tratamento crônico (Sal-12), como pode ser visto nas Figuras 50 e 51. Quando avaliamos as artérias mesentéricas, podemos verificar que a galectina 3 se encontra aumentada em ambos os grupos que receberam sobrecarga salina (Figuras 52 e 53).

Alguns estudos têm demonstrado a relação da galectina $3 \mathrm{com}$ a fibrose tecidual, mostrando que esta seria um dos mediadores do efeito pró-fibrótico da aldosterona. Além disso, foi demonstrada a co-localização de galectina com macrófagos e fibroblastos, responsáveis também pelo remodelamento de MEC vascular e pelo processo de fibrose (LIN et al., 2014; HARVEY et al., 2016). A galectina parece estar também associada a alterações vasculares no envelhecimento e estresse oxidativo (BOER et al., 2010). 


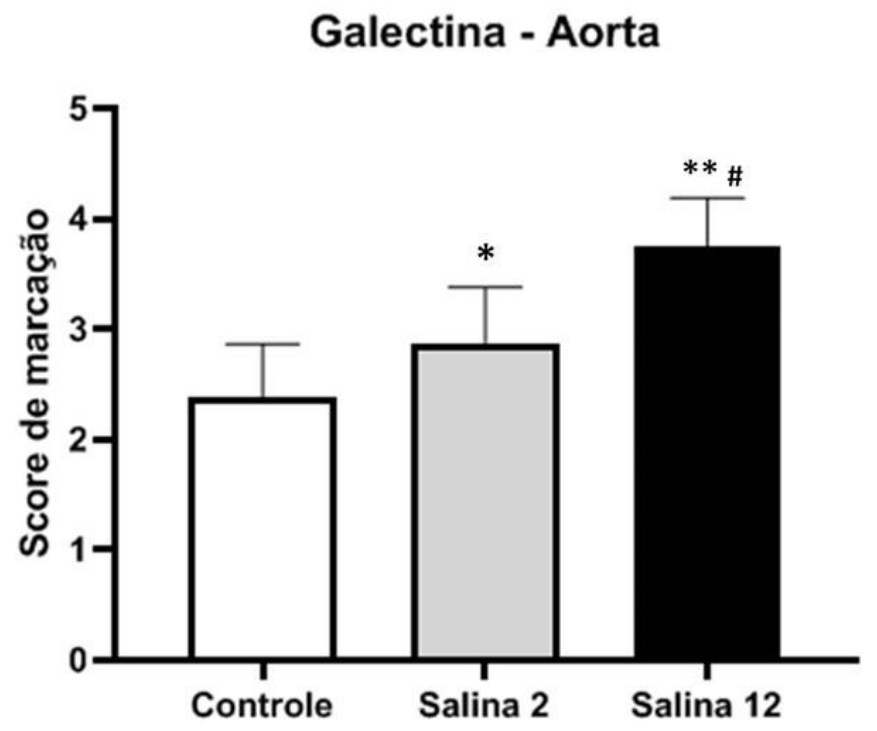

Figura 50 - Análise da marcação positiva para galectina 3 obtida pela imunohistoquímica, mostrando aumento nos grupos Sal-2 e Sal-12 tanto em aortas como em artérias mesentéricas. ${ }^{*} p \leq 0,05$, comparado ao grupo Controle. \# $p \leq 0,05$, comparado ao grupo Sal-2.

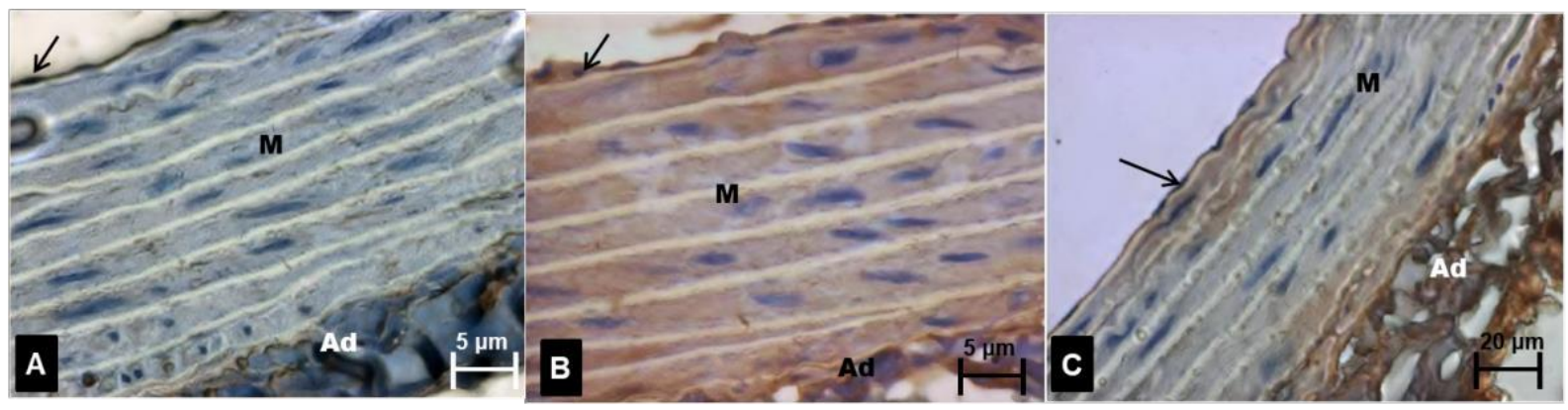

Figura 51: Fotomicrografias representativas da imunohistoquímica para galectina 3 nas aortas nos grupos estudados. As setas mostram a marcação positiva, aumentada nos grupos tratados com sobrecarga salina. $A=$ Grupo Controle; $B=$ Grupo Sal 2; $C=$ Grupo Sal 12. 


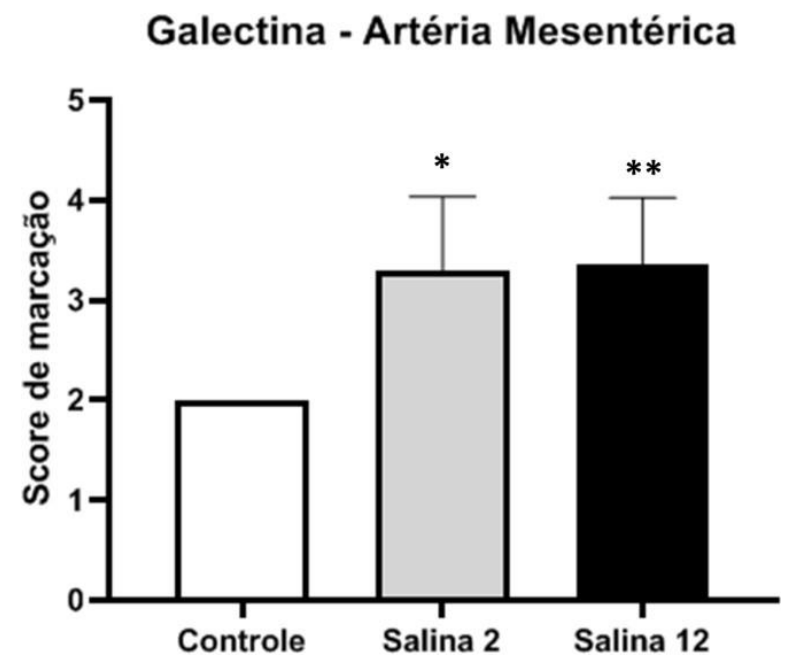

Figura 52_: Análise da marcação positiva para galectina 3 obtida pela imunohistoquímica, mostrando aumento nos grupos Sal-2 e Sal-12 tanto em aortas como em artérias mesentéricas. * $p \leq 0,05$, comparado ao grupo Controle. \# $p \leq 0,05$, comparado ao grupo Sal-2.

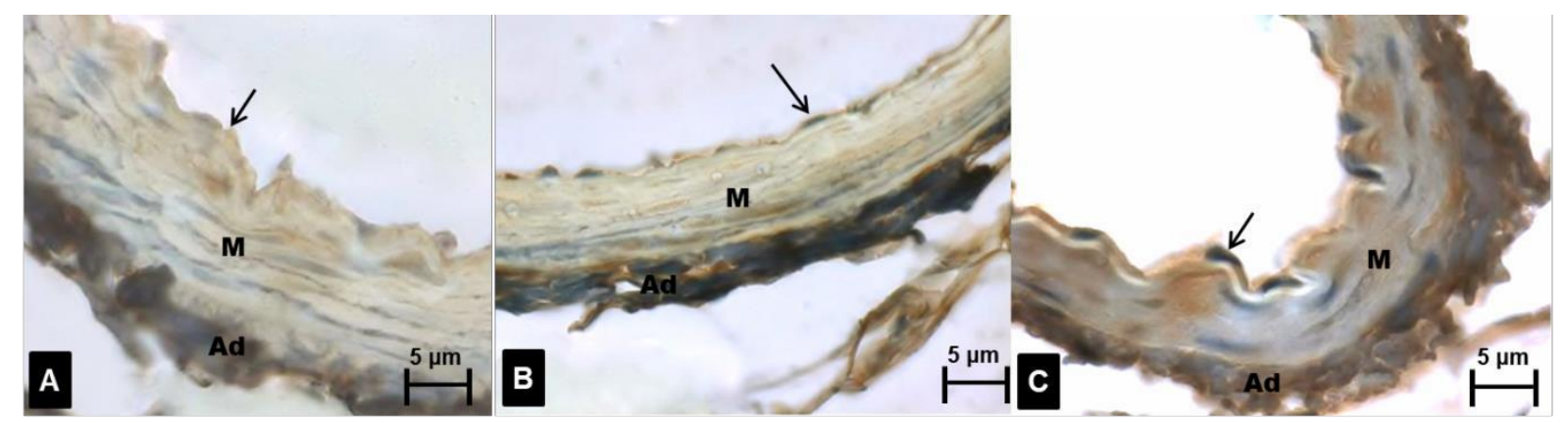

Figura 53 : Fotomicrografias representativas da imunohistoquímica para galectina 3 nas artérias mesentéricas nos grupos estudados. As setas mostram a marcação positiva (setas), aumentada nos grupos tratados com sobrecarga salina. $A=G r u p o$ Controle; $\mathrm{B}=$ Grupo Sal 2; C= Grupo Sal 12.

Chama a atenção a marcação positiva para galectina 3 observada tanto nas aortas como nas artérias mesentéricas, mostrando-se presente no endotélio, túnica média, adventícia e até mesmo no tecido perivascular. Sem dúvida alguma, esta proteína nos abre novos caminhos a serem estudados. Um ponto que também merece avaliação é a contagem de macrófagos ativados, positivos para galectina 3 e que podem nos inferir a participação numa possível resposta inflamatória. 


\section{Considerações Finais}

Todos estes dados associados ao remodelamento vascular induzido pela sobrecarga salina refletem em alterações estruturais, nas aortas relacionados com a alteração de complacência e rigidez e, nas artérias mesentéricas relacionados com a alteração de fluxo tecidual, como será descrito a seguir. A Figura 54 resume os principais resultados obtidos neste estudo.

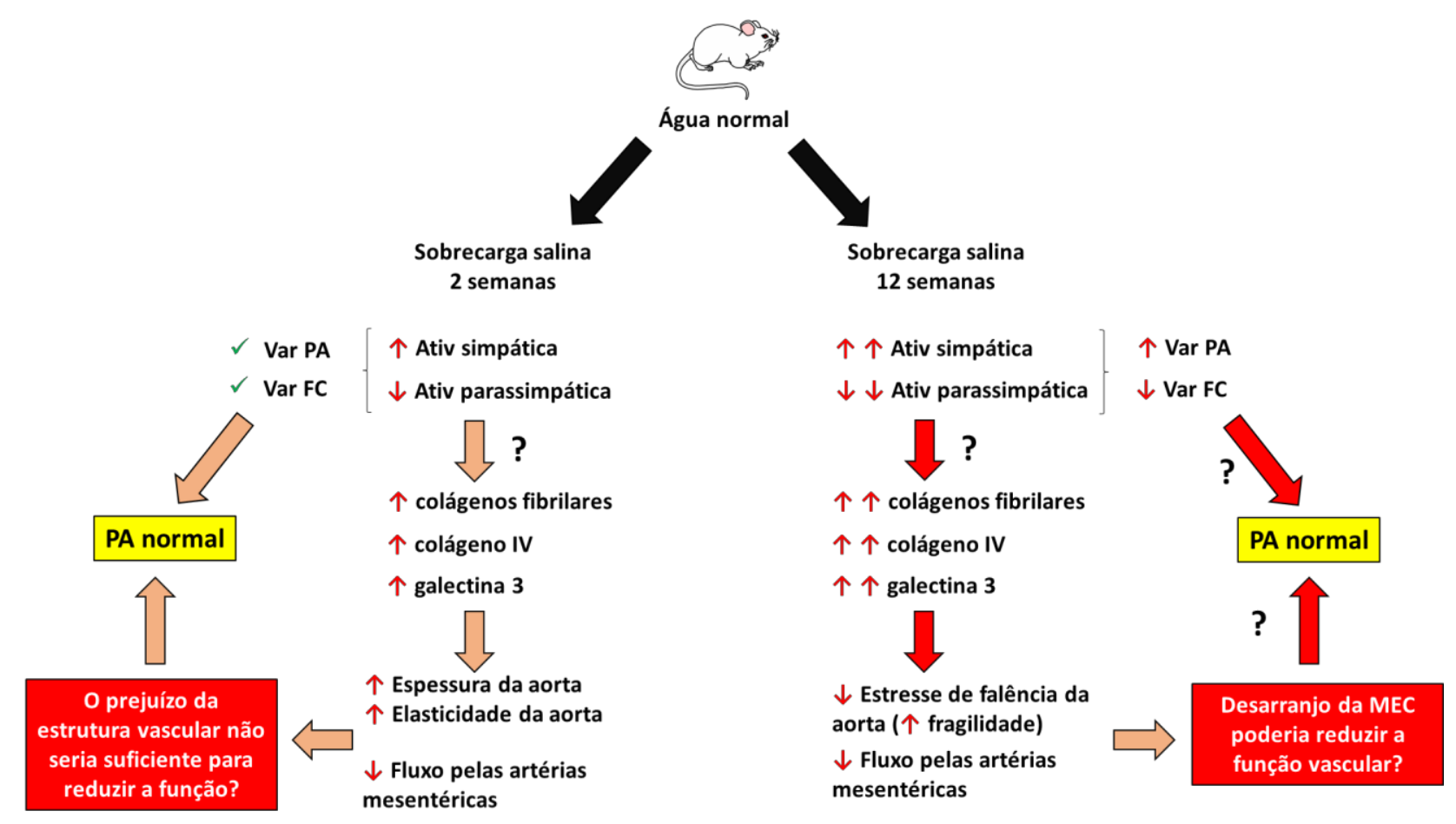

Figura 54: Resumo esquemático dos principais resultados obtidos no estudo hemodinâmico, no estudo de fluxo tecidual, no teste biomecânico da aorta, e no estudo de remodelamento vascular. Ressaltando os efeitos observados nos animais que receberam sobrecarga salina por período mais curto e crônico. Var: variabilidade; PA: pressão arterial; FC: frequência cardíaca; Baro: barorreceptores. 
Resumidamente, os resultados sugerem que a sobrecarga salina por 2 semanas leva ao aumento da atividade simpática e redução da atividade parassimpática, possivelmente interferindo na resposta estrutural vascular. Esta determinaria o remodelamento da aorta e das artérias mesentéricas, levando ao aumento da espessura da parede aórtica, bem como aumento da deposição de colágenos fibrilares e não fibrilares, bem como de galectina 3. A consequência destas alterações na aorta não parece alterar a rigidez ou resistência vascular. Além disso, a consequência destas alterações nas artérias mesentéricas se relaciona ao aumento da parede vascular e redução de fluxo tecidual. Possivelmente, a manutenção da variabilidade da PA e da FC, associada a um possível arranjo da MEC vascular não tão alterado devem ser fundamentais para garantir a função vascular e evitar a elevação da PA sistêmica.

Por outro lado, os resultados sugerem que a sobrecarga salina por 12 semanas leva ao aumento mais pronunciado da atividade simpática e à redução mais pronunciada da atividade parassimpática, possivelmente alterando a resposta estrutural vascular. Tal resposta determinaria o remodelamento da aorta e das artérias mesentéricas de forma mais marcante, levando ao grande aumento da espessura da parede aórtica, bem como ao maior aumento da deposição de colágenos fibrilares e não fibrilares, bem como de galectina 3. Assim, tais alterações na estrutura vascular impactam nas aortas, impondo grande deposição de colágenos e galectina, sugerindo um possível desarranjo na estrutura vascular. Este desarranjo pode explicar a maior fragilidade da artéria após a sobrecarga salina crônica. Nas artérias mesentéricas, a exacerbação da deposição de componentes da MEC deve estar diretamente relacionada com a redução de fluxo e alteração da função vascular. Estas modificações nas paredes arteriais parecem se relacionar ao enrijecimento de pequenas artérias que, associados ao aumento da variabilidade da PA e da FC, podem desencadear o aumento da pressão arterial sistêmica.

É de se esperar que os vasos de resistência remodelem mais precocemente se comparados aos vasos de condutância, mesmo sem a influência da PA. Trabalhos de nosso grupo já demonstraram que em camundongos machos, as artérias cardíacas sofreram remodelamento com 2 semanas de sobrecarga salina, enquanto que a aorta sofreu remodelamento significante mais tardiamente, com 12 semanas (SILVA, 2013). 
Mesmo não sendo resultados estatisticamente relevantes, não podemos ignorar a alteração de fluxo que se mostra na parede da aorta (relacionada a outra microvasculatura potencialmente alterada pela sobrecarga salina: a vasa vasorum). Talvez para os vasos que nutrem a parede da aorta, o tempo de sobrecarga salina não tenha sido suficiente para prejudicar o fluxo tecidual. Além disso, alguns trabalhos têm mostrado que a sobrecarga salina em ratos wistar (sal-resistentes) leva ao remodelamento vascular e cardíaco, com aumento de deposição de colágeno perivascular e entre fibras miocárdicas (FORECHI et al., 2015). Tais remodelamentos podem acontecer independentemente de alterações na PA (GRIGOROVA et al., 2016).

Poucos são os estudos relacionados ao remodelamento da MEC na ausência de hipertensão arterial. No entanto, se pensarmos na função dos colágenos e outros componentes da MEC, veremos que isso ajuda a explicar pelo menos em parte as alterações observadas. Estudos já demonstraram que miofibroblastos podem sintetizar colágeno IV na membrana basal para suportar a migração celular. Porém, diante de fatores estressores, a síntese de colágeno não fibrilar seria substituída pela formação de colágeno I, que é mecanicamente mais estável (MAIELLARO; TAYLOR, 2007).

Já a redução do colágeno VII pode estar envolvida no processo momentâneo em que este vaso se encontra. Não estamos falando de uma doença estabelecida, como a hipertensão arterial, mas sim analisando um momento de transição entre uma condição saudável para uma doença. Clinicamente saudável, porém que apresenta diversas alterações hemodinâmicas e teciduais na tentativa de se adequar a uma nova condição. Portanto, um colágeno responsável pela união $\mathrm{MEC} /$ célula que se apresente diminuído confirma nossos resultados de remodelamento extracelular vascular.

As principais enzimas envolvidas no remodelamento de MEC vascular são as metaloproteinases. Elas agem sobre diversas proteínas da MEC, degradando-as. Embora não tenhamos obtido alterações estatisticamente significantes no grupo Sal12, o aumento da imunomarcação pra MMP-2 nos animais tratados por 2 semanas pode ajudar a explicar o remodelamento observado. 
Desta forma, pode-se entender que a sobrecarga salina é capaz de induzir alterações mesmo em momentos bastante precoces, levando a adaptações morfofuncionais que podem ser interpretadas como um desenvolvimento de uma condição semelhante ao estado pré-hipertensivo. Certamente, este é um estudo que abre muitas portas de questionamentos e estudos futuros.

\section{Conclusões}

Considerando os resultados obtidos neste estudo e a discussão feita, podemos concluir que a sobrecarga salina, mesmo não modificando a pressão arterial média, induz:

1. alterações no controle hemodinâmico independentes de alteração na pressão arterial média, podendo ser estas caracterizadas como uma disfunção autonômica, semelhante ao observado em indivíduos hipertensos;

2. modificação no fluxo sanguíneo tecidual, que aumenta na aorta (vasa vasorum) e reduz no intestino, irrigado pelas artérias mesentéricas;

3. remodelamento na parede aórtica, possivelmente desarranjando a estrutura da MEC e levando desde rigidez em momentos precoces a fragilidade em momentos crônicos;

4. remodelamento da MEC vascular tanto em vasos elásticos como a aorta, como vasos de resistência como as artérias mesentéricas. Este remodelamento leva à reorganização das fibras colágenas (fibrilares e não fibrilares) e componentes elásticos. E esta alteração provavelmente tem participação da galectina 3. 


\title{
8. Referências Bibliográficas
}

\author{
ABBOUD FM E MD THAMES. INTERACTION OF CARDIOVASCULAR REFLEXES IN \\ CIRCULATORY CONTROL. In :(ed) Handbook of physiology \\ the cardiovascular system III, 1983. P675-753
}

ALABAMA PHARMACY ASSOCIATION | Summer 2015: Continuing EDUCATION Hypertension:The Silent Killer: Updated JNC-8 Guideline Recommendations

AMARAL SL, ZORN TM, MICHELINI LC.Exercise training normalizes wall-to-lumen ratio of the gracilis muscle arterioles and reduces pressure in spontaneously hypertensive rats. J Hypertens. 2000 Nov;18(11):1563-72.

ANTONIO F. SANJULIANI,MARCIA R. S. G. TORRES,LIVIA N. PAULA,FABIANA B. B ASSAN. Eixo renina•angiotensina•aldosterona: Bases fisiológicas e isiopatológicas

BENETOS A, LAURENT S, HOEKS AP, BOUTOUYRIE PH, SAFAR ME. Arterial alterations with aging and high blood pressure. A noninvasive study of carotid and femoral arteries. Arterioscler Thromb. 13:90-97, 1993.

BOSMAN, F.T.; STAMENKOVIC, I. Functional structure and composition of the extracellular matrix. J. Pathol. v.200, p.-423-428. 2003.

BURT DW. Evolutionary grouping of the transforming growth factor-beta superfamily. Frontiers in Neuroscience. Biochem Biophys Res Commun. 1992 Apr 30;184(2):590-5.

CAMPBELL, D.J. Critical Review of Prorenin and (Pro)renin Receptor Research. Hypertension. v.51.p.1259-1264. 2008.

CAREY RM. AT2 Receptors: Potential Therapeutic Targets for Hypertension. Am J Hypertens (2016) hpw121 J Cardiovasc Pharmacol. 2015 Mar;65(3):226-32.

CECELJA M, CHOWIENCZYK P. Role of arterial stiffness in cardiovascular disease. J R Soc Med Cardiovasc Dis 2012;1:11. DOI 10.1258/cvd.2012.012016

CECELJA M, CHOWIENCZYK P. Molecular Mechanisms of Arterial Stiffening.Pulse 2016;4:43-48

CHARKOUDIAN N, RABBITTS JA. Sympathetic neural mechanisms in human cardiovascular health and disease. Mayo Clin Proc. 2009;84:822-830.

CHERNE PN, YOUNG P. Historia del sistema renina angiotensina: grandes hombres, un gran descubrimiento.Rev Med Chile 2014;142:1210-1216

CHOI HY, PARK HC, HA SK. Salt Sensitivity and Hypertension: A Paradigm Shift from Kidney Malfunction to Vascular Endothelial Dysfunction. Electrolyte Blood Press. 2015 Jun;13(1):7-16. doi: 10.5049/EBP.2015.13.1.7. Epub 2015 Jun 30.

CHUGH G, ASGHAR M, PATKI G, BOHAT R, JAFRI F, ALLAM F, DAO AT, MOWREY C, ALKADHI K, SALIM S. A high-salt diet further impairs age-associated declines in cognitive, behavioral, and cardiovascular functions in male Fischer brown Norway rats. J Nutr. 2013 Sep;143(9):1406-13. 
CHRISTENSEN KL, MULVANY MJ. Location of resistance arteries. J Vasc Res, 38:1 12, 2001.

COLEMAN , T.G.; GUYTON, A.C. Hipertension caused by salt loading in the dog - III onset transient of cardiac outout and other circulatory variables. Circ. Res. v. 25.p. 153- 160. 1969.

COWLEY, Jr. A.W.; SKELTON, M.M.; MERRIL, D.C. Osmoregulation during higt salt intake: relative importance of drinking and vasopressin secretion. Am. J. Physio. v.20.p. R878886.1986

COWLEY, Jr. A.W.; SKELTON, M.M.; MERRIL, D.C.; QUILLEN, E.W.; SWITZER, S.J. Influence of daily sodium intake on vasopressin secretion and drinking in dogs. Am. J. Physiol. v.245.p. R860-872. 1983.

DELEON-PENNELL KY $Y^{1}$, ALTARA $R^{1}$, YABLUCHANSKIY $A^{1}$, MODESTI $A^{2}$, LINDSEY ML.The circular relationship between matrix metalloproteinase- 9 and inflammation following myocardial infarction. IUBMB Life. 2015 Aug;67(8):611-8. doi: 10.1002/iub.1408. Epub 2015 Aug 13.

CLARK DA ${ }^{1}$, COKER R.Transforming growth factor-beta (TGF-beta). Int J Biochem Cell Biol. $1998 \mathrm{Mar} ; 30(3): 293-8$.

DAVIS EC. Smooth muscle cell to elastic lamina connections in developing mouse aorta. Role in aortic medial organization. Lav Invest, 68:89-99, 1993.

DAHLY AJ, HOAGLAND KM, FLASCH AK, JHA S, LEDBETTER SR, ROMAN RJ. Antihypertensive effects of chronic anti-TGF- antibody therapy in Dahl S rats. Am J Physiol Regul Integr Comp Physiol 283: R757-R767,2002.

DANIEL C, WIEDE J, KRUTZSCH HC, RIBEIRO SM, ROBERTS DD, RPHYULLRICH JE, HUGO C. Thrombospondin-1 is a major activator of TGF-beta in fibrotic renal disease in the rat in vivo. Kidney Int 65: 459 - 468, 2004.

DAVIES PF. Flow-mediated endothelial mechanotransduction. Physiol Rev 75: 519 - 560, 1995.

D'ELIA L, GALLETTI F, STRAZZULLO P. Dietary salt intake and risk of gastric cancer. Cancer Treat Res. 2014;159:83-95. doi: 10.1007/978-3-642-38007-5_6. Review.

DE LUCA LA JR, MENANI JV, JOHNSON AK. SourceNeurobiology of Body Fluid Homeostasis: Transduction and Integration. Boca Raton (FL): CRC Press/Taylor \& Francis; 2014. Chapter 15.

DE ANGELIS, K. L. et al. Exercise training in aging: hemodynamic, metabolic, and oxidative stress evaluations. Hypertension, v. 30, n. 3 Pt 2, p. 767-71, Sep 1997.

DE ANGELIS LOBO D'AVILA, K., et al. Exercise reverses peripheral insulin resistance in trained L-NAME-hypertensive rats. Hypertension, v.34, n.4 Pt 2, p.76872. Oct, 1999

DZAU, VJ. Circulating versus local renin-angiontensin system in cardiovascular homeostasis. Circulation, v.77, n6 pt2, p.14-13, Jun, 1988.

EVANS RG1, BIE P2. Role of the kidney in the pathogenesis of hypertension: time for a neoGuytonian paradigm or a paradigm shift?. Am J Physiol Regul Integr Comp Physiol. 2016 Feb 1;310(3):R217-29. Epub 2015 Nov 18. 
FEIHL F, LIAUDET L, WAEBER B, et al.: Hypertension, a disease of the microcirculation? Hypertension, 48:1012-1017, 2006.

FENG W, YING WZ, AARON KJ, SANDERS PW.Transforming growth factor- $\beta$ mediates endothelial dysfunction in rats during high salt intake. Am J Physiol Renal Physiol. 2015 Dec 15;309(12):F1018-25.2015. Epub 2015 Oct 7.

FLORAS JS, HASSAN MO, JONES JV et al. Consequences of impaired arterial baroreflexes in essential hypertension: effets on pressor responses, plasma noradrenaline and blood pressure variability. J Hypertens 6: 525-35, 1988.

FOLKOW B. Physiolog ical aspects of primary hypertension. Physiol Rev, 62: 347-504, 1982.

FLUES, K., et al. Exercise training associated with estrogen therapy induced cardiovascular benefits after ovarian hormones deprivation. Maturitas, v.65, n.3, p.267- 71. Mar, 2010.

FITZSIMMONS, C.M.; SHANAHAN, C.M. Vascular extracellular matrix. In: LANZER, P.; TOPOL, E.J. (Eds.). Panvascular medicine. Berlin-New York: Springer.p.217-231. 2002.

FRANTZ C, STEWART KM, WEAVER VM. The extracellular matrix at a glance. J Cell Sci, 123:4195-4200, 2010.

GOUMANS MJ, TEN DIJKE P.TGF- $\beta$ Signaling in Control of Cardiovascular Function.Cold Spring Harb Perspect Biol. 2018 Feb 1;10(2). pii: a022210. doi: 10.1101/cshperspect.a022210. Review.

.GE S, FENG X, SHEN L, WEI Z, ZHU Q, SUN J. Association between Habitual Dietary Salt Intake and Risk of Gastric Cancer: A Systematic Review of Observational Studies. Gastroenterol Res Pract. 2012;2012:808120. doi: 10.1155/2012/808120. Epub 2012 Oct 22.

GEHLKEN C, SUTHAHAR N, MEIJERS WC, DE BOER RA. Galectin-3 in Heart Failure: An Update of the Last 3 Years. Heart Fail Clin. 2018 Jan;14(1):75-92. doi: 10.1016/j.hfc.2017.08.009. Review.

GIMBRONE, M. A. Vascular endothelium, hemodynamic forces, and atherogenesis. Am. J. Pathol., v. 155, p. 1-5, 1999.

GLAGOV, S. et al. Principles of vascular remodeling. In: LANZER, P.; TOPOL, E.J. (Eds.) Panvascular medicine. Berlin - New York: Springer. p. 232-241. 2002.

GRIGOROVA YN, JUHASZ O, ZERNETKINA V, FISHBEIN KW, LAKATTA EG, FEDOROVA OV, BAGROV AY. Aortic Fibrosis, Induced by High Salt Intake in the Absence of Hypertensive Response, Is Reduced by a Monoclonal Antibody to Marinobufagenin. Am J Hypertens. 2015 Sep 7. pii: hpv155.

GUYTON, A.C.; COLEMAN, T.G.; BOWER, J.D.; GRANGER, H.J. Circulatory control in hypertension, Circ. Res. v. XXVI e XXVII.p. II135-II147. 1970.

GARCIA-CARDEÑA G, COMANDER J, ANDERSON KR, BLACKMAN BR, GIMBRONE MA JR. Biomechanical activation of vascular endothelium as a determinant of its functional phenotype. Proc Natl Acad Sci USA 98: 4478 - 4485, 2001 
GRASSI G, BRAMBILLA G, PIZZALLA DP, SERAVALLE G. Baroreflex Activation Therapy in Congestive Heart Failure: Novel Findings and Future Insights. Curr Hypertens Rep. 2016 Aug;18(8):60.

GUYTON AC. Arterial pressure and hypertension. Philadelphia, Saunders, 1980. GUYTONAC.Long-term arterial pressure control: an analysis from animal experirnents and computer and graphic rnodels. Am J Physiol Regu/atory Integrative Comp Physiol, 259: R865-77, 1990

GUZZETTI S, PICCALUGA E, CASATI R, CERUTTI S, LOMBARDI F, PAGANI M, MALLIANI A. Sympathetic predominance in essential hypertension: a study employing spectral analysis of heart rate variability. J Hypertens. 1988;6:711- 717.

GRAY C, HARRISON CJ, SEGOVIA SA, REYNOLDS CM, VICKERS MH. Maternal salt and fat intake causes hypertension and sustained endothelial dysfunction in fetal, weanling and adult male resistance vessels. Sci Rep. 2015 May 8;5:9753. doi: 10.1038/srep09753.

HE, F.J.; CAMPBELL, N.R.C.; MACGREGOR, G.A. Reducing salt intake to prevent hypertension and cardiovascular disease. Rev. Panam. Salud Publica, v. 32, p. 293300. 2012.

HYNES RO. The extracellular matrix: not just pretty fibrils. Science, 326:1216-9, 2009.

INTERSALT COOPERATIVE RESEARCH GROUP. Intersalt: an international study of electrolyte excretion and blood pressure. Results for 24 hour urinary sodium and potassium excretion. BMJ. v.297. p.319-28. 1988

IRIGOYEN MC, DE ANGELIS K, SANTOS F,DARTORA D, RODRIGUES B, CONSOLIMCOLOMBO FM. Hypertension, Blood Pressure Variability, and Target Organ Lesion. Current Hypertension Reports. April 2016.

IRIGOYEN MC, KRIEGER EM. Baroreflex control of sympathetic activity in experimental hypertension. Braz J Med Biol Res. 1998 Sep;31(9):1213-20. Review.

IRIGOYEN MC, CONSOLIM-COLOMBO FM, KRIEGER EM. Controle cardiovascular: regulação reflexa e papel do sistema nervoso simpático. Rev Bras Hipertens 8: 55-62, 2001

IRIGOYEN MC, MOREIRA ED, CESTARI IA, KRIEGER EM. The relationship between renal sympathetic nerve activity and arterial pressure after selective denervation of baroreceptors and chemoreceptors. Braz J Med Biol Res 1991; 24:219-22.

IRIGOYEN MC, MOREIRA ED, IDA F, PIRES M, CESTARI IA, KRIEGER EM. Changes of renal sympathetic activity in acute and chronic conscious sinoaortic denervated rats. Hypertension 1995; 26(6 Pt 2):1111-6.

JAMALI HK, WAQAR F, GERSON MC. Cardiac autonomic innervation. J Nucl Cardiol. 2016 Nov 14

JUNQUEIRA, L.C.U.; CARNEIRO, J. Histologia Básica. 10ed. Rio de Jneiro: GuanabaraKoogan, 2004.488p. 
JIANG F., YANG J., ZHANG Y., DONG M., WANG S., ZHANG Q., et al. Angiotensinconverting enzyme 2 and angiotensin 1-7: novel therapeutic targets. Nat. Rev. Cardiol. 11 413-426. 10.1038/nrcardio.2014.59 (2014).

KHALIL N11.TGF-beta: from latent to active. Microbes Infect. 1999 Dec;1(15):1255-63

KELLEHER CM, MCLEAN SE, MECHAM RP. Vascular ex-tracellular matrix and aortic development. Curr Top Dev Biol, 62: 153-88, 2004.

LACCHINI S, HEIMANN AS, EVANGELISTA FS, CARDOSO L, SILVA GJ, KRIEGER JE. Cuffinduced vascular intima thickening is influenced by titration of the Ace gene in mice. Physiol Genomics. 2009 May 13;37(3):225-30.

LICHTMAN MK, OTERO-VINAS M, FALANGA V.Transforming growth factor beta (TGF- $\beta$ ) isoforms in wound healing and fibrosis. Wound Repair Regen. 2016 Mar;24(2):215- 22. doi: 10.1111/wrr.12398. Epub 2016 Mar 2. Review

LI DY, BROOKE B, DAVIS EC, MECHAM RP, SORENSEN LK, BOAK BB, EICHWALD E, KEATING MT. Elastin is an essential determinant of arterial morphogenesis. Nature. 1998 May 21;393(6682):276-80.

LIMA CT, SILVA JC, VIEGAS KA, OLIVEIRA TC, LIMA RS, SOUZA LE, ARAGÃO D, CASARINI DE, IRIGOYEN MC, LACCHINI S. Increase in Vascular Injury of Sodium Overloaded Mice May be Related to Vascular Angiotensin Modulation. PLoS One. 2015 Jun 1;10(6):e0128141.

LILES, J. H. \& P. A. FLECKNELL. The use of non-steroidal anti-inflammatory drugs for the relief of pain in laboratory rodents and rabbits. Lab Anim, v.26, n.4, p.241-55. Oct, 1992

LIU HB, ZHANG J, SUN YY, LI XY, JIANG S, LIU MY, SHI J, SONG BL, ZHAO D, MA HP, ZHANG ZR.Dietary salt regulates epithelial sodium channels in rat endothelial cells: adaptation of vasculature to salt. Br J Pharmacol. 2015 Dec;172(23):5634-46. Epub 2015 Jun 26.

McCAWLEY, L.J.; MATRISIAN, L.M. Matriz metalloproteinases: they're not just for matrix anymore. Curr.Opin. Cell. Biol. v. 13. p. 534-540. 2011.

MATAVELLI LC, ZHOU X, VARAGIC J, et al. Salt loading produces severe renal hemodynamicdysfunction independent of arterial pressure in spontaneously hypertensive rats. Am J Physiol Heart Circ Physiol 2007; 292:H814-H819.

MATAVELLI LC1, SIRAGY HM. AT2 receptor activities and pathophysiological implications. J Vasc Res 2007; 44:382- 390.

MICHELINI LC. Regulação neuro-humoral da pressão arterial. In (ed). Fisiologia, 1999. MENETON, P.; JEUNEMAITRE, X.; DE WANDENER, H. E.; et al. Links between dietary salt intake, renal salt handling, blood pressure and cardiovascular diseases. Physiology Rev.v. 85, p.679-715. 2005.

MOTT, J.D.; WERB, Z. Regulation of matrix biology by matrix metalloproteinases. Cur.Opin. Cell. Biol. v. 15. P.558-564.2004 
MÜLLER, D.N.; FISCHLI, W.;CLOZEL, J-P.; HILGERS, K.F.; BOHLENDER, J.; MÉNARD, J.; BUSJAHN, A.; GANTEN, D.; LUFT, F.C. Local Angiotensin II Generation in the Rat Heart: Role of Renin Uptake. Circ Res.v.82.p13-20.1998

O'DONNELL M, MENTE A, YUSUF S. Sodium Intake and Cardiovascular Health.Circ. Res. 2015;116:1046-1057

PARATI G, OCHOA JE., GRZEGORZ B. Blood Pressure Variability, Cardiovascular Risk, and Risk for Renal Disease Progression. Current Hypertension Reports.October 2012, Volume 14, Issue 5, pp 421-431

PASSOS-SILVA D. G., BRANDAN E., SANTOS R. A. Angiotensins as therapeutic targets beyond heart disease. Trends Pharmacol. Sci. 36 310-320. 10.1016/j.tips.2015.03.001(2015).

PITRA S, FENG Y, STERN JE. Mechanisms underlying prorenin actions on hypothalamic neurons implicated in cardiometabolic control. Mol Metab. 2016 Aug 4;5(10):858-68. doi: 10.1016/j.molmet.2016.07.010. eCollection 2016.

PLENZ, G. Vascular collagens: spotlight on the role of type VIII collagen in atherogenesis. Atherosclerosis. v. 166.p.1-11. 2003.

RAGHAVAN ML, WEBSTER MW, VORP DA. Ex Vivo Biomechanical Behavior of Abdominal Aortic Aneurysm: Assessment Using a New Mathematical Model .Annals of Biomedical Engineering, Vol. 24, pp. 573-582, 1996

REIS DJ. The brain and hypertension: reflections on 35 years of inquiry into the neurobiology of the circulation. Circulation.1984;70(5 Pt 2):III31-45

SALMAN IM. Major Autonomic Neuroregulatory Pathways Underlying Short- and Long- Term Control of Cardiovascular Function. Curr Hypertens Rep. 2016 Mar;18(3):18.

SHEPERD JT. Increased systemic vascular resistance and prymary hypertension: the expanding complex. J Hypertens 8 (Suppl 7): S15-S27, 1990

SERAVALLI P, DE OLIVEIRA IB, ZAGO BC, DE CASTRO I, VERAS MM, ALVESRODRIGUES EN, HEIMANN JC.High and Low Salt Intake during Pregnancy: Impact on Cardiac and Renal Structure in Newborns. PLoS One. 2016 Aug 25;11(8):e0161598.eCollection 2016.

SHIMOURA CG, LINCEVICIUS GS, NISHI EE, GIRARDI AC, SIMON KA, BERGAMASCHI CT, CAMPOS RR. Increased Dietary Salt Changes Baroreceptor Sensitivity and Intrarenal Renin-Angiotensin System in Goldblatt Hypertension. Am J Hypertens. 2017 Jan;30(1):28-36. Epub 2016 Sep 14.

SAKS, F.M. et al. Effects on blood pressure of reduced dietary sodium and the dietary approaches to stop hypertension (DASH) diet. N. Engl. J. Med., v. 344.n. 1, p.3-10. 2001.

SCHIFFRIN, E.L. Vascular mineralocorticoid receptor regulate blood pressure effects on myogenic tone and role in aging. Circulation Research. v.112, p.415-417. 2013.

SEALEY, J.E.Plasma Renin Activity and Plasma Renin Assays. Clin. Chem. v.37/10B.p.18111819. 1991. 
SILVA, JCS. Efeito da sobrecarga salina no remodelamento vascular. Dissertação de mestrado. Universidade de São Paulo. São Paulo.2013.

SIMMONDS SS, LAY J, STOCKER SD. Dietary salt intake exaggerates sympathetic reflexes and increases blood pressure variability in normotensiverats. Hypertension. 2014 Sep;64(3):583-9.

SONG,S.H.; ROACH, M.R. A morphological comparison on aortic elastin from five species as seen with the scanning electron microscope. Acta Anat. v. 123.p. 45-50. 1985.

SOROTA S.The sympathetic nervous system as a target for the treatment of hypertension and cardiometabolic diseases. J Cardiovasc Pharmacol. 2014 May;63(5):466-76. doi: 10.1097/FJC.0000000000000064

SOUZA, S. B., et al. Role of exercise training in cardiovascular autonomic dysfunction and mortality in diabetic ovariectomized rats. Hypertension, v.50, n.4, p.786-91. Oct, 200

STAMENKOVIC, I. Extracellular matrix remodeling: the role of matrix metalloproteinases. J Pathol. v. 200, p.448-464. 2003.

STEVENS SL, WOOD S, KOSHIARIS C, LAW K, GLASZIOU P, STEVENS RJ, MCMANUS RJ Blood pressure variability and cardiovascular disease: systematic review and metaanalysis.

STHBENS, W.E.Structural and architectural changes during arterial development and the role of hemodynamics. Acta. Anat. v.157.p.261-274.1996.

TOBIAN L, HANLON S. High sodium chloride diets injure arteries and raise mortality without changing blood pressure. Hypertension 15: 900 -903, 1990

THIJSSEN VL ${ }^{1}$, HEUSSCHEN R ${ }^{2}$, CAERS $\mathrm{J}^{2}$, GRIFFIOEN AW G Galectin expression in cancer diagnosis and prognosis: A systematic review. Biochim Biophys Acta. 2015 Apr;1855(2):235-47. doi: 10.1016/j.bbcan.2015.03.003. Epub 2015 Mar 25.

VICTOR RG, MARK AL. The sympathetic nervous system in human hypertension. In: Laragh $\mathrm{JH}$, Brenner BM, eds. Hypertension: Pathophysiology, Diagnosis and Management, 2 ed. New York: Raven Press Ltd., 1995; pp.755-73

VIEGAS, K.A.S.; LACCHINI, S. Injúria vascular e reestenose: In: Krieger, J.E. (Ed.). Bases moleculares das doenças cardiovasculares: a integração entre a pesquisa e a prática clínica. São Paulo. Atheneu, 2008.p.415-432.

WORLD HEALTH ORGANIZATION, WHO, A Global Brief On Hypertension. Can be ccessed from: $\quad$ http://www.who.int/cardiovascular diseases/publications/global brief hypertension/en/, 2013

YU HCM, BURRELL LM, BLACK MJ, WU LL, DILLEY RJ, COOPER ME, JOHNSTON CI. Salt induces myocardial and renal fibrosis in normotensive and hypertensive rats. Circulation 98: 2621-2628, 1998. 
YAMAMOTO T, NAKAMURA T, NOBLE NA, RUOSLAHTI E, BORDER WA. Expression of transforming growth factor is elevated in human and experimental diabetic nephropathy. Proc Natl Acad Sci USA 90: 1814 -1818, 1993.

YAMAMOTO T, NOBLE NA, MILLER DE, BORDER WA. Sustained expression. of TGF-beta1 underlies development of progressive kidney fibrosis. Kidney Int 45: $916-927,1994$

YU HC, BURRELL LM, BLACK MJ, et al. Salt induces myocardial and renal fibrosis in normotensive and hypertensive rats. Circulation 1998; 98:2621- 2628.

ZIYADEH FN, HOFFMAN BB, HAN DC, IGLESIAS-DE LA CRUZ MC, HONG SW, ISONO M, CHEN S, MCGOWAN TA, SHARMA K. Long-term prevention of renal insufficiency, excess matrix gene expression, and glomerular mesangial matrix expansion by treatment with monoclonal anti-transforming growth factor-beta antibody in $\mathrm{db} / \mathrm{db}$ diabetic mice. Proc Natl Acad Sci USA 97: 8015- 8020, 2000.

NISHIJO N, SUGIYAMA F, KIMOTOK, TANIGUCHI K, MURAKAMI K, SUZUKI S, FUKAMIZU A, YAGAMI K. Salt-sensitive aortic aneurysm and rupture in hypertensive transgenic mice that overproduce angiotensin II. Lab Invest. 1998 Sep;78(9):1059-66.

YABLUCHANSKIY A ${ }^{1}$, MA Y, IYER RP, HALL ME, LINDSEY ML. Matrix metalloproteinase-9: Many shades of function in cardiovascular disease. Physiology (Bethesda). 2013 Nov;28(6):391-403. doi: 10.1152/physiol.00029.2013. 


\section{ANEXOS}

A seguir, são apresentados dados complementares obtidos neste estudo

ANEXO I - cálculo do peso normalizado pelo comprimento naso-anal em coração, pulmões, rins, glândulas adrenais, fígado e pâncreas

\begin{tabular}{|c|c|c|c|}
\hline Órgãos & Controle & Sal-2 & Sal-12 \\
\hline Coração (g/cm) & $0,063 \pm 0,003$ & $0,065 \pm 0,004$ & $0,067 \pm 0,005$ \\
\hline Pulmões $\mathbf{( g / c m )}$ & $0,103 \pm 0,021$ & $0,110 \pm 0,026$ & $0,107 \pm 0,016$ \\
\hline Rins $\mathbf{( g / c m ) ~}$ & $0,168 \pm 0,009$ & $0,167 \pm 0,010$ & $0,162 \pm 0,036$ \\
\hline Adrenais $\mathbf{( g / c m )}$ & $0,004 \pm 0,001$ & $0,005 \pm 0,001$ & $0,004 \pm 0,001$ \\
\hline Fígado $\mathbf{( g / c m )}$ & $0,677 \pm 0,131$ & $0,672 \pm 0,046$ & $0,695 \pm 0,073$ \\
\hline Pâncreas $\mathbf{( g / c m})$ & $0,074 \pm 0,020$ & $0,060 \pm 0,015$ & $0,066 \pm 0,14$ \\
\hline
\end{tabular}


Fluxo tecidual - Pulmão D

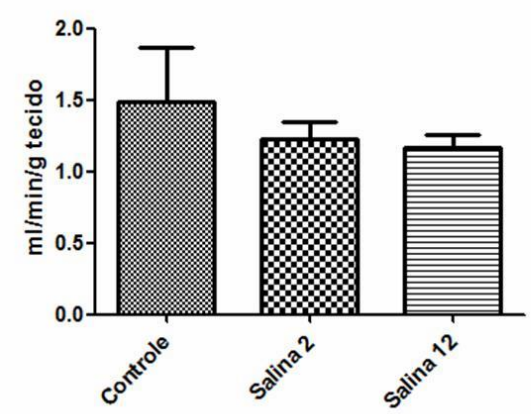

Fluxo tecidual - Pulmão E
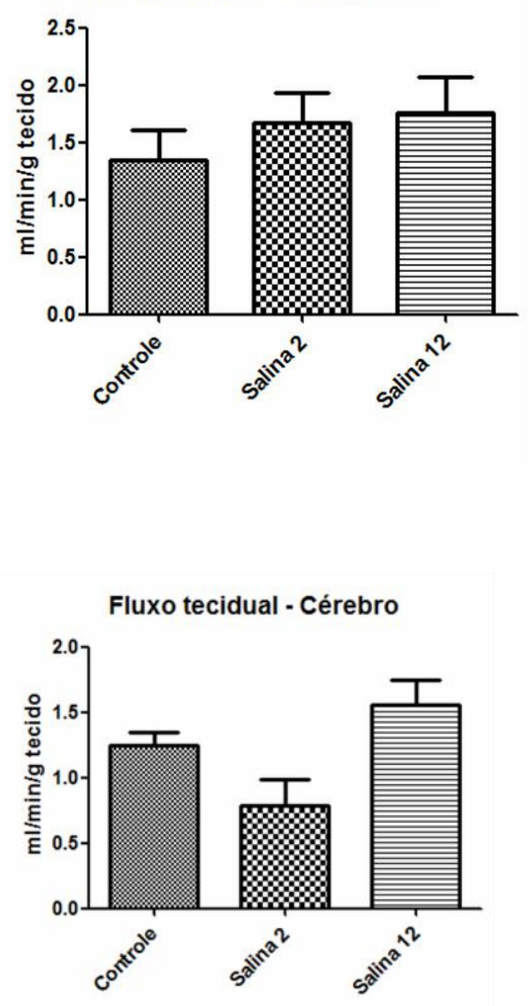

Fluxo tecidual - Rim D

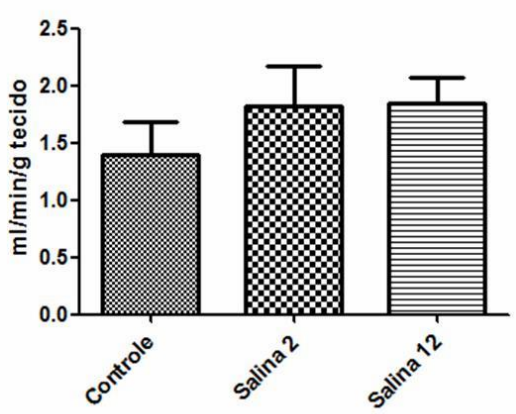

Fluxo tecidual - Rim E

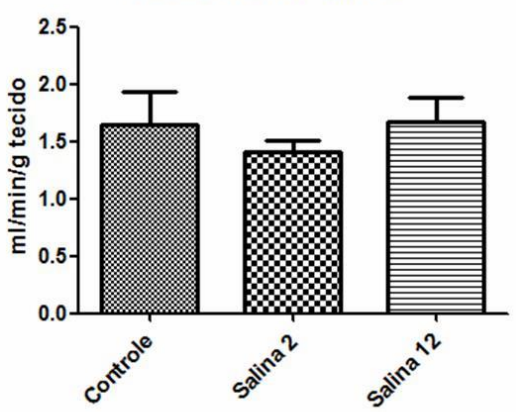

Fluxo tecidual - Gastrocnêmio

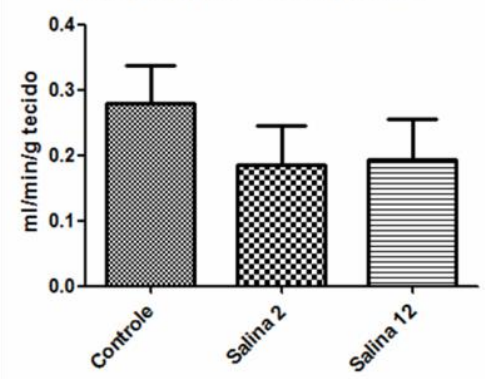


ANEXO III - Atividade da MMP 2 Avaliada por zimografia em coração, artéria femoral e artéria carótida
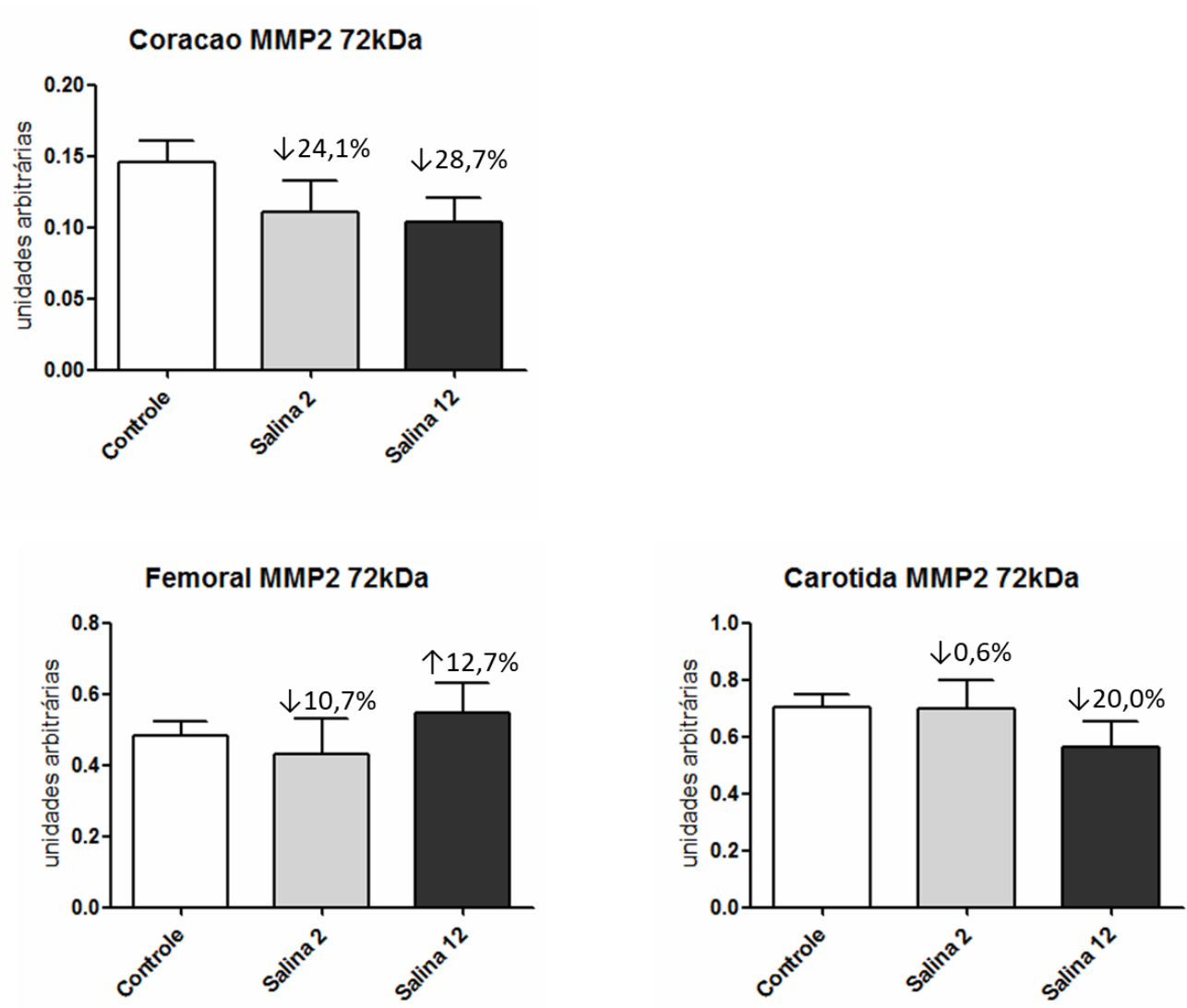